\title{
Geology of the Silsilah Ring Complex and Associated Tin Mineralization, Kingdom of Saudi Arabia
}

U.S. GEOLOGICAL SURVEY PROFESSIONAL PAPER 1459

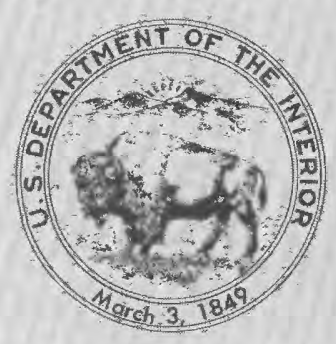





\section{Geology of the Silsilah Ring Complex and Associated Tin Mineralization, Kingdom of Saudi Arabia}

By EDWARD A. DU BRAY

U. S. GEOLOGIGAL SUR VEY PROFES IONAL PAPER 1459

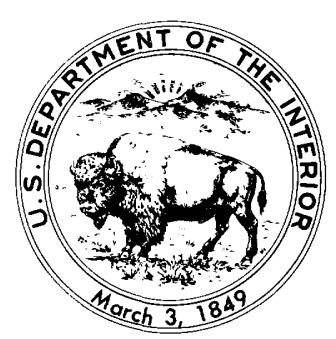




\section{DEPARTMENT OF THE INTERIOR}

DONALD PAUL HODEL, Secretary

\section{U. S. GEOLOGICAL SURVEY}

Dallas L. Peck, Director

\section{Library of Congress Cataloging-in-Publication Data}

Du Bray, E. A.

Geology of the Silsilah ring complex and associated tin mineralization, Kingdom of Saudi Arabia.

(Professional paper ; 1459)

Bibliography: $\mathrm{p}$.

Supt. of Docs. no.: I 19.16:1459

1. Intrusions (Geology)-Saudi Arabia. 2. Cassiterite-Saudi Arabia. 3. Tin ores-Saudi Arabia. 4. Granites-Saudi Arabia. 5. Geology-Saudi Arabia. I. Title. II. Series: Professional paper (Geological Survey (U.S.)) ; no. 1459.

QE611.5.S33D8 1988 552'.0953'8

$86-600340$

For sale by the Books and Open-File Reports Section, U.S. Geological Survey, Federal Center, Box 25425, Denver, CO 80225 


\section{CONTENTS}

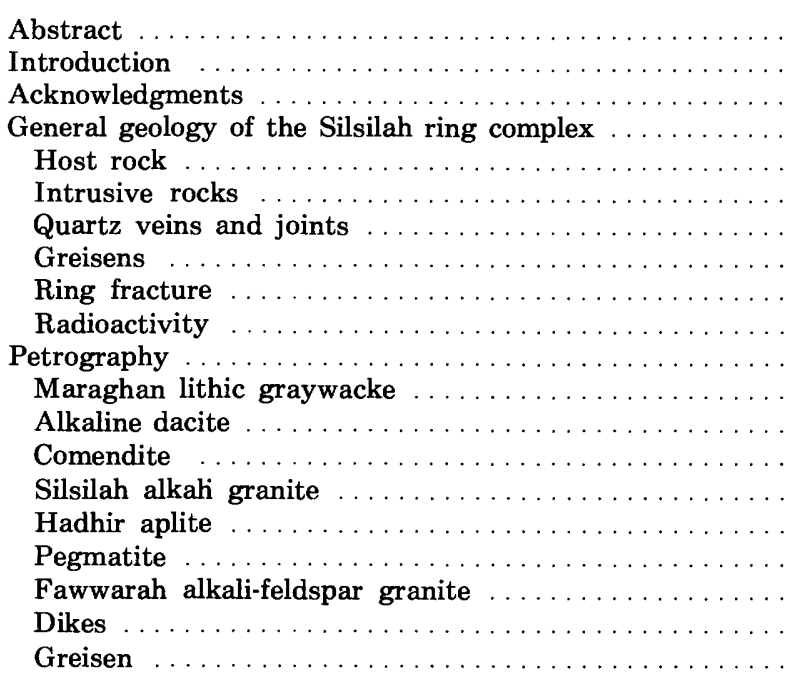

\begin{tabular}{|c|c|c|}
\hline age & & Page \\
\hline 1 & Geochemistry & 18 \\
\hline 1 & Analytical methods $\ldots \ldots$ & 18 \\
\hline 2 & Maraghan lithic graywacke & 19 \\
\hline 2 & Silsilah ring complex $\ldots \ldots$ & 19 \\
\hline 4 & Major elements ... & 19 \\
\hline 6 & Trace elements & 23 \\
\hline 7 & arth elements $\ldots \ldots \ldots \ldots \ldots \ldots \ldots \ldots \ldots$ & 24 \\
\hline 8 & Oxygen isotopes $\ldots \ldots \ldots \ldots \ldots \ldots \ldots \ldots \ldots$ & 26 \\
\hline 8 & Mineral chemistry & 26 \\
\hline 10 & Lead isotopes & 28 \\
\hline 10 & Mineralized rocks & 30 \\
\hline 11 & 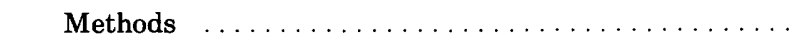 & 30 \\
\hline 12 & Results for intensely mineralized greisens $\ldots \ldots \ldots \ldots$ & 33 \\
\hline $\begin{array}{l}12 \\
15\end{array}$ & Results for other mineralized areas $\ldots \ldots \ldots \ldots \ldots$ & 36 \\
\hline 16 & sis of the igneous rocks $\ldots \ldots \ldots \ldots \ldots \ldots$ & 39 \\
\hline 10 & Petrogenesis of the mineralized rocks $\ldots \ldots \ldots \ldots \ldots$ & 44 \\
\hline 16 & d recommendations & 45 \\
\hline 17 & References cited & 46 \\
\hline
\end{tabular}

\section{ILLUSTRATIONS}

[Plates are in pocket]

Plates 1. Geologic map of the Silsilah ring complex

2. Geologic map of the southwestern part of the Silsilah ring complex

3. Geologic map of the intensely mineralized greisens in the southwestern part of the Silsilah ring complex

Figures 1. Index map of western Saudi Arabia showing the location of the Silsilah ring complex $\ldots \ldots \ldots \ldots \ldots \ldots \ldots$

2. Photomosaic showing the Silsilah ring complex

3. Photograph showing the sill-like Hadhir aplite overlying the Fawwarah alkali-feldspar granite $\ldots \ldots \ldots \ldots \ldots$

4. Photograph showing contact relations between the Silsilah alkali granite, Hadhir aplite, and Fawwarah alkali-feldspar

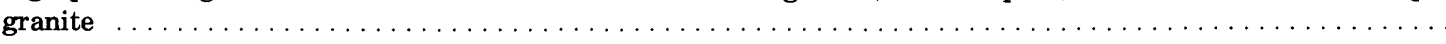

5. Photograph showing coarse-grained, quartz-potassium feldspar pegmatite $\ldots \ldots \ldots \ldots \ldots \ldots \ldots \ldots \ldots$

6. Photograph showing wolframite in the large quartz vein that transects the north end of the Fawwarah alkali-feldspar

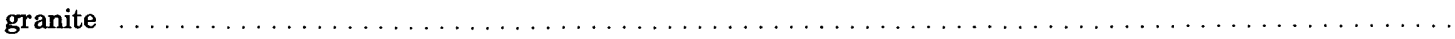

7. Photograph showing an aerial view of the intensely mineralized southern greisen $\ldots \ldots \ldots \ldots \ldots \ldots \ldots$ 
FIGURES 8. Photograph showing the contact between quartz-cassiterite-topaz greisen and a podlike accumulation of cassiterite on

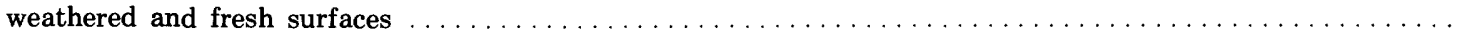

9. Map showing total-count radioactivity at sample sites in the Fawwarah alkali-feldspar granite $\ldots \ldots \ldots \ldots \ldots$

10. Photomicrographs of the alkaline dacite showing the intergranular texture of plagioclase and opaque oxides that characterizes this rock

11. Photomicrographs of the comendite showing the micrographic, porphyritic, and spherulitic textures that characterize this rock

12. Photomicrographs of the Silsilah alkali granite showing the hypidiomorphic granular and porphyritic textures that typify the unit

13. Ternary quartz-potassium feldspar-plagioclase diagram showing the modal composition of the Silsilah alkali granite

14. Photomicrographs of the Hadhir aplite showing the fine-grained allotriomorphic granular intergrowth of quartz and the feldspars

15. Ternary quartz-potassium feldspar-plagioclase diagram showing the modal composition of the Hadhir aplite .....

16. Photomicrographs of the Fawwarah alkali-feldspar granite showing the medium-grained allotriomorphic granular intergrowth of quartz and the feldspars

17. Ternary quartz-potassium feldspar-plagioclase diagram showing the modal composition of the Fawwarah alkali-feldspar granite and the proto-Fawwarah alkali-feldspar granite

18. Photomicrographs of incompletely greisenized Fawwarah alkali-feldspar granite showing inequigranular, medium-grained, allotriomorphic granular intergrowth of quartz, zinnwaldite, and minor topaz

19. Photomicrographs of completely greisenized Fawwarah alkali-feldspar granite showing inequigranular, medium-grained, allotriomorphic granular intergrowth of quartz, topaz, and strongly colored cassiterite $\ldots \ldots \ldots \ldots \ldots \ldots$

20. Plot of normative color index versus normative plagioclase composition for three samples of the Maraghan lithic graywacke

21. Chondrite-normalized rare-earth-element patterns for three samples of the Maraghan lithic graywacke ..........................

22. Harker variation diagrams showing the chemical variation exhibited by rocks of the Silsilah ring complex ......

23. Ternary alkali-iron-magnesium diagram for samples of the Silsilah $\operatorname{ring}$ complex $\ldots \ldots \ldots \ldots \ldots \ldots \ldots \ldots$

24. Plot of normative color index versus normative plagioclase composition for four samples of the alkaline dacite ...

25. Normative quartz, albite, and orthoclase ternary diagram showing the composition of samples from the Silsilah ring complex

26. Ternary diagram showing normative anorthite, albite, and orthoclase contents of samples from the Silsilah ring complex

27. Ternary rubidium-strontium-potassium diagram for samples of the Silsilah ring complex $\ldots \ldots \ldots \ldots \ldots \ldots$

28. Chondrite-normalized rare-earth-element patterns for rocks of the Silsilah ring complex $\ldots \ldots \ldots \ldots \ldots \ldots$

29. Plot showing the composition of sodium-bearing amphiboles from the Silsilah ring complex in terms of atoms of calcium

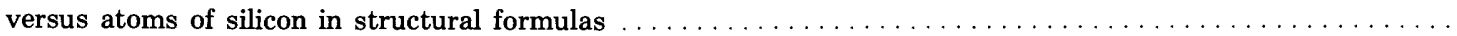

30. Concordia diagram of isotopic data for zircon from the Fawwarah alkali-feldspar granite $\ldots \ldots \ldots \ldots \ldots \ldots$

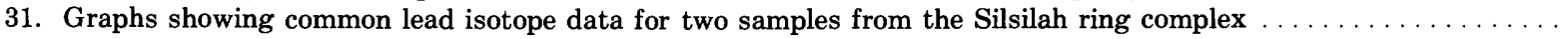

32. Maps showing the distribution of single elements in samples of the intensely mineralized greisens $\ldots \ldots \ldots \ldots \ldots$

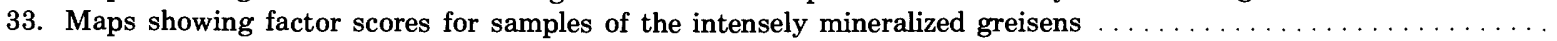

34. Index map showing the location of intensely mineralized greisens and other mineralized areas

35. Plot showing the distribution of ab between coexisting plagioclase and potassium feldspar in four samples of the Fawwarah alkali-feldspar granite

\section{TABLES}

TABLES 1. Major-element analyses and CIPW normative compositions for intrusive rocks of the Silsilah ring complex .....

2. Trace- and rare-earth-element analyses for intrusive rocks of the Silsilah ring complex $\ldots \ldots \ldots \ldots \ldots \ldots \ldots$

3. Major- and trace-element analyses and CIPW normative compositions for samples of the Maraghan lithic graywacke

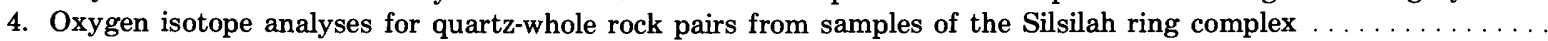

5. Structural formulas for feldspars in samples of the Fawwarah alkali-feldspar granite $\ldots \ldots \ldots \ldots \ldots \ldots$

6. Structural formulas for perthite in samples of the Silsilah alkali granite $\ldots \ldots \ldots \ldots \ldots \ldots \ldots \ldots \ldots$

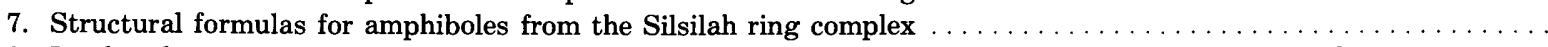

8. Lead and uranium-lead isotopic data for mineral separates from samples of the Silsilah ring complex .........

9. Elemental means and standard deviations for 68 samples collected from the two intensely mineralized greisens in the Silsilah ring complex

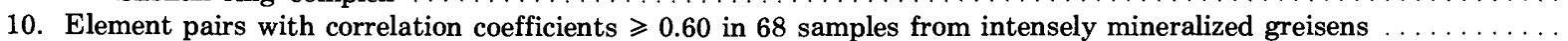

11. Components of the factors in the five-factor model for samples of the two intensely mineralized greisens .......

12. Geochemical summary for samples collected from other mineralized areas within the southwest part of the Silsilah ring complex 


\title{
GEOLOGY OF THE SILSILAH RING COMPLEX AND ASSOCIATED TIN MINERALIZATION, KINGDOM OF SAUDI ARABIA
}

\author{
By EDWARD A. DU BRAY
}

ABSTRACT

\begin{abstract}
A significant tin deposit has been identified in the northeast part of the Late Proterozoic Arabian Shield. Cassiterite-topaz-quartz greisens are distributed over $16 \mathrm{~km}^{2}$ in flat-topped cupolas of a highly evolved, zinnwaldite-bearing alkali-feldspar granite which composes part of the Silsilah ring complex (lat. $26^{\circ} 06^{\prime} \mathrm{N}$., long. $42^{\circ} 40^{\prime} \mathrm{E}$.). The alkali-feldspar granite ( $587 \mathrm{Ma}$ old) is overlain by a carapace of aplite and pegmatite. The carapace acted as an impermeable boundary, beneath which aqueous fluids accumulated and caused greisenization of the alkali-feldspar granite and deposition of disseminated cassiterite. Subsequently emplaced quartz-wolframite veins cut the alkali-feldspar granite and the aplite-pegmatite carapace.

The remainder of the Silsilah ring complex is composed of peralkaline granite, its hypabyssal equivalent, and alkaline dacite. The occurrence of alkaline dacite, peralkaline granite, and alkali-feldspar granite (oldest to youngest) in a single ring fracture suggests that these rocks form a single differentiation series. Major-, trace-, and rare-earth-element data support this hypothesis. The alkaline dacite evolved to the peralkaline granite by fractionation of sodic plagioclase, apatite, and Fe-Ti oxides. The peralkaline granite continued differentiation by fractionation of alkali feldspar, Na-pyriboles, and zircon. This process yielded the peraluminous composition; incompatible trace element enrichment; and flat, rare-earth-element patterns with large, negative europium anomalies that are characteristic of the alkali-feldspar granite. This unusual differentiation trend may be typical of other, highly evolved intrusive suites in the Arabian Shield which may have associated, yet undiscovered, tin-tungsten deposits.
\end{abstract}

\section{INTRODUCTION}

Geologic investigations conducted throughout the world have identified a group of petrologically similar granitoid rocks, known variously as $S$-type (Chappell and White, 1974), $A$-type (Collins and others, 1982), ilmenite series (Ishihara, 1977), and metallogenically specialized (Tischendorf, 1977). These rocks are characterized by highly evolved major-element compositions and incompatible trace-element enrichment, are peraluminous, may contain an aluminum-rich silicate such as muscovite, and are commonly associated with deposits of tin, tungsten, and other rare metals.

Mineral-exploration programs conducted in Saudi Arabia have demonstrated that rocks of this type occur within the Precambrian Arabian Shield (Elliott, 1980; Stoeser and Elliott, 1980; du Bray and others, 1982; du Bray, 1983a). However, mineral deposits have not been found associated with these rocks until recently. The discovery of a small, wolframite-bearing quartz vein stockwork at Baid al Jimalah in the northeast part of the Arabian Shield (Cole and others, 1981) and the recognition that the level of erosion throughout this area is probably less than in most other parts of the Arabian Shield (Whitney, 1983) indicated that this region has high favorability for deposits of tin, tungsten, and other rare-metal deposits associated with highly evolved granitoid rocks.

A reconnaissance geochemical survey was conducted throughout the northeastern Arabian Shield during the late 1970's. Unpublished data for rock and pan concentrates of wadi sediment collected during this study indicate that distinctive geochemical anomalies are associated with some of the plutonic rocks in this area (D. B. Stoeser, oral commun., 1980). A subsequently conducted, systematic wadi sediment sampling program better defined these geochemical anomalies (Allen and others, 1983) and helped identify additional anomalies.

Results of the systematic geochemical survey indicated that the Silsilah ring complex (fig. 1) is the locus of a distinctive geochemical anomaly. Sediment samples collected from wadis draining the complex contained highly anomalous concentrations of beryllium, niobium, lead, and tin in various combinations. While mapping the geology of the Jabal as Silsilah quadrangle, du Bray (1983b) identified the Fawwarah alkali-feldspar granite, a component of the ring complex, as a metallogenically 


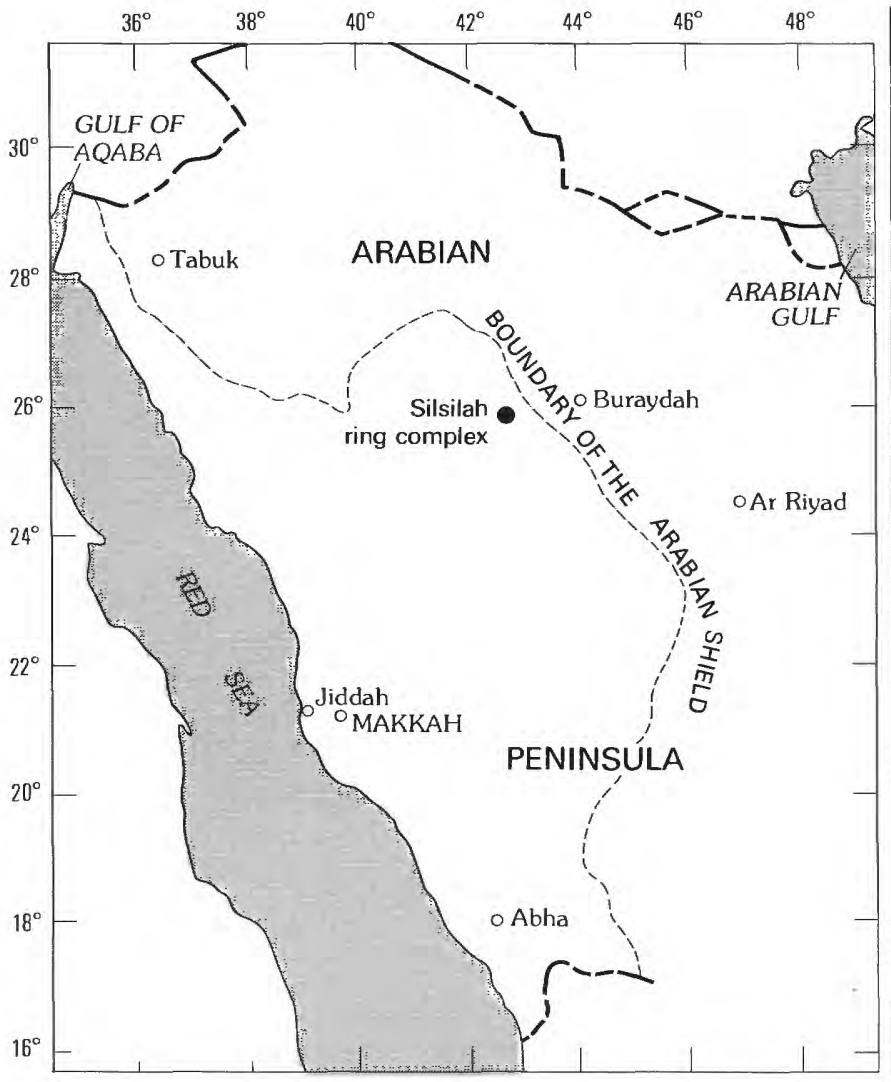

$0 \quad 100 \quad 200 \quad 300$ KILOMETERS

FIGURE 1. Index map of western Saudi Arabia showing the location of the Silsilah ring complex.

specialized granite, and he began a detailed study of the mineral potential associated with the rocks of the Silsilah ring complex. Two intensely mineralized cassiterite-bearing greisens, numerous weakly mineralized greisens, quartz veins with well developed greisen envelopes, and quartz-wolframite veins were identified in the southwest part of the ring complex and indicate that a major hydrothermal system has affected the rocks in this area. This report summarizes the geology and genesis of the Silsilah ring complex and the associated tin deposit (Saudi Arabian Mineral Occurrence Documentation System (MODS) locality number 03262).

The classification of igneous rocks used in this report follows the recommendations of the International Union of Geological Sciences subcommission on the nomenclature of plutonic rocks (Streckeisen, 1976). The alumina saturation indices as defined by Shand (1951) are employed to classify the chemistry of the plutonic rocks. Rocks with molar ratios of $\mathrm{Al} /(\mathrm{Na}+\mathrm{K})<1$ are peralkaline, with molar ratios of $\mathrm{Al} /(\mathrm{Na}+\mathrm{K})>1$ and $\mathrm{Al} /(\mathrm{Na}+\mathrm{K}+\mathrm{Ca})<1$ are metaluminous, and with molar ratios of $\mathrm{Al} /(\mathrm{Na}+\mathrm{K}+\mathrm{Ca})>1$ are peraluminous.

\section{ACKNOWLEDGMENTS}

This work was done in accordance with the work agreement between the U.S. Geological Survey (U.S.G.S.) and the Saudi Arabian Ministry of Petroleum and Mineral Resources. Early drafts were reviewed and improved by R. J. Kamilli, H. I. E. Hall, D. E. Lee, P. K. Sims, and J. E. Elliott. The author has benefitted from discussions with R. J. Kamilli, D. B. Stoeser, C. W. Smith, J. S. Stuckless and many others. Systems development work on the U.S.G.S. scanning electron microscope by J. E. Quick facilitated acquisition of composition data for feldspars and amphiboles. All modal analyses were performed by Ahmed Hamdan al Bazli. Lead isoptopic data were kindly provided by J. S. Stacey and L. B. Fischer.

\section{GENERAL GEOLOGY OF THE SILSILAH RING COMPLEX}

The Silsilah ring complex is an igneous suite, mostly composed of highly evolved rocks, that crops out in a ring-shaped feature and to a much lesser extent inside this feature. The circular ring complex is centered at lat. $26^{\circ} 07^{\prime} \mathrm{N}$. and long. $42^{\circ} 42^{\prime} \mathrm{E}$., about $150 \mathrm{~km}$ westsouthwest of Buraydah (figs. 1 and 2), near the northeastern limit of the exposed Arabian Shield. The composition and plutonic style of the rocks that compose the Silsilah ring complex are similar to those of other plutons exposed in the northeastern Arabian Shield emplaced between 580 and $570 \mathrm{Ma}$ ago (C. E. Hedge, oral commun., 1983). An U-Pb zircon age for the Fawwarah alkali-feldspar granite, the youngest component of the ring complex, is $587 \pm 8 \mathrm{Ma}$ (J. S. Stacey, written commun., 1984). Rocks of the ring complex intrude graywacke sandstone of the Murdama group; the sandstone crops out inside the ring complex and occurs in a large area outside the ring.

The rocks exposed in the ring complex form a prominent ring-shaped topographic feature, hereinafter referred to simply as the ring. The ring is $12 \mathrm{~km}$ in diameter and rises between 10 and $300 \mathrm{~m}$ above the surrounding pediment surface; the average relief along the ring is about $100 \mathrm{~m}$. Rock exposed in the ring has a cross-sectional area that ranges between $50 \mathrm{~m}$ in the northeast and about $2.5 \mathrm{~km}$ in the southeast and may represent magma whose emplacement was controlled by a set of closely spaced ring fractures.

The ring complex comprises three principal and several minor igneous rock types (plates 1 and 2). The Silsilah alkali granite (du Bray, 1983b) crops out prominently at Jabal as Silsilah and Jabal al Hadhir, located in the northwest and southeast quadrants, respectively, 


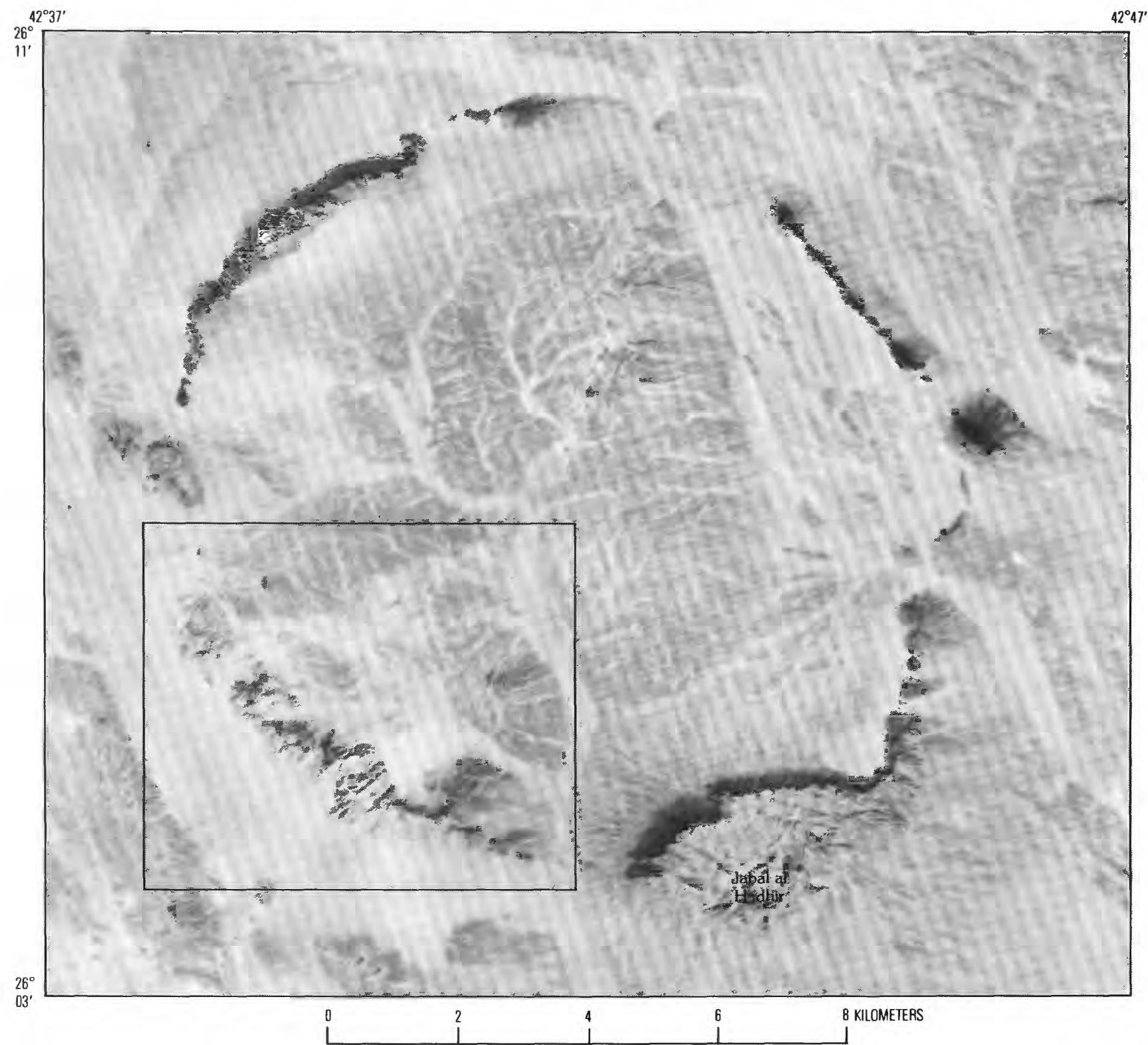

FIgURE 2. Photomosaic showing the Silsilah ring complex. The outer boundary indicates the area covered by plate 1 and the inner boundary shows the area covered by plate 2 .

of the ring, and forms a major proportion of the complex. The southwest quadrant is predominantly Fawwarah alkali-feldspar granite, and the Hadhir aplite (du Bray, 1983b) forms a carapace that overlies the alkali-feldspar granite. The alkali granite, alkali-feldspar granite, and aplite account for about 40,20 , and 10 percent of the ring complex, respectively. Two other rock types that crop out in the east and northeast quadrants together account for about 30 percent of the complex. One is composed of very fine grained alkaline rock types, including mugearite, benmoreite, trachyte, and tristanite, as defined by Irvine and Baragar (1971). These are alkaline analogs of dacite in the subalkaline volcanic rock classification system and hereinafter are collectively referred to as alkaline dacite for simplicity. The second type is fine-grained, porphyritic comendite (Noble, 1968). Both lithologies are characterized by textures that suggest that they were quenched. A distinctive comendite dike strikes northeast across much of the ring, and numerous siliceous dikes, whose relationship to the ring complex is uncertain, crop out just inside the southwest part of the ring. 
Rocks whose geneses are related to late-stage hydrothermal processes form a small but very important part of the complex. Very coarse grained quartz-potassium feldspar pegmatite occurs throughout the aplite but is most abundant in a zone between the Fawwarah alkalifeldspar granite and the Hadhir aplite. Quartz veins cut each of the plutons. Two intensely mineralized greisens, that locally contain high-grade accumulations of cassiterite, are located less than $1 \mathrm{~km}$ inside the southern part of the ring. Weakly mineralized greisens occur at several places inside the southwest part of the ring, and several more occur within the Fawwarah alkali-feldspar granite itself.

\section{HOST ROCK}

Murdama group rocks and their correlatives crop out over a very large area in the northern Arabian Shield and represent a major depositional basin. These rocks, known as the Maraghan lithic graywacke $(\mathrm{mlg})$ in this area (du Bray, 1983b), are intruded by, and therefore are older than, rocks of the Silsilah ring complex. These layered rocks surround the ring and are also exposed in a circular area of about $40 \mathrm{~km}^{2}$ within the ring.

The graywacke is massively bedded, immature sandstone and minor, interbedded siltstone which dips subvertically in most places and is compressed into open, though locally isoclinal, large-amplitude folds. Closely spaced, pervasive fracture cleavages also record deformation of the graywacke. Deformation occurred prior to emplacement of the ring complex rocks. The graywacke was regionally metamorphosed in lower greenschist facies conditions.

\section{INTRUSIVE ROCKS}

Petrographic features of the alkaline dacite, including vesiculation, tuffaceous textures, and very fine grain size suggest that some of the magma represented by these rocks vented and that the remainder solidified at a shallow depth. The alkaline dacite was intruded by all intrusive rocks with which it is in contact and, therefore, is the oldest part of the complex. The alkaline dacite weathers recessively and forms irregularly shaped outcrops with large length-to-width ratios; thus, it has features like those that characterize dikes.

A prominent porphyritic felsic dike trends northeast, intrudes metasedimentary rock along its $10-\mathrm{km}$ length within the ring, and forms a ridge $3-15 \mathrm{~m}$ high. The texture of the dike, including its tabular alkali feldspar phenocrysts, is similar to that of the Silsilah alkali granite and the comendite. The felsic dike may represent a fraction of alkali granite magma whose emplacement was controlled by a major country-rock fracture.

Fine-grained, porphyritic comendite occurs in the east and northeast parts of the complex. The comendite contains tabular alkali-feldspar phenocrysts similar to those of the Silsilah alkali granite. The texture of the comendite indicates that it represents magma that was quenched at a shallow level. Tuffaceous textures occur locally within the comendite and indicate that magma it represents vented in these places. Comendite outcrops, like those of the alkaline dacite, are dikelike in that they are irregularly shaped and have large lengthto-width ratios. Comendite intrudes the alkaline dacite and, therefore, is younger.

The Silsilah alkali granite, the predominant rock type of the ring complex, crops out prominently at Jabal as Silsilah and Jabal al Hadhir (plate 1). The greatest amount of dilation of the ring fracture system was achieved at Jabal al Hadhir where magma represented by the Silsilah alkali granite was emplaced. Contacts between the comendite and alkali granite are gradational. Intrusive relations at the southeastern edge of the ring complex locally indicate that the Silsilah alkali granite intrudes and, therefore, is younger than the alkaline dacite and comendite. The Silsilah alkali granite, unlike other units of the ring complex, is fractured and has undergone weak but pervasive deuteric alteration.

The compositional similarity between the alkali granite and the comendite, their close spatial association, and the similarity of their alkali-feldspar phenocrysts suggest that the comendite is a quenched equivalent of the alkali granite. The Silsilah alkali granite is finer grained and gradational to the finegrained, porphyritic comendite where the crosssectional area of alkali granite is least. Thus, comendite represents the initial emplacement of magma represented by these two lithologic units and owes its quenched appearance to rapid cooling against relatively cold country rock. The coarser grained alkali granite represents subsequent emplacement, and slower cooling, of this same magma into an environment warmed by previous intrusions. Lithologic types gradational between these two represent thermal conditions transitional between those that prevailed during solidification of the two end-member lithologies. The gradational nature of their mutual contacts and the occurrence of finer grained peralkaline rock in the parts of the ring complex with the smallest cross-sectional areas derive from these cooling rate relations.

The proto-Fawwarah alkali-feldspar granite, which is volumetrically minor and underlies the hills immediately north of the northernmost mass of the Hadhir aplite 
in the ring, is lithologically identical to the Fawwarah alkali-feldspar granite and was initially mapped with that unit. Subsequent examination of chemical data indicated that the trace-element chemistry of the protoFawwarah alkali-feldspar granite was statistically differentiable from that of the Fawwarah alkali-feldspar granite. Age relations between the proto-Fawwarah alkali-feldspar granite, the Hadhir aplite, and the Fawwarah alkali-feldspar granite were firmly established during a subsequent examination of contact relations. The proto-Fawwarah alkali-feldspar granite is intruded by the aplite which, in turn, is intruded by the Fawwarah alkali-feldspar granite.

The Hadhir aplite, which is generally covered by a dusky-brown weathering rind, is a volumetrically minor component of the ring complex that weathers recessively. It crops out as a nearly flat-lying sheet less than $50 \mathrm{~m}$ thick on top of the Fawwarah alkali-feldspar granite in the southwestern part of the ring complex (plate 2, fig. 3). The aplite also forms slabs located inside the southwestern limit of the ring complex where the Fawwarah alkali-feldspar granite forms small erosional windows in the overlying aplite. Other exposures, located about $4 \mathrm{~km}$ west of Jabal al Hadhir, where a sheet of aplite approximately $15 \mathrm{~m}$ thick underlies the Silsilah alkali granite (plates 1 and 2, fig. 4), indicate that the Hadhir aplite intrudes and, therefore, is younger than the Silsilah alkali granite.

Coarse-grained quartz and potassium feldspar and rare, oxidized fayalite form a nearly flat-lying pegmatitic zone that is present at most places between the Hadhir aplite and the underlying Fawwarah alkalifeldspar granite (fig. 5). The pegmatite has gradational contacts with both of these units. The zone pinches and swells along strike and is between 0.1 and $10 \mathrm{~m}$ thick.

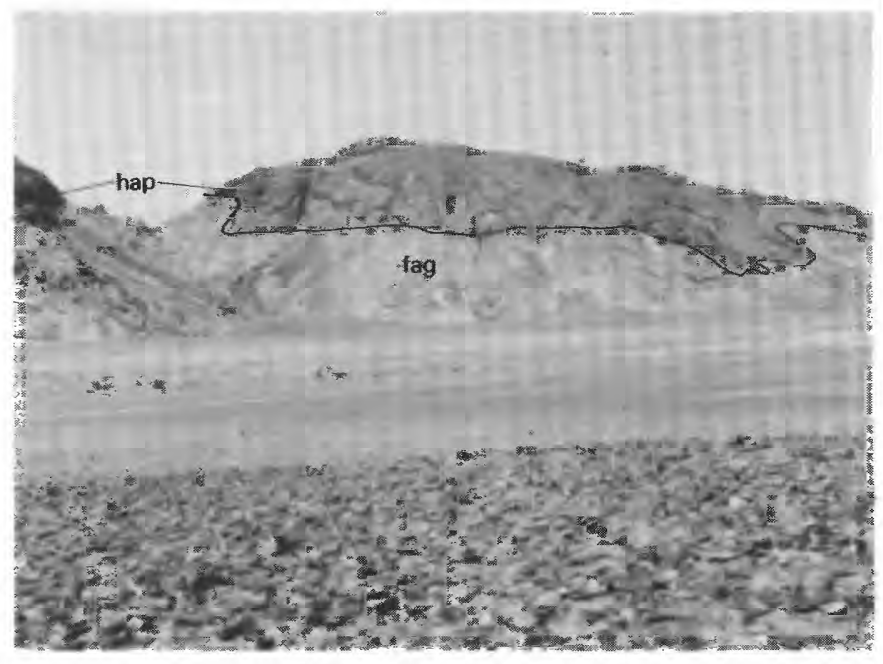

FIGURE 3. Photograph showing the sill-like Hadhir aplite (hap) overlying the Fawwarah alkali-feldspar granite (fag).

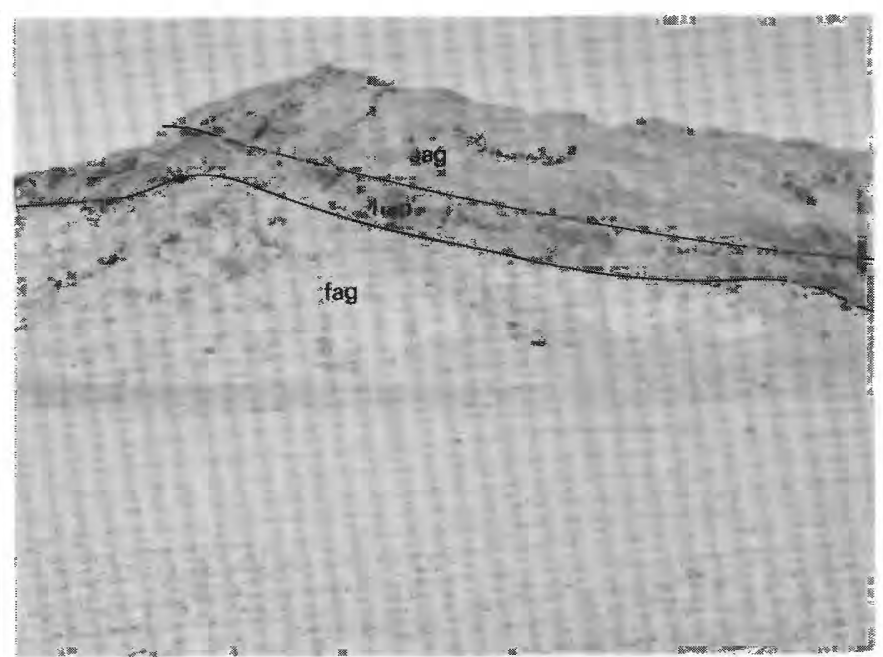

Figure 4. Photograph showing contact relations between the Silsilah alkali granite (sag), Hadhir aplite (hap), and Fawwarah alkali-feldspar granite (fag).

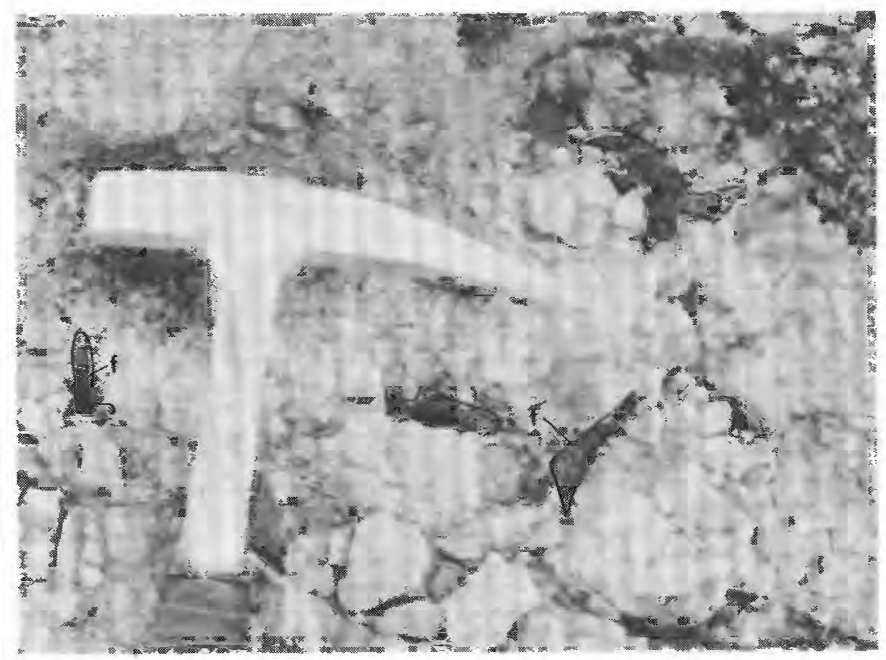

Figure 5. Photograph showing coarse-grained, quartz-potassium feldspar pegmatite that occurs in a sheet between the Hadhir aplite and the Fawwarah alkali-feldspar granite. Fayalite (f) forms bladed, interstitial crystals.

Pegmatitic rock is essentially absent in the upper part of the aplite. Within a few meters of the top of the pegmatitic zone, however, the aplite contains numerous pods of pegmatite $0.05-0.5 \mathrm{~m}$ in diameter. Much of the pegmatitic zone consists of a series of coalescing pods of pegmatite in a matrix of layered aplite. At the base of the pegmatitic zone, where alkali-feldspar granite is in contact with pegmatitic material, the alkali-feldspar granite has a slightly saccharoidal appearance. Trenching has demonstrated that pegmatite, again sandwiched between aplite and alkali-feldspar granite, underlies a prominent white quartz hill located $4.5 \mathrm{~km}$ southwest 
from the centerpoint of the complex. Pegmatitic potassium feldspar is clay altered and nonresistant, and most has been removed by erosion at the surface.

The Fawwarah alkali-feldspar granite crops out prominently in the southwestern quadrant of the ring beneath the Hadhir aplite (plates 1 and 2). It also underlies two small, isolated hills located 3 and $4 \mathrm{~km}$, respectively, inside the southwest margin of the ring where it clearly intrudes the metasedimentary rock inside the ring; it is demonstrably the youngest intrusive component of the ring complex. Quartz-potassium feldspar pegmatite pods, $5-50 \mathrm{~cm}$ in diameter, are found throughout the Fawwarah alkali-feldspar granite.

Fine-grained, siliceous dikes form low, arcuate ridges inside the southwest part of the ring. Very little is known about these dikes because they weather recessively and are very fine grained. Crosscutting relations between these reddish-brown dikes and other components of the complex were not observed making the relative age of these dikes uncertain. The arcuate character of these dikes suggests that they were emplaced in ring fractures that were forming as magma was being emplaced in a central chamber.

\section{QUARTZ VEINS AND JOINTS}

Rocks of the Silsilah ring complex, particularly the Fawwarah alkali-feldspar granite and the Silsilah alkali granite, are cut by well-developed joint sets which seem to have localized most of the quartz veins that cut these units. The joints have highly variable trends from one part of the ring to another. Joints and quartz veins trend N. $70^{\circ} \mathrm{W}$. in the western part of the Fawwarah alkali-feldspar granite and southwest of the ring's center, N. $40^{\circ} \mathrm{E}$. in the eastern part of the alkalifeldspar granite and in the Silsilah alkali granite east of Jabal al Hadhir, and N. $45^{\circ} \mathrm{W}$. at Jabal as Silsilah (plate 2). The rocks at Jabal al Hadhir are cut by joints that trend N. $70^{\circ} \mathrm{W}$. and N. $40^{\circ} \mathrm{E}$. (fig. 2, plates 1 and 2 ). The relation of these trends to regional strain patterns is unknown, although the joints that trend N. $70^{\circ}$ W. are nearly parallel to the major, transcurrent Najd faults that strike west-northwest across much of the Arabian Shield.

The Maraghan lithic graywacke, Hadhir aplite, and Silsilah alkali granite generally lack quartz veins. One quartz vein per $200 \mathrm{~m}$ of outcrop in these rocks is common. The Fawwarah alkali-feldspar granite is cut by about one quartz vein per $100 \mathrm{~m}$ of outcrop but, locally, vein densities may be as much as five veins per $10 \mathrm{~m}$. Quartz veins that penetrate the greisens are rare.

Most of the veins in the alkali granite are less than $1 \mathrm{~cm}$ wide, are randomly oriented, and do not appear to be mineralized. An exception is a set of quartz veins that trends N. $30^{\circ} \mathrm{W}$. in the alkali granite along a $1-\mathrm{km}-$ long segment of the ring at the south end of Jabal as Silsilah. The veins, $5-10$ per $100 \mathrm{~m}$ of traverse, range in width from 2 to $50 \mathrm{~cm}$. These veins are continuous in width along strike and show no indication of being mineralized. A second exception is a set of N. $40^{\circ}$ E.trending quartz veins that cut the Silsilah alkali granite at the extreme southern end of the ring complex. These veins originate at the top of the Fawwarah alkalifeldspar granite where it underlies both the Hadhir aplite and the Silsilah alkali granite (plate 2). The veins of this set are distinctly mineralized and are wider and more numerous than those of the N. $30^{\circ} \mathrm{W}$.-trending set. Many of the N. $40^{\circ}$ E.-trending veins, which have greisen envelopes that contain distinctive quantities of Fe-Li mica and fluorite, contain euhedral blades of wolframite. The easternmost veins of this set appear to contain the greatest quantity of wolframite.

Quartz veins in the Fawwarah alkali-feldspar granite trend N. $70^{\circ} \mathrm{W}$. and N. $40^{\circ}$ E., respectively, and are $2-4 \mathrm{~cm}$ wide, and many are as much as 0.5 to $1.0 \mathrm{~km}$ long. They are enclosed in weakly oxidized envelopes and many contain metallic or iron oxide minerals. Small, bladed crystals of wolframite were identified in some veins.

One large quartz vein having a well-developed greisen envelope cuts across the ring near the north end of the alkali-feldspar granite (plate 2). The vein is $1 \mathrm{~m}$ wide along the middle part of its length, where it contains concentrations of coarse-grained, bladed wolframite (fig. 6). It splays to a set of $1-\mathrm{cm}$-wide veins to the east and west. A swarm of many small quartz veins, some of which are wolframite bearing, was identified in the area immediately north and west of this large vein.

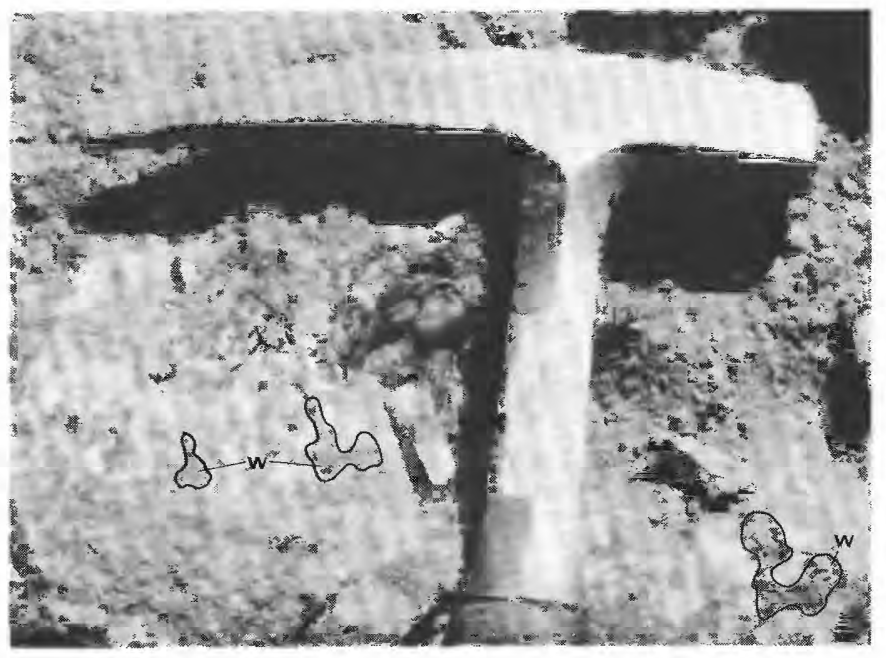

Figure 6. Photograph showing wolframite $(w)$ in the large quartz vein that transects the north end of the Fawwarah alkali-feldspar granite. 
The northern two of three small patches of Fawwarah alkali-feldspar granite that crop out within the ring (plate 2) are cut by a large number of N. $70^{\circ} \mathrm{W}$.-trending quartz veins that have well-developed greisen envelopes. These veins are typically $2-4 \mathrm{~cm}$ wide, are persistent along strike, and have a density of two or three veins per 10 meters of outcrop. Wolframite was identified in some of these veins. In several places, where veins intersect prominent joints, small, dense accumulations of cassiterite were encountered.

\section{GREISENS}

Two types of greisenized, hydrothermally altered rock occur within the Silsilah ring complex. The two types represent complete and incomplete greisenization of the Fawwarah alkali-feldspar granite. Relationships seen in outcrops, shallow trenches, and diamond-drill core demonstrate that intensely tin-mineralized, complete greisen occurs immediately below the pegmatitic zone, at the top of the Fawwarah alkali-feldspar granite. Complete greisen forms a zone 0.1-2 $\mathrm{m}$ thick that grades downward into the underlying incomplete greisen. Incomplete greisen grades downward into progressively less altered Fawwarah alkali-feldspar granite; fresh, unaltered rock occurs within about $40 \mathrm{~m}$ of the surface. Recognition that the occurrence of mineralized greisen is restricted to the top of the alkali-feldspar granite is important in identifying other areas within the Silsilah ring complex that might be favorable for tin exploration.

Greisenized rock is found throughout the southwest part of the Silsilah ring complex. Complete greisen underlies two small, irregularly shaped areas located less than $1 \mathrm{~km}$ inside the southwestern part of the ring (plate 2, fig. 7) and numerous small areas west of the largest of the three areas underlain by Fawwarah alkalifeldspar granite within the ring (plate 1). Incomplete greisen is more abundant than complete greisen and occurs in numerous areas throughout the southwest part of the complex.

Complete greisen is very light gray to pinkish gray and is characterized by a mineral assemblage that includes quartz, topaz, cassiterite, and trace amounts of opaque oxides and Fe-Li mica. Disseminated grains of cassiterite constitute from less than 1 to about 10 percent of complete greisen. Cassiterite also occurs in spectacular elliptical, pod-shaped accumulations that are 0.05-5 $\mathrm{m}$ in diameter and are composed of as much as 90 percent, but more commonly 50 percent, cassiterite; quartz and topaz form the matrix for these accumulations. Contacts between almost barren quartz-topaz rock and the pod-shaped accumulations of cassiterite are extremely sharp (fig. 8).

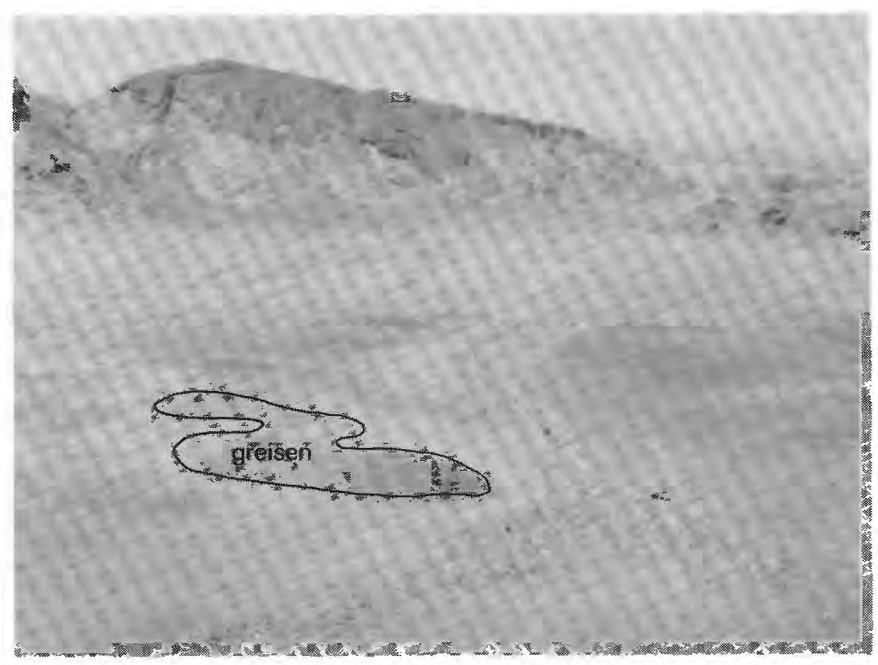

FIGURE 7. Photograph showing an aerial view of the intensely mineralized southern greisen.

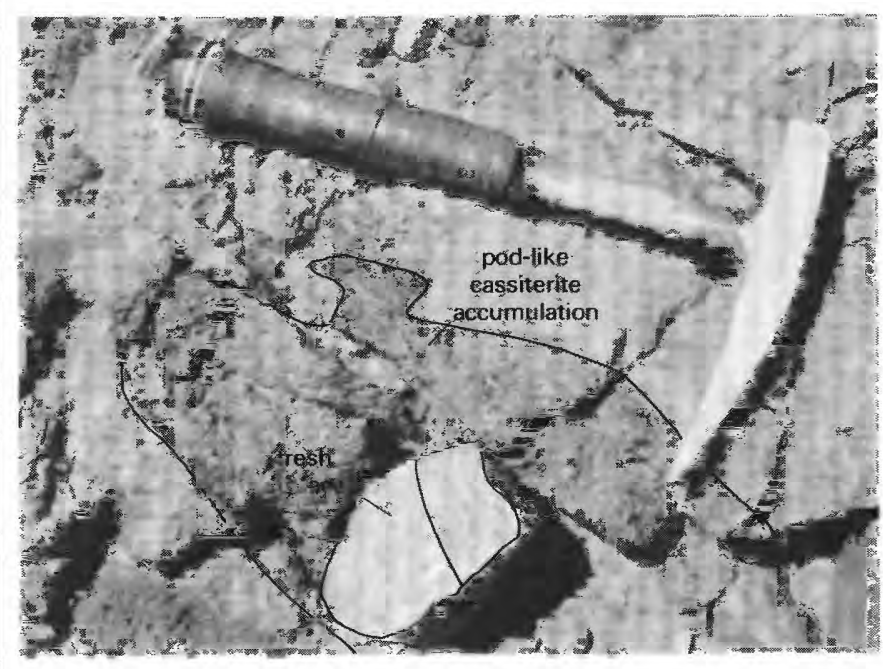

Figure 8. Photograph showing the contact between quartzcassiterite-topaz greisen and a podlike accumulation of cassiterite on weathered and fresh surfaces. The fresh fragment shows that the contact between very high-grade accumulations of cassiterite and host quartz-topaz-cassiterite greisen is very sharp.

Incomplete greisen is greenish gray and is characterized by a mineral assemblage that includes quartz, Fe$\mathrm{Li}$ mica, topaz, and trace amounts of fluorite, albite, and cassiterite. The presence of incomplete greisen may, because of the spatial relationship that exists between the two greisen types, indicate the nearby, though unexposed, presence of intensely tin-mineralized complete greisen.

Some occurrences of incomplete greisen lack evidence of associated complete greisen. Incomplete greisen that occurs in this mode forms areas that are approximately elliptical in shape and are between 10 and $200 \mathrm{~m}$ in 
diameter. Several isolated lenses of incomplete greisen are enclosed by Fawwarah alkali-feldspar granite in the southeasternmost part of that pluton. Isolated areas also occur near the three small masses of alkali-feldspar granite located within the ring (plate 2). Greisen near but not in contact with the central of these three masses is surrounded by lithic graywacke. Additional incomplete greisen was identified on the northwestern slope of the prominent white hill underlain by pegmatite. The rock that forms these isolated masses of incomplete greisen is not intensely mineralized, although cassiterite was identified in some hand samples. In several cases, these greisens appear to be structurally controlled. Joints may have acted as conduits for hydrothermal fluids that caused the greisenization. In other cases, the greisens are spatially unrelated to fractures and joints and the localizing factors are unknown. The texture and composition of the incomplete greisen that forms these isolated occurrences are the same as those characteristic of greisen envelopes associated with some quartz veins.

\section{RING FRACTURE}

The large size and circular shape of the Silsilah ring complex suggest that the rocks preserved therein represent a fraction of magma tapped from a large, subjacent magma chamber. Structural considerations, quench textures in some of the ring complex components, and pegmatitic pockets in others indicate that these intrusive rocks crystallized at a shallow depth. Extrusive products that may have been part of the ring complex have been removed by erosion; an exception is the parts of the alkaline dacite and comendite that appear to have vented in the east and northeast parts of the complex. The Silsilah ring complex, the cauldron complexes described by Smith and Bailey (1968), and the ring complexes of Nigeria (Bowden and Turner, 1974) are similar in that they are composed of moderately to highly evolved granite or rhyolite, form circular or ring-shaped structures with central, core plutons, and many have associated mineral deposits.

Contacts between the graywacke and intrusive rocks are obscured by alluvial deposits. As a consequence, direct evidence regarding the emplacement mechanics of the ring complex is lacking. Rocks of the Murdama group exposed inside and just outside the ring are deformed to the same extent as metasedimentary rocks exposed some distance away. Stoping was not the primary mechanism of magma emplacement because blocks of the host metasedimentary rocks within the intrusive units are rare and small in size. Small-scale stoping features were observed, however, in the lithic graywacke that hosts the two intensely mineralized greisens. These observations suggest that, following upward propagation of the ring fracture system, emplacement of magma was achieved without further wall-rock deformation.

Evidence favoring piston like subsidence of a central core, as demonstrated for many large calderas (Smith and Bailey, 1968), was not observed. The concentric fault patterns and moat fills that are associated with caldera core subsidence are not apparent, although they may be covered by the alluvial deposits that drape the inner and outer borders of the ring structure. However, the presence and structural condition of the Maraghan lithic graywacke inside the ring argues against a major episode of cauldron subsidence. If they had experienced significant piston like subsidence, these rocks would be significantly more disrupted and dismembered. There is little evidence of dike injection that would have occurred in a structurally dismembered, foundered block located above an active magma chamber.

Several lines of evidence indicate that igneous rock, presumably the central pluton from which the currently exposed rocks of the ring complex evolved, is present at a shallow depth below the graywacke sandstone exposed inside the ring structure. Reconnaissance audiomagnetotelluric profiles across the Silsilah ring complex indicate that the thickness of the Murdama group rocks at the center of the ring complex does not exceed several hundred meters (Flanigan and Zablocki, 1983). The presence of the two cupolalike bodies of Fawwarah alkalifeldspar granite inside the ring, of aplite dikes that penetrate the graywacke sandstone near these granitic massifs, and of hydrothermally altered rock throughout the southwestern quadrant of the ring complex also suggest that igneous rock is present at a shallow depth.

\section{RADIOACTIVITY}

A total-count scintillometer having a cylindrical $(38.1 \times 38.1-\mathrm{mm})$ sodium iodide detection crystal was used to measure radioactivity at most sample sites in the Silsilah ring complex. The instrument was set on a planar outcrop at each site and allowed to equilibrate before a measurement was made. Results of the scintillometer survey are given below in counts per second (cps); data for granites of the eastern Arabian Shield (du Bray and others, 1982) are given for comparison:

\begin{tabular}{lccc}
\hline Site & $\begin{array}{c}\text { Number of } \\
\text { measurements }\end{array}$ & $\begin{array}{c}\text { Mean } \\
\text { (cps) }\end{array}$ & $\begin{array}{c}\text { Standard } \\
\text { deviation (cps) }\end{array}$ \\
\hline East Shield & 600 & 50 & 31 \\
$\begin{array}{l}\text { Silsilah alkali } \\
\text { granite }\end{array}$ & 32 & 47 & 11 \\
Hadhir aplite & 10 & 73 & 18 \\
Fawwarah alkali- & 54 & 103 & 25 \\
$\quad$ feldspar granite & & & \\
\hline
\end{tabular}

The radioactive decay of potassium is not responsible for the maximum radioactivity values associated 
with the alkali-feldspar granite because potassium is more abundant in the less-radioactive alkali granite (table 1). The measured increase of radioactivity associated with the oldest component of the ring complex to that associated with the youngest is consistent with the radioactive decay of uranium and thorium, which are systematically more abundant in the younger components (table 2).

The radioactivity of the Silsilah alkali granite is not anomalous nor is the radioactivity of the Hadhir aplite more than one standard deviation greater than the average value for the granitoid rocks of the eastern
Arabian Shield. The average value for the Fawwarah alkali-feldspar granite is twice that value and individual measurements are as much as three times that value. Measurements made at individual sample sites are plotted according to intensity (fig. 9). The plot indicates that the radioactivity of the younger phase of the alkalifeldspar granite is distinctly higher than the radioactivity of the proto-alkali-feldspar granite. Uranium and thorium contents are deduced to be higher in the younger phase than in the older phase. Otherwise, the radioactivity of the alkali-feldspar granite is not discernibly zoned.

TABLE 1.-Major-element analyses and CIPW normative compositions for intrusive rocks of the Silsilah ring complex

[Major oxides and normative minerals in weight percent. Leader indicates nil amount. Ferrous-ferric ratio adjusted for samples of alkaline dacite and comendite along guidelines suggested by Irvine and Baragar (1971), prior to norm calculation]

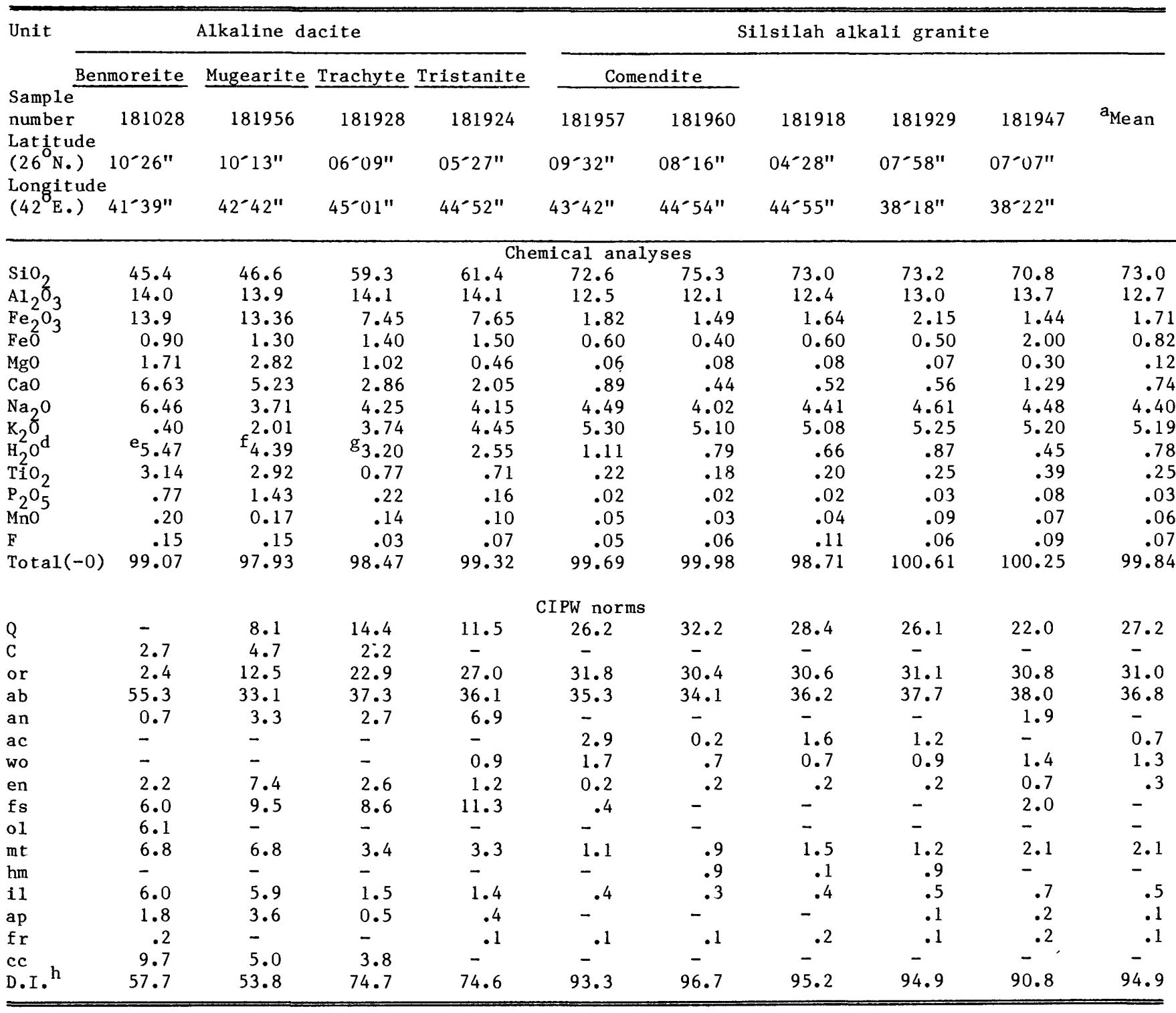


TABLE 1.-Major-element analyses and CIPW normative compositions for intrusive rocks of the Silsilah ring complex-Continued

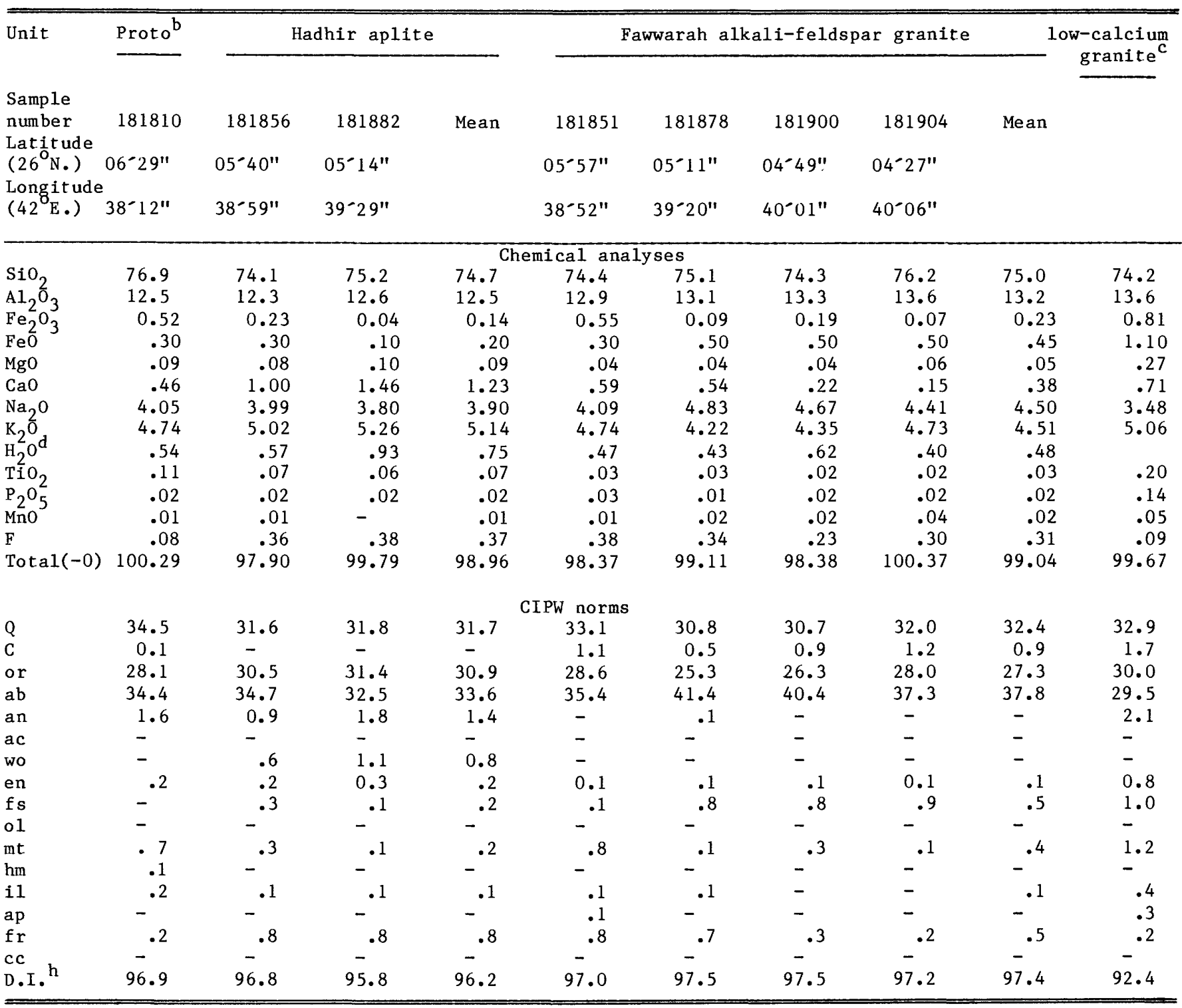

a Includes data for two samples of comendite.

b Proto-Fawwarah alkali-feldspar granite.

c Turekian and Wedepohl (1961).

d $\mathrm{H}_{2} \mathrm{O}$ equals loss on ignition minus $\mathrm{F}$.

e Includes 4.2 percent $\mathrm{CO}_{2}$.

$f$ Includes 2.1 percent $\mathrm{CO}_{2}$.

$g$ Includes 1.6 percent $\mathrm{CO}_{2}$.

h D.I. is sum of Q, or, and ab.

\section{PETROGRAPHY}

\section{MARAGHAN LITHIC GRAYWACKE}

The graỹwacke is principally composed of brownishgreen to olive-gray, fine-grained sandstone, but it also includes medium-grained sandstone and siltstone. The matrix is a silt-size intergrowth of turbid, fine-grained clay minerals and, where metamorphism was more intense, biotite is common and the sandstone has a spotted appearance. The spots are less than $1 \mathrm{~mm}$ in diameter and are composed of small porphyroblastic clots of biotite. The matrix has locally been replaced by carbonate and (or) ferruginous material. 
The clast population is simple. Volcanic lithic clasts (50 percent) outnumber monocrystalline quartz clasts (30 percent) which, in turn, are more abundant than subangular clasts of plagioclase ( 20 percent). Potassium feldspar clasts are extremely rare. The lithic fragment suite includes felsite, turbid grains of argillite, and distinctive, fine-grained volcanic clasts that contain small phenocrysts of plagioclase. Trace amounts of zircon, opaque oxides, and epidote are present. The graywacke was regionally metamorphosed under very low grade conditions; the metamorphic grade was not significantly enhanced by emplacement of the ring com. plex rocks.

The characteristics of the Maraghan lithic graywacke are typical of immature, rapidly deposited molasse deposits, as defined by Williams and others (1954). The graywacke is poorly sorted and massively bedded, although finely laminated strata were identified locally. Clasts are angular to subangular and elongate. Porosity is low and the rock is grain supported.

\section{ALKALINE DACITE}

The very fine grained, grayish-black to blackish-red alkaline dacite is hypidiomorphic granular and is composed of an inequigranular, intergranular to weakly trachytic intergrowth of plagioclase and magnetite (fig. 10). The rock is composed of 50-80 percent unzoned, subhedral plagioclase laths $0.2 \mathrm{~mm}$ long. Locally, plagioclase was stained pale orange by release of iron oxides resulting from conversion of magnetite to hematite during weathering. Euhedral plagioclase phenocrysts, $1.0 \mathrm{~mm}$ long, compose 10 to 20 percent of the rock in some areas and give the rock a porphyritic texture. Anhedral to subhedral grains of magnetite $0.05 \mathrm{~mm}$ in diameter compose 20 to 30 percent of the rock. Some samples contain aggregates of chlorite grains, transected by opaque-oxide-coated fractures, that appear to have pseudomorphously replaced subhedral olivine grains that were $1 \mathrm{~mm}$ in diameter. A trace amount of interstitial chlorite, in ragged flakes $0.1 \mathrm{~mm}$ long, were identified in some samples. Apatite, in subhedral grains $0.01 \mathrm{~mm}$ long, is the only accessory mineral and forms 1 percent of some samples. Interstitial, secondary calcite composes 5 percent of many samples. Vesicles 1 to $3 \mathrm{~mm}$ in diameter were observed in some samples. The vesicles are filled by botryoidal growths principally composed of calcite and ferruginous material but also include quartz and chlorite.

TABLE 2.-Trace- and rare-earth-element analyses for intrusive rocks of the Silsilah ring complex

[All values in parts per million. S.d. is standard deviation. Leader indicates no variance. $\mathrm{N}$ indicates not detected at the indicated value. $\mathrm{L}$ indicates less than the indicated value]

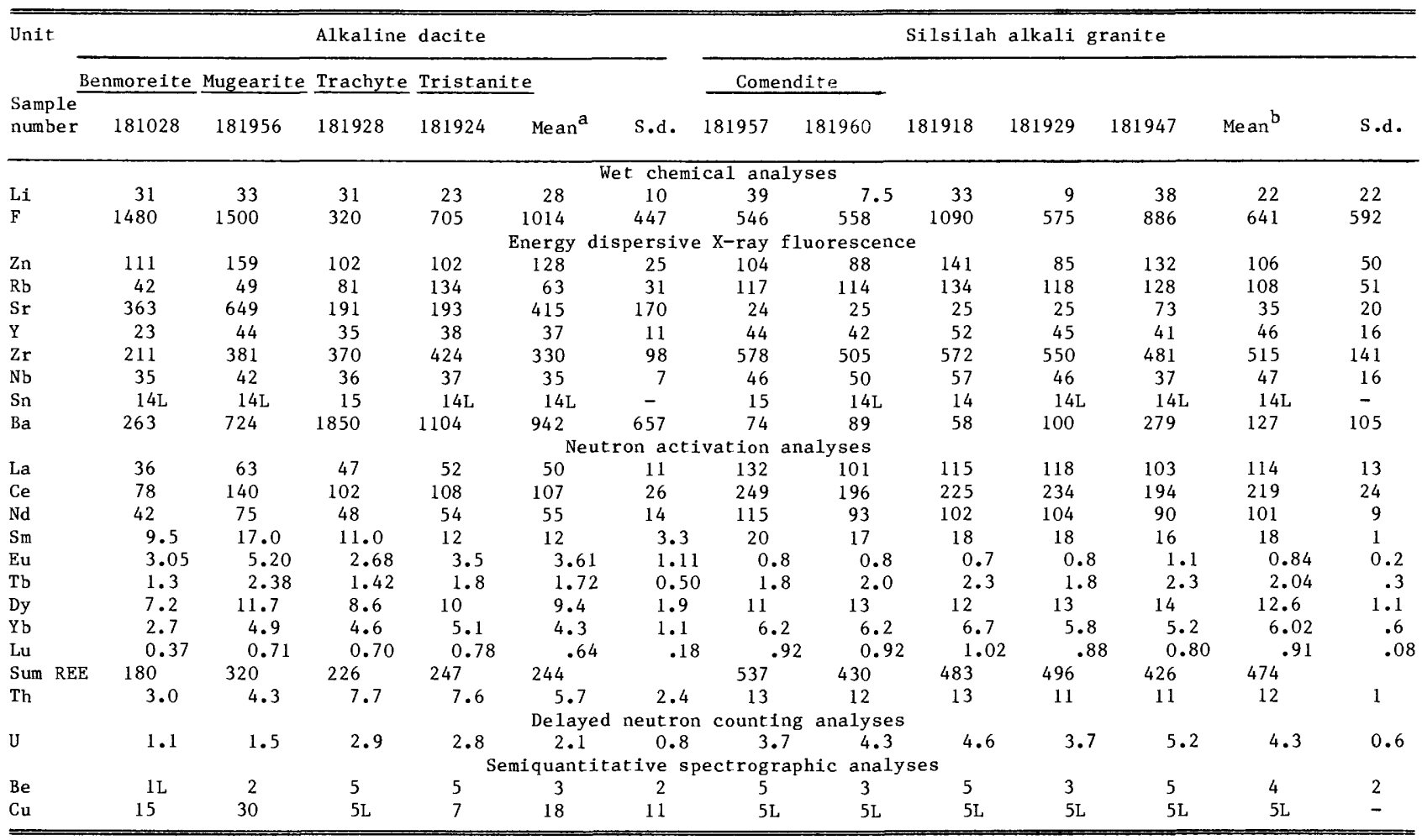


TABLE 2.-Trace and rare-earth element analyses for intrusive rocks of the Silsilah ring complex-Continued

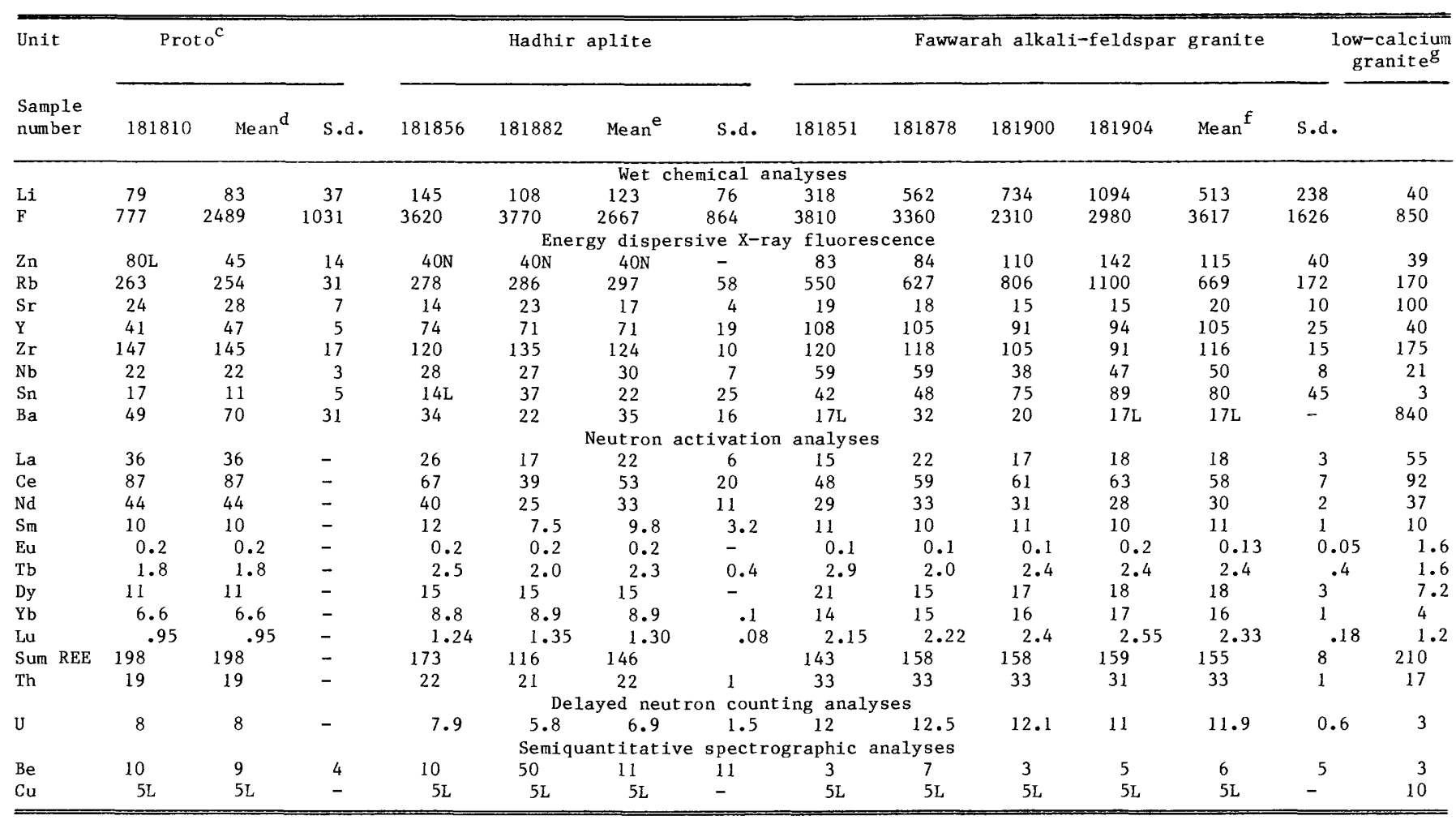

a Elemental means based on data for 9 samples, except rare-earth element, sum REE, U, and Th means, which are based on dat a shown

b Elemental means based on data for 43 samples, including comendites, except for rare-earth element, sum REE, U, and Th means which are based on data shown

c Proto-Fawwarah alkali-feldspar granite

d Elemental means based on 9 samples, except rare-earth element, sum REE, U, and Th means, which are based on data shown

e Elemental means based on 15 samples, except rare-earth element, sum REE, U, and Th means, which are based on data shown

f Elemental means based on 43 samples, except rare-earth element, sum REE, U, and Th means, which are based on data shown

$g$ Turekian and Wedepohl (1961)

\section{COMENDITE}

This fine-grained, pale reddish-brown rock is allotriomorphic to hypidiomorphic granular and is distinctly porphyritic (fig. 11). Quartz forms rounded to bipyramidal phenocrysts $2-4 \mathrm{~mm}$ in diameter that are anhedral to subhedral and compose about 5 percent of the rock. Antiperthitic anorthoclase forms subhedral to euhedral Carlsbad-twinned laths 3-4 mm long, weakly altered to sericite, and composes about 60 percent of the rock. These phenocrysts occur, in some samples, in irregularly shaped clusters $0.5-1 \mathrm{~cm}$ in diameter. Anhedral, interstitial albite forms only 10 percent of the rock, although in some samples all feldspar has been albitized by late-stage fluids. Ragged, interstitial, opaque oxide grains are $0.2-4 \mathrm{~mm}$ in diameter and form about 1 percent of the rock. Spindle-shaped laths of arfvedsonite 0.2-0.5 mm long compose another 2-3 percent of the rock. The matrix is composed of irregularly shaped, interstitial patches of quartz and feldspar in micrographic intergrowth, of spherulitic overgrowths of anorthoclase on quartz and anorthoclase phenocrysts, and of fine-grained aggregates of quartz and alkali feldspar. Miarolitic cavities 1-3 $\mathrm{mm}$ in diameter that are filled with albite occur in some samples.

The petrography of the prominent northeast-trending dike is very similar to that of the comendite. In particular, anorthoclase phenocrysts and the micrographic and spherulitic groundmass of the dike are similar to those observed in the comendite. However, the groundmass of the dike is more distinctly micrographic than that of the comendite.

\section{SILSILAH ALKALI GRANITE}

The medium-grained alkali granite is grayish-red, hypidiomorphic granular, (fig. 12) and locally characterized by a micrographic groundmass. The groundmass is typically a fine-grained, allotriomorphic 


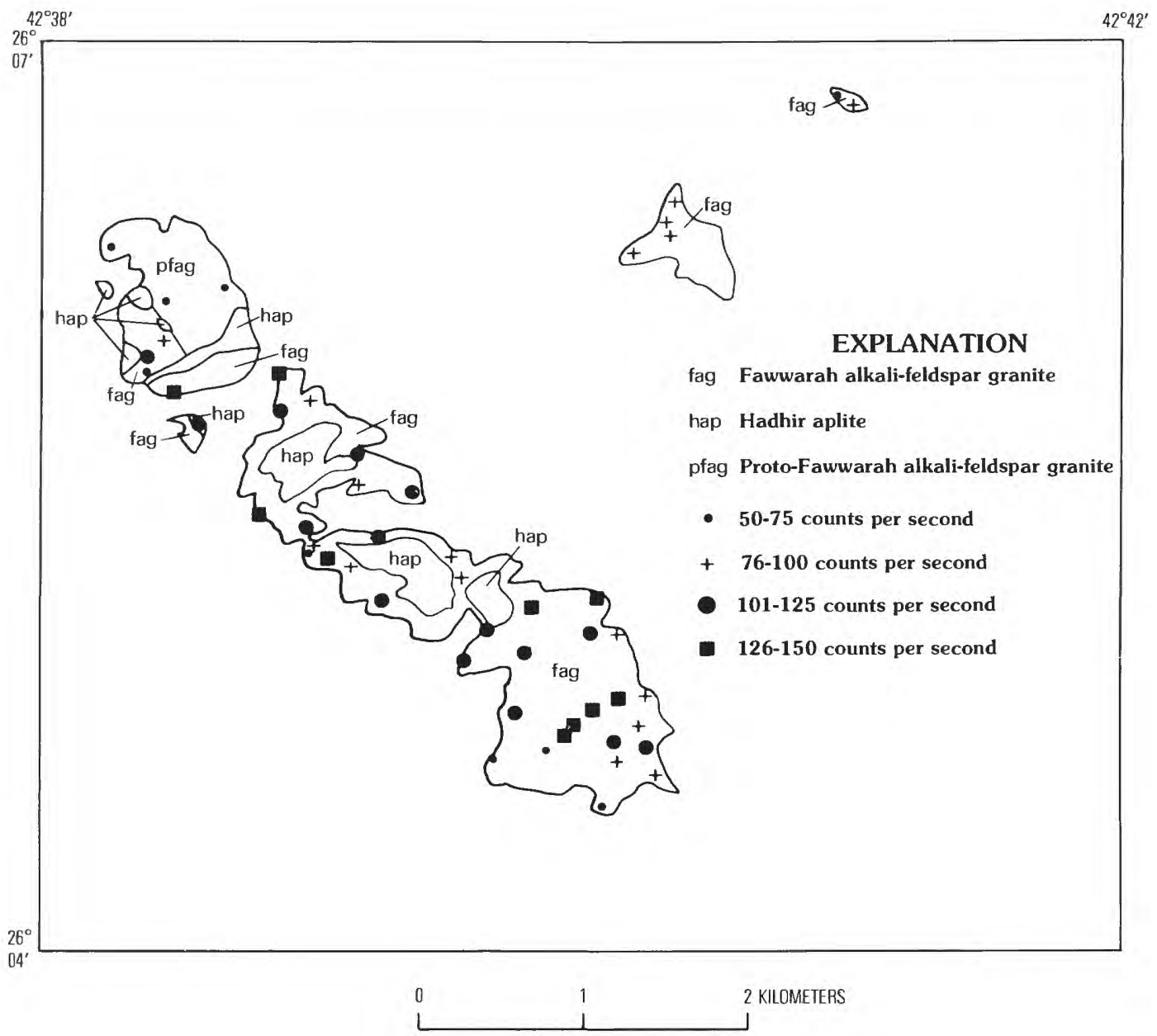

FIGURE 9. Map showing total-count radioactivity at sample sites in the Fawwarah alkali-feldspar granite.
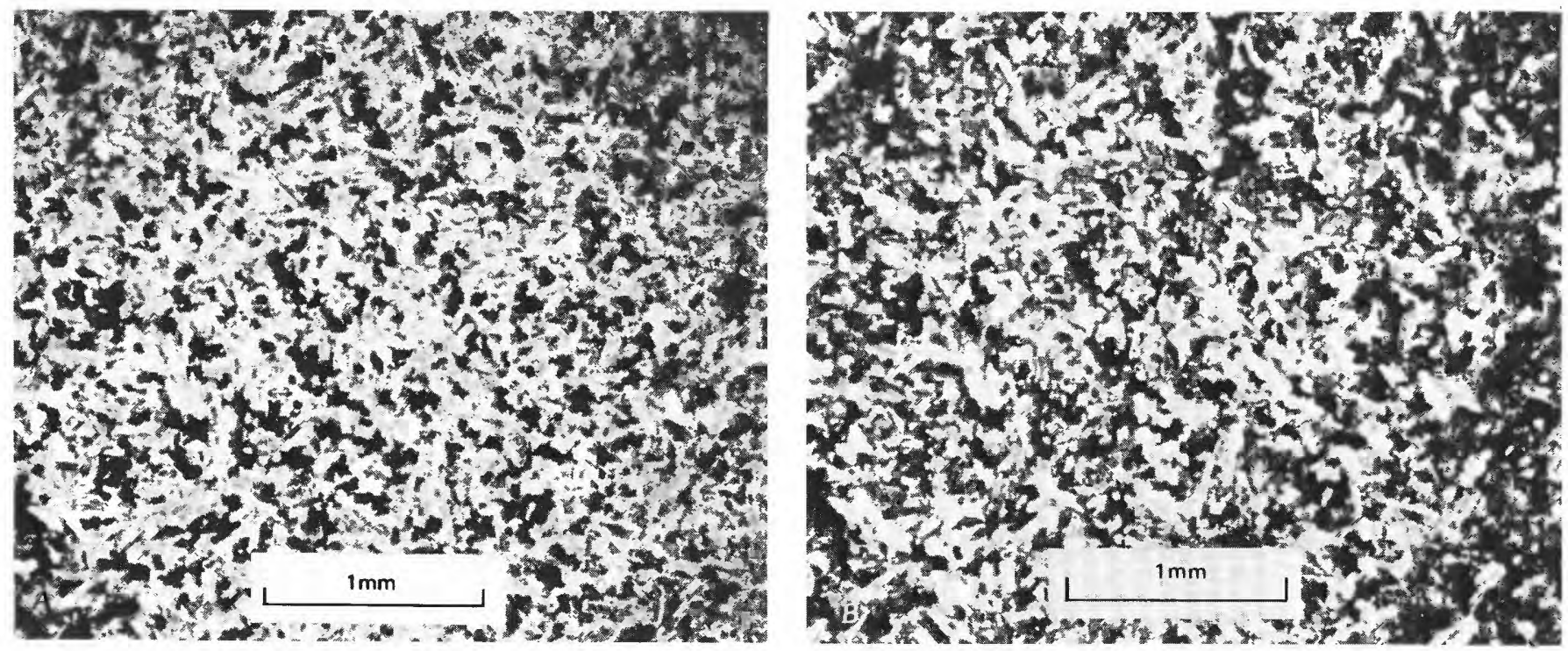

FiguRE 10. Photomicrographs of the alkaline dacite showing the intergranular texture of plagioclase and opaque oxides that characterizes this rock. $A$, Uncrossed nicols; $B$, Crossed nicols. 

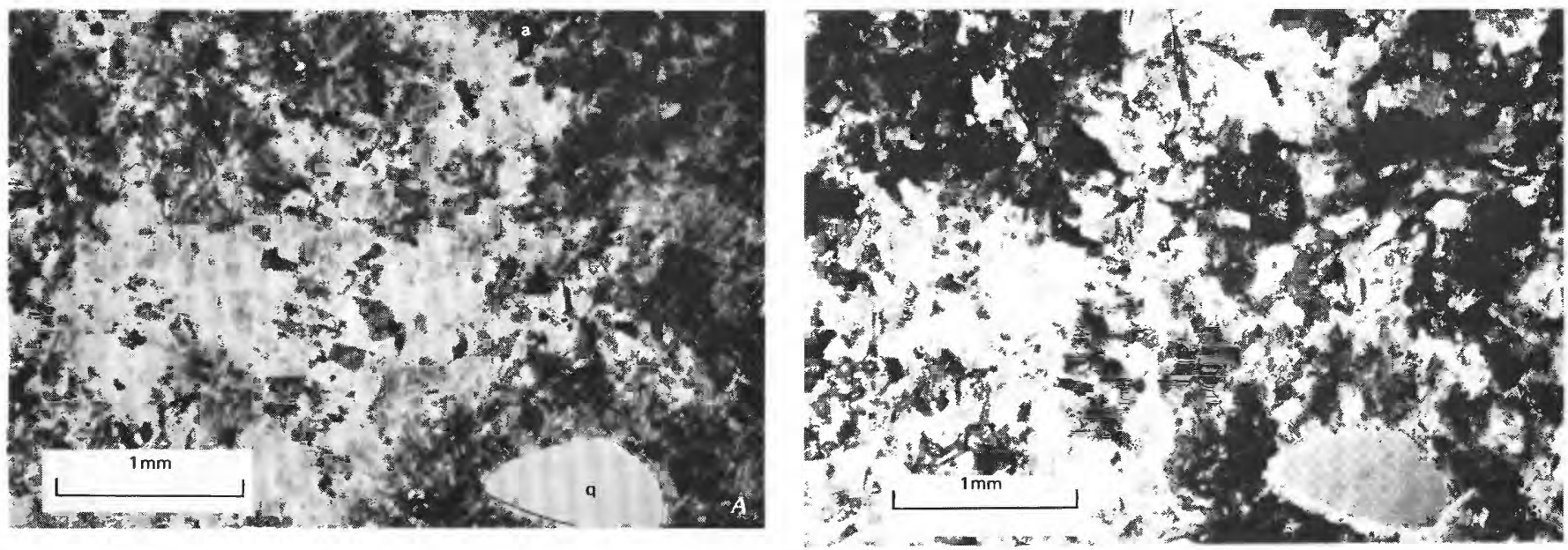

FIGURE 11. Photomicrographs of the comendite showing the micrographic, porphyritic, and spherulitic textures that characterize this rock. Quartz (q), arfvedsonite (a), and spherulitic anorthoclase (s) are indicated. $A$, Uncrossed nicols; $B$, Crossed nicols.

granular intergrowth of quartz, antiperthitic anorthoclase, and a small amount of albite. The felsic constituents are albite, quartz, and alkali feldspar; average contents of these minerals are 10, 21 , and 63 percent, respectively, as determined by modal analyses of 14 stained slabs (fig. 13); the color index is 6 . High albite contents and a distinctly pinkish coloration in some samples of this pluton (fig. 13) are a result of localized, late-stage albitization. The Silsilah alkali granite is weakly recrystallized and deuterically altered for several hundred meters from its contact with the Hadhir aplite. The rock exposed at Jabal as Silsilah and Jabal al Hadhir is unaltered.

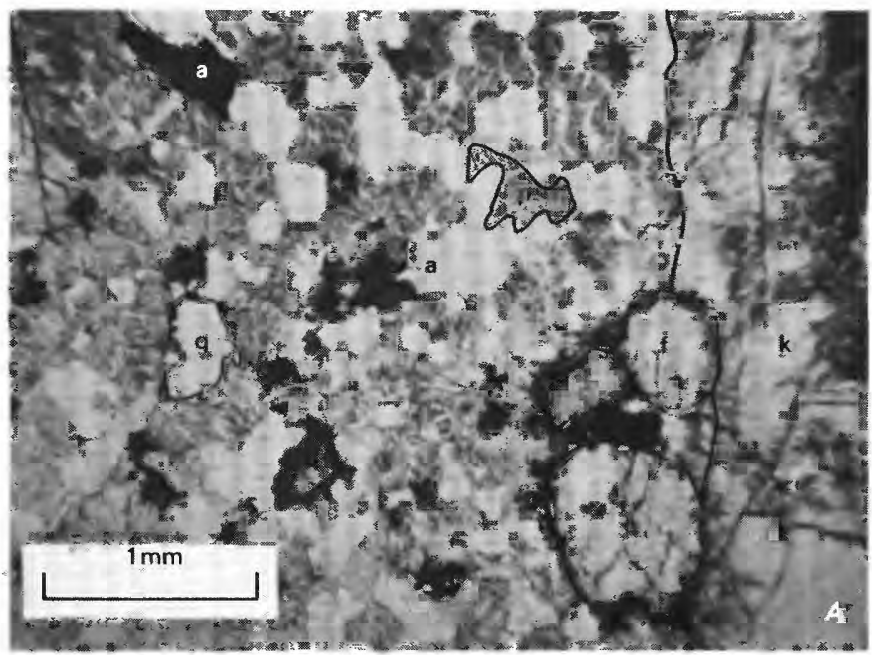

Phenocrysts of quartz and anorthoclase give the alkali granite a distinctly porphyritic character. Anhedral, rounded quartz phenocrysts are 1-2.5 mm in diameter. Rather common fluid inclusions in quartz are 30-50 microns in diameter. The inclusions are liquid dominated and contain small vapor bubbles. Blocky laths of antiperthitic anorthoclase form subhedral to euhedral, Carlsbad- and (or) gridiron-twinned, phenocrysts 3-4 mm long. The amount of perthitic exsolution is variable among samples. Albite forms subhedral phenocrysts $1 \mathrm{~cm}$ long in a few samples but is principally found in the groundmass.

Calcic-sodic amphiboles such as ferroedenite and

FIGURe 12. Photomicrographs of the Silsilah alkali granite showing the hypidiomorphic granular and porphyritic textures that typify the unit. Grains of arfvedsonite (a), fayalite (f), perthite (p), quartz (q), and a phenocryst of anorthoclase (k) are indicated. $A$, Uncrossed nicols; $B$, Crossed nicols. 


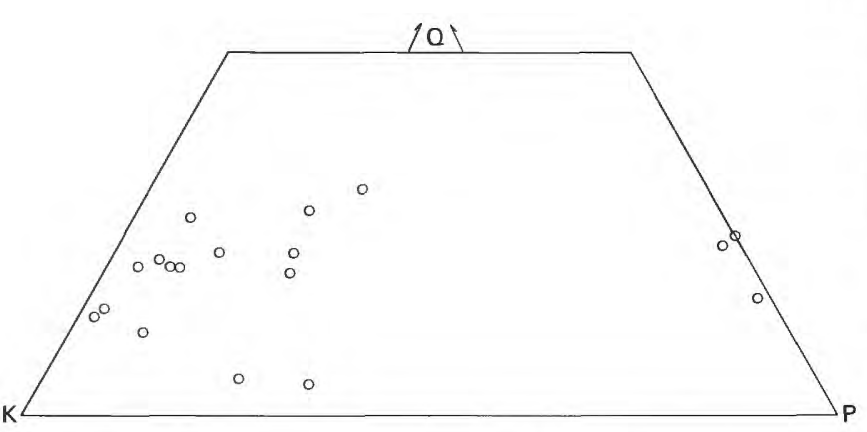

Figure 13. Ternary quartz-potassium feldspar-plagioclase (QKP) diagram showing the modal composition of the Silsilah alkali granite; the sum of Q, K, and P is normalized to 100 percent. Each plotted point represents a modal analysis (between 300 and 700 points counted on a stained slab measuring at least $50 \mathrm{~cm}^{2}$ ) for a single sample. Albite is counted as plagioclase so that the ratio of albite to potassium feldspar is discernible. Figure can be converted to a Streckeisen (1976) diagram by replotting points on the Q-K sideline of the ternary diagram, at the $\mathbf{Q}$ content indicated for each plotted point.

katophorite, minor arfvedsonite, and the sodic pyroxene aegirine-augite are the principal mafic silicates in the alkali granite. Ferroedenite forms anhedral grains 2-3 mm long. Aegirine-augite forms rounded, subequant emerald-green grains $1 \mathrm{~mm}$ in diameter. Katophorite forms blackish-green, anhedral grains $0.4 \mathrm{~mm}$ in diameter. A trace amount of arfvedsonite forms indigo-blue grains $0.2 \mathrm{~mm}$ in diameter. Secondary redbrown biotite, identified in several samples, forms anhedral to subhedral grains $2 \mathrm{~mm}$ long. Fayalite was identified in one sample as rounded grains, showing the characteristic parting observed in olivine. The grains are $0.5-1 \mathrm{~mm}$ in diameter and have been replaced by a fine-grained intergrowth of serpentine and opaque oxides. Fayalite is described in only one other granitoid rock of the Arabian Shield (D. B. Stoeser, oral commun., 1983) but is a common constituent in the peralkaline rocks that compose the young ring complex granites of Nigeria (Bowden and Turner, 1974). Most mafic silicate grains have been affected by late-stage magmatic fluids; they have been converted, wholly or in part, to aggregates of hematite and other opaque oxides. Accessory minerals are opaque oxides, zircon, and a trace amount of allanite. Secondary calcite fills fractures.

\section{HADHIR APLITE}

The Hadhir aplite is a very light gray rock that is inequigranular, fine grained, and allotriomorphic granular (fig. 14). The felsic constituents are albite, quartz, and potassium feldspar; average contents of these minerals are 33,9 , and 56 percent, respectively, as determined by modal analyses of 10 stained slabs (fig. 15); the color index is 2. The modal quartz content of this rock seems low considering its chemical composition (table 1), but this may be a function of the difficulties encountered in performing modal analyses of fine-grained rocks such as this.

Quartz, albite, and potassium feldspar form scarce anhedral phenocrysts $1-2 \mathrm{~mm}$ in diameter. The fluid inclusion content of quartz is low. Most of the inclusions are about 10 microns in diameter although some are 50 microns in diameter. The inclusions are vapor dominated. Potassium feldspar phenocrysts are perthitic and partly altered to sericite. Albite is polysynthetically
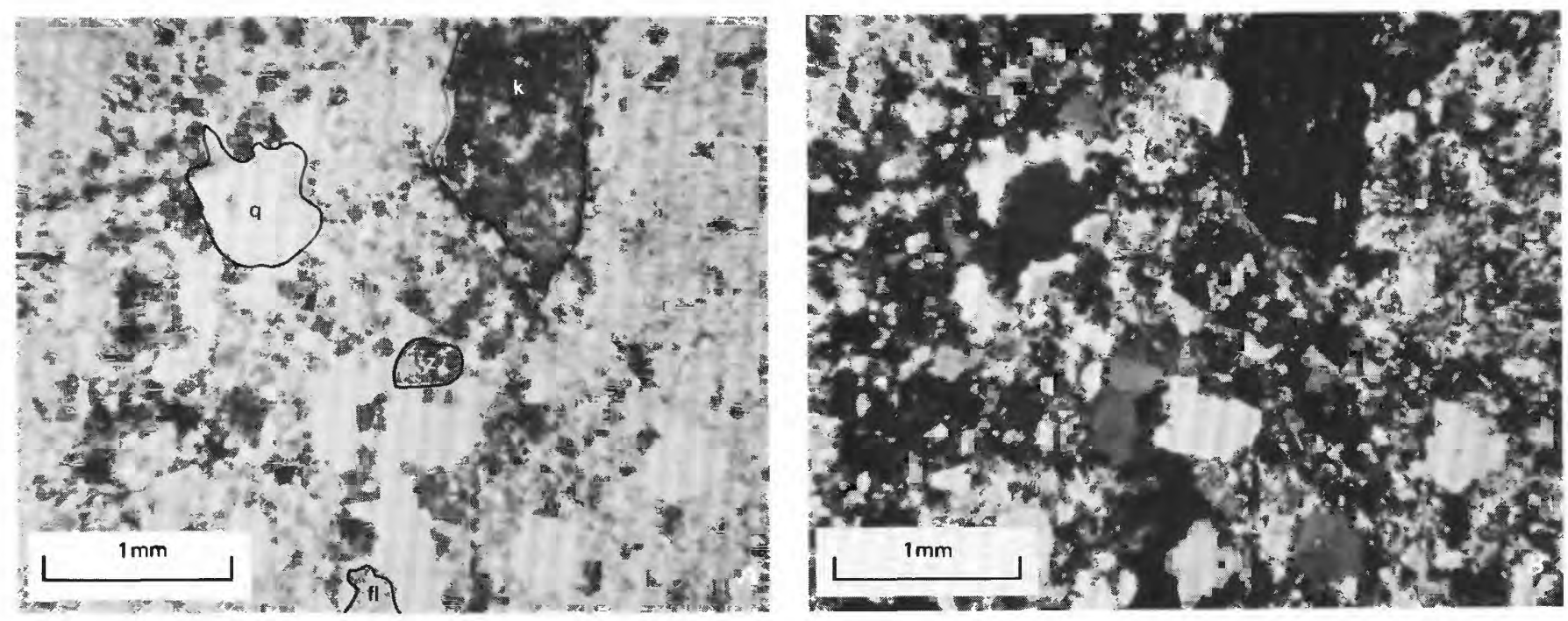

FIGURE 14. Photomicrographs of the Hadhir aplite showing the fine-grained allotriomorphic granular intergrowth of quartz and the feldspars. Grains of quartz (q), zinnwaldite (z), fluorite (fl), and a phenocryst of perthite are indicated. $A$, Uncrossed nicols; $B$, Crossed nicols. 


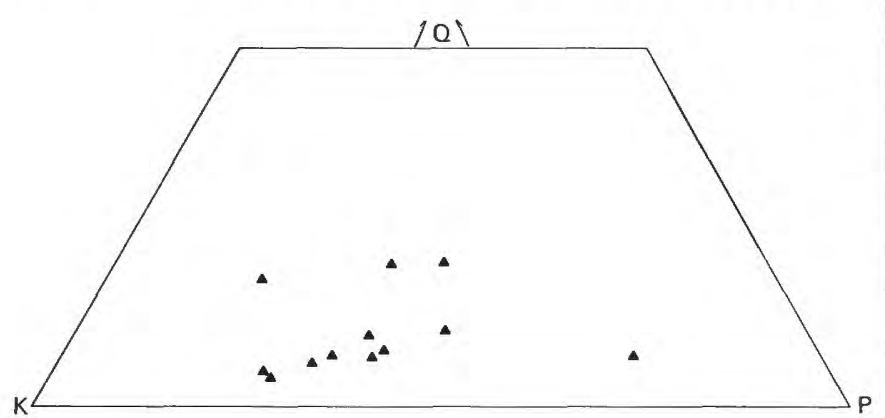

FIGURE 15. Ternary quartz-potassium feldspar-plagioclase (QKP) diagram showing the modal composition of the Hadhir aplite; the sum of $Q, K$, and $P$ is normalized to 100 percent. Each plotted point represents a modal analysis (between 300 and 700 points counted on a stained slab measuring at least $50 \mathrm{~cm}^{2}$ ) for a single sample. Albite is counted as plagioclase so that the ratio of albite to potassium feldspar is discernible. Figure can be converted to a Streckeisen (1976) diagram by replotting points on the Q-K sideline of the ternary diagram, at the $Q$ content indicated for each plotted point.

twinned. Biotite and Fe-Li mica form scarce anhedral to subhedral crystals as much as $1 \mathrm{~mm}$ long. Biotite is partly altered to clay minerals and opaque oxides in many samples and is pleochroic from light tan to dark reddish brown. The Fe-Li mica is weakly pleochroic from colorless to very light brown and is probably zinnwaldite. Fluorite, the principal accessory phase, forms anhedral grains $0.5-0.8 \mathrm{~mm}$ in diameter. Very small euhedral grains of zircon were identified as inclusions in biotite. The groundmass is an allotriomorphic granular, locally micrographic, intergrowth composed of quartz and alkali feldspar. Irregularly shaped, quartz-filled miarolitic cavities $0.5-2 \mathrm{~mm}$ in diameter are present.

\section{PEgMATITE}

The pegmatite is composed of potassium feldspar and milky-white quartz in graphic intergrowth. It is characterized by very coarse, variable grain size. Individual crystals of quartz and potassium feldspar are 10-20 cm in diameter. Coarse-grained fayalite, such as that reported in pegmatitic segregations of other highly evolved, alkalic plutonic rocks (Deer and others, 1966) forms euhedral, bladed, black crystals $2-10 \mathrm{~cm}$ long that occur interstitially. No other mafic silicates or accessory minerals were identified in the pegmatite. The pegmatite zone is composed of a series of adjacent or nearly adjacent pods set in a matrix of layered aplite.

\section{FAWWARAH ALKALI-FELDSPAR GRANITE}

The equigranular Fawwarah alkali-feldspar granite is very light gray, medium grained, and allotriomorphic granular (fig. 16). The felsic constituents are albite, quartz, and microcline. Average contents of these minerals are 25,33 , and 38 percent, respectively, as determined by modal analyses of 42 stained slabs (fig. 17 ); color index is 4 . Miarolitic cavities, $0.5-2 \mathrm{~mm}$ in diameter, partially filled by quartz, were identified in some samples.

Quartz forms subround anhedral grains 2-3 $\mathrm{mm}$ in diameter that contain a small number of fluid inclusions. The inclusions are 5-10 microns in diameter and their contents are liquid dominated. Microcline is weakly perthitic and forms anhedral to subhedral grains that are 2-3 mm long. Some grains poikilitically enclose grains of albite and quartz. Both lamellar and patch perthite patterns were identified. Some potassium feldspar grains are gridiron twinned while others are Carlsbad twinned. The plagioclase is polysynthetically twinned, unzoned albite that forms anhedral to subhedral laths 1.5-3 $\mathrm{mm}$ long; these are interstitial to quartz and microcline.

An Fe-Li mica and rare biotite are constituents of the Fawwarah alkali-feldspar granite. The Fe-Li mica, probably zinnwaldite, forms subhedral interstitial grains 0.5-1.5 mm long that are pleochroic from nearly colorless to either very light brown or very pale bluish green. Zinnwaldite is scarce in samples that contain biotite. Biotite also forms subhedral interstitial grains $0.5-1.5 \mathrm{~mm}$ long and is pleochroic from light yellow to very dark reddish brown. Biotite, and to a lesser extent zinnwaldite, contain very fine grained inclusions of zircon. A trace amount of zircon is present as very small subhedral crystals in the groundmass. Other accessory minerals include fluorite and topaz; some samples contain both of these fluorine-bearing phases. Fluorite, 0.3-1 modal percent, forms subhedral, purpletinged grains $0.5-1 \mathrm{~mm}$ in diameter and wormy interstitial grains that are commonly associated with the micas. Topaz, 0.1-0.5 modal percent, forms colorless, wormy crystals in the groundmass although it also forms scarce subhedral grains $0.5-2 \mathrm{~mm}$ in diameter. Secondary calcite fills intergranular fractures in some samples.

\section{DIKES}

The dikes within the southwest part of the ring complex are equigranular, very fine grained, and allotriomorphic granular. They are principally composed of intergrown quartz and alkali feldspar and contain trace amounts of opaque oxides. Correlation of the dikes with any of the ring complex componentd has not been possible because they were not studied in detail and only limited petrographic data are available. 

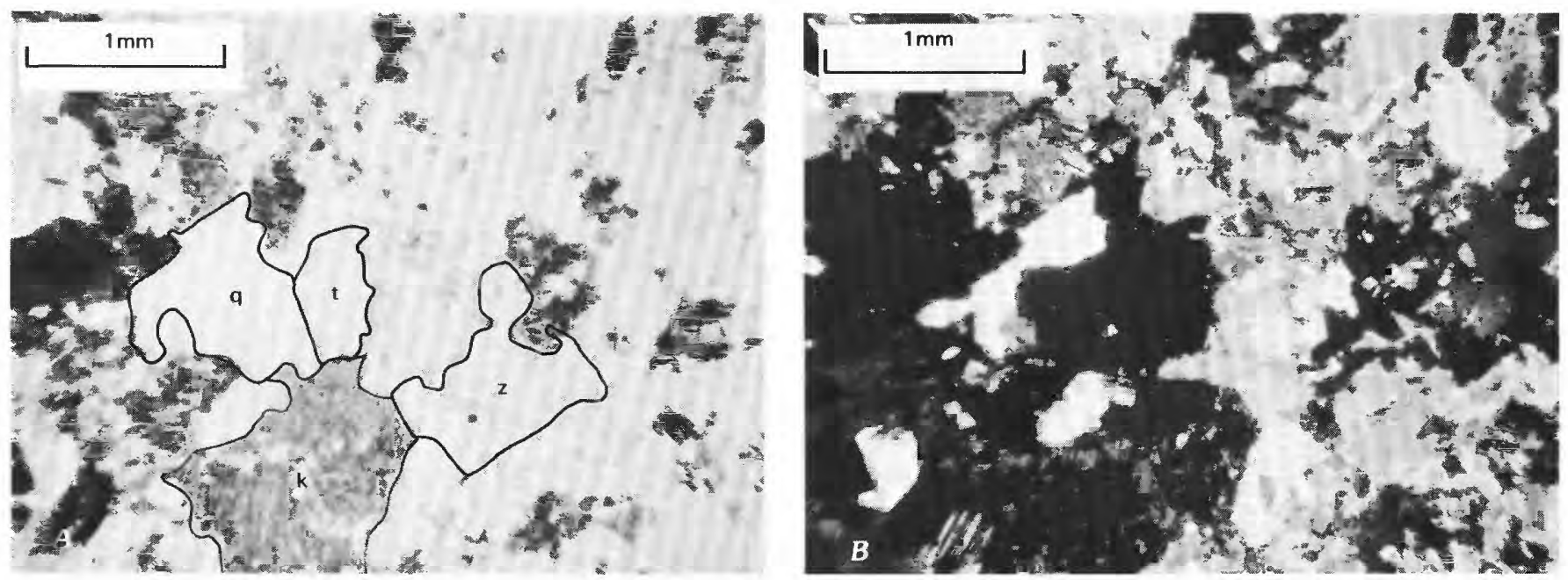

FIGURE 16. Photomicrographs of the Fawwarah alkali-feldspar granite showing the medium-grained allotriomorphic granular intergrowth of quartz and the feldspars. Grains of topaz (t), quartz (q), zinnwaldite (z), and potassium feldspar (k) are indicated. $A$, Uncrossed nicols; $B$, Crossed nicols.

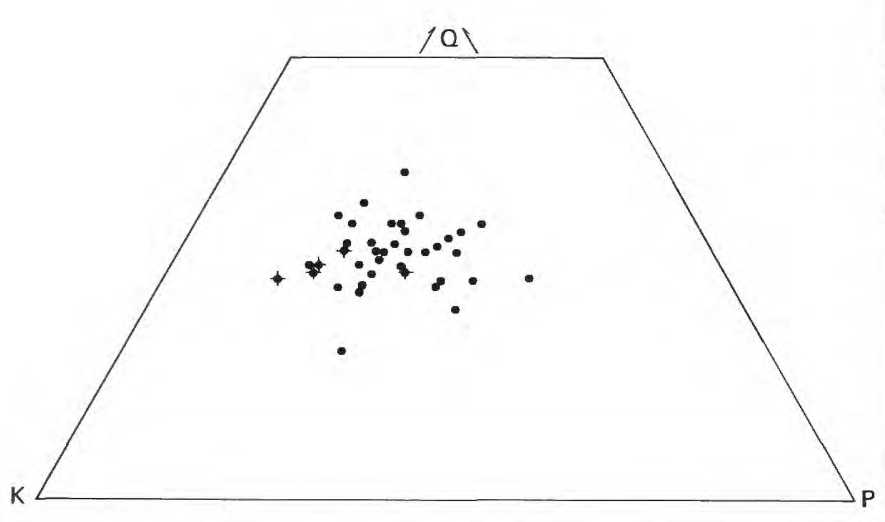

FIGURE 17. Ternary quartz-potassium feldspar-plagioclase (QKP) diagram showing the modal composition of the Fawwarah alkalifeldspar granite (dots) and the proto-Fawwarah alkali-feldspar granite (dots with plusses); the sum of $Q, K$, and $P$ is normalized to 100 percent. Each plotted point represents a modal analysis (between 300 and 700 points counted on a stained slab measuring at least $50 \mathrm{~cm}^{2}$ ) for a single sample. Albite is counted as plagioclase so that the ratio of albite to potassium feldspar is discernible. Figure can be converted to a Streckeisen (1976) diagram by replotting points on the $\mathrm{Q}-\mathrm{K}$ sideline of the ternary diagram, at the $\mathrm{Q}$ content indicated for each point.

\section{GREISEN}

Incomplete greisen is inequigranular, medium grained, and hypidiomorphic granular and is composed of quartz, zinnwaldite, and topaz (fig. 18). Anhedral quartz grains 2-4 $\mathrm{mm}$ in diameter display slightly undulatory extinction. Fluid inclusions 3-5 microns in diameter with somewhat variable liquid-vapor ratios are fairly abundant in quartz. Abundant, anhedral to subhedral flakes of zinnwaldite 3-5 $\mathrm{mm}$ long are colorless to pale rosy tan and are slightly altered to clay minerals. Abundant, anhedral topaz grains $0.5-1.5 \mathrm{~mm}$ in diameter contain few fluid inclusions. A trace amount of untwinned, anhedral albite and a trace amount of cassiterite, in color-zoned grains $0.1-0.2 \mathrm{~mm}$ in diameter, are present. The translucent, brown grains of cassiterite are included in grains of zinnwaldite or form discrete grains. Euhedral cubes of pyrite and subhedral to euhedral grains of sphalerite form fine grains that compose up to 1 percent of the incomplete greisen. Trace amounts of finegrained galena and wolframite also occur in incomplete greisen. An unidentified opaque mineral, apparently exsolved from zinnwaldite, occurs in one sample.

A variant of incomplete greisen occurs as small pods peripheral to the main, intensely mineralized greisen. This medium-grained, allotriomorphic inequigranular rock consists primarily of yellow-green zinnwaldite and quartz. Anhedral quartz grains are 1.5-3 $\mathrm{mm}$ in diameter. Faintly pleochroic, light rosy-tan to colorless zinnwaldite forms anhedral to subhedral grains 3-4 $\mathrm{mm}$ long. Trace amounts of anhedral, untwinned albite, relict from the igneous protolith, were also identified. Hematite is also a trace constituent.

Another variant of the incomplete greisen occurs in small areas beneath complete greisen; the variant is composed of alkali-feldspar granite characterized by an argillically altered appearance and has a distinctive dusky-reddish color. Very fine grained hematite within albite, which is considerably more abundant in this variant, is the source of the characteristic color. Albite is also partly altered to very fine grained sericite and clay minerals. A trade amount of topaz was identified in this variant. 

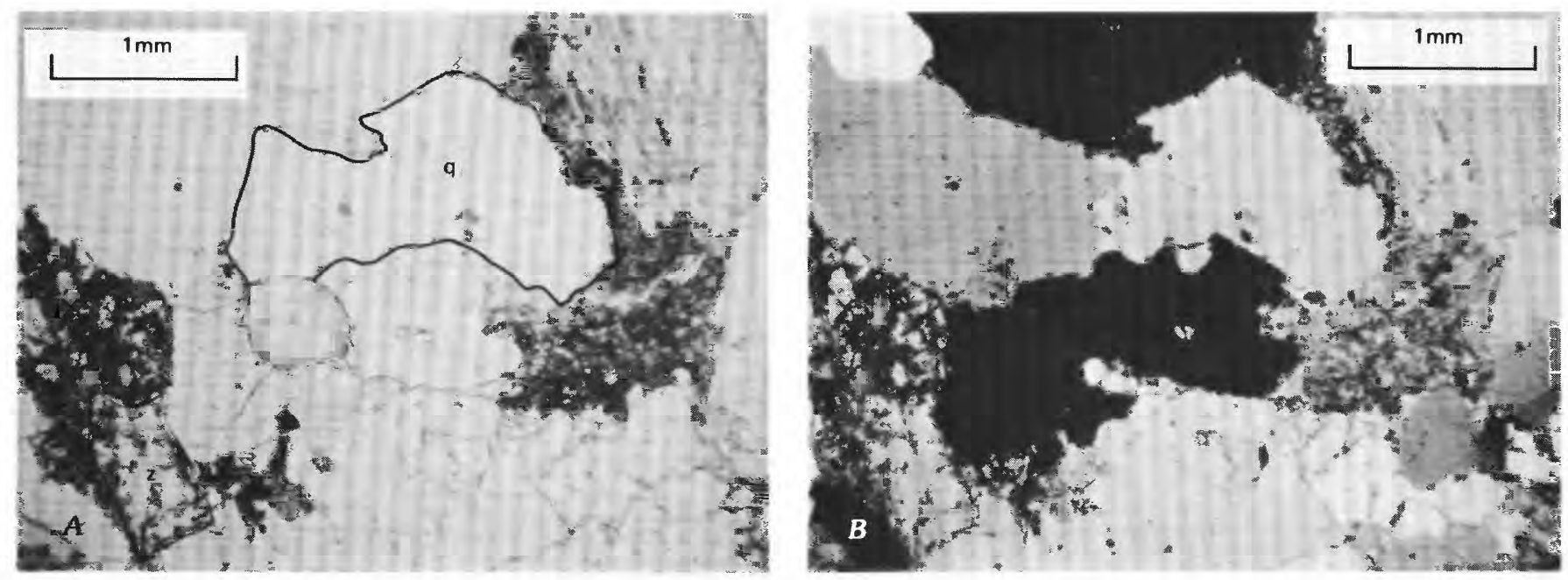

FIgURE 18. Photomicrographs of incompletely greisenized Fawwarah alkali-feldspar granite showing inequigranular, medium-grained, allotriomorphic granular intergrowth of quartz (q), zinnwaldite (z), and minor topaz (t). $A$, Uncrossed nicols; $B$, Crossed nicols.

Intensely tin-mineralized complete greisen is hydrothermally altered Fawwarah alkali-feldspar granite that is medium grained, inequigranular, and allotriomorphic granular and is composed of quartz, topaz, cassiterite, and trace amounts of opaque oxides and Fe-Li mica (fig. 19). Anhedral grains of quartz $1.5-3 \mathrm{~mm}$ in diameter contain fluid inclusions $10-20$ microns in diameter that have variable liquid-vapor ratios. Anhedral grains of topaz are $0.5-1.0 \mathrm{~mm}$ in diameter and contain scarce fluid inclusions 5 microns in diameter characterized by high liquid-vapor ratios. Abundant cassiterite forms anhedral grains 1-3 $\mathrm{mm}$ in diameter. These grains display one good cleavage, are simply twinned, and are characterized by oscillatory color zoning from nearly colorless to light grayish brown to medium yellowish brown. Fluid inclusions in cassiterite are extremely scarce. Trace amounts of fine-grained pyrite, sphalerite, galena, wolframite, and wolframoixiolite occur in complete greisen. Complete greisen contains scarce pods of dark reddish-brown gossany material, which are 2 to about $10 \mathrm{~cm}$ in diameter.

\section{GEOCHEMISTRY}

\section{ANALYTICAL METHODS}

X-ray Assay Laboratories, Ltd. (XRAL), Don Mills, Ontario, Canada, determined most major element compositions of the ring complex components by X-ray fluorescence; $\mathrm{FeO}$ and $\mathrm{CO}_{2}$ were determined by wet chemical methods. Rubidium (Rb), strontium (Sr), yttrium $(\mathrm{Y})$, zirconium $(\mathrm{Zr})$, niobium $(\mathrm{Nb})$, tin $(\mathrm{Sn})$, and barium $(\mathrm{Ba})$ were determined by the author using a Kevex 7000 multichannel, energy-dispersive, X-ray fluorescence spectrometer and ${ }^{109} \mathrm{Cd}$ and ${ }^{241} \mathrm{Am}$ radioisotope excitation sources. Fluorine (F) (selected ion electrode) and lithium (Li) (atomic absorption) were determined by the Directorate General of Mineral Resources (D.G.M.R.)/U.S.G.S. Laboratory, Jiddah, Saudi Arabia. The rare-earth elements (REE) and thorium (Th) determinations are neutron activation analyses performed by XRAL. XRAL determined uranium (U) abundances by delayed neutron counting. Oxygen isotope analyses were performed by M. D. Barton at the Geophysical Laboratory, Washington, D.C., using bromine pentafluoride extraction and mass spectrometry; results are relative to NBS-28. Lead, uranium, and thorium isotopic analyses were performed by L. B. Fischer, under the supervision of J. S. Stacey, in the isotope geology laboratory of the U.S. Geological Survey in Denver, Colorado. Analytical procedures and uncertainties for common lead determinations in potassium feldspar are described by Ludwig (1980) and Stacey and Stoeser (1983). The analytical procedure followed to obtain the U-Pb zircon age for the Fawwarah alkali-feldspar granite are described by Stacey and others (1984).

Mineral chemistry was determined by the author using a JEOL T300 scanning electron microscope with a Tracor Northern SiLi detector and utilizing the correction factors of Bence and Albee (1968). Analyses represent 200 second counts on single grains. Analyses of albite and the amphiboles were made using a focused 2-micron beam. Analyses of potassium feldspar and antiperthite were made using a defocused 50-micron beam. 

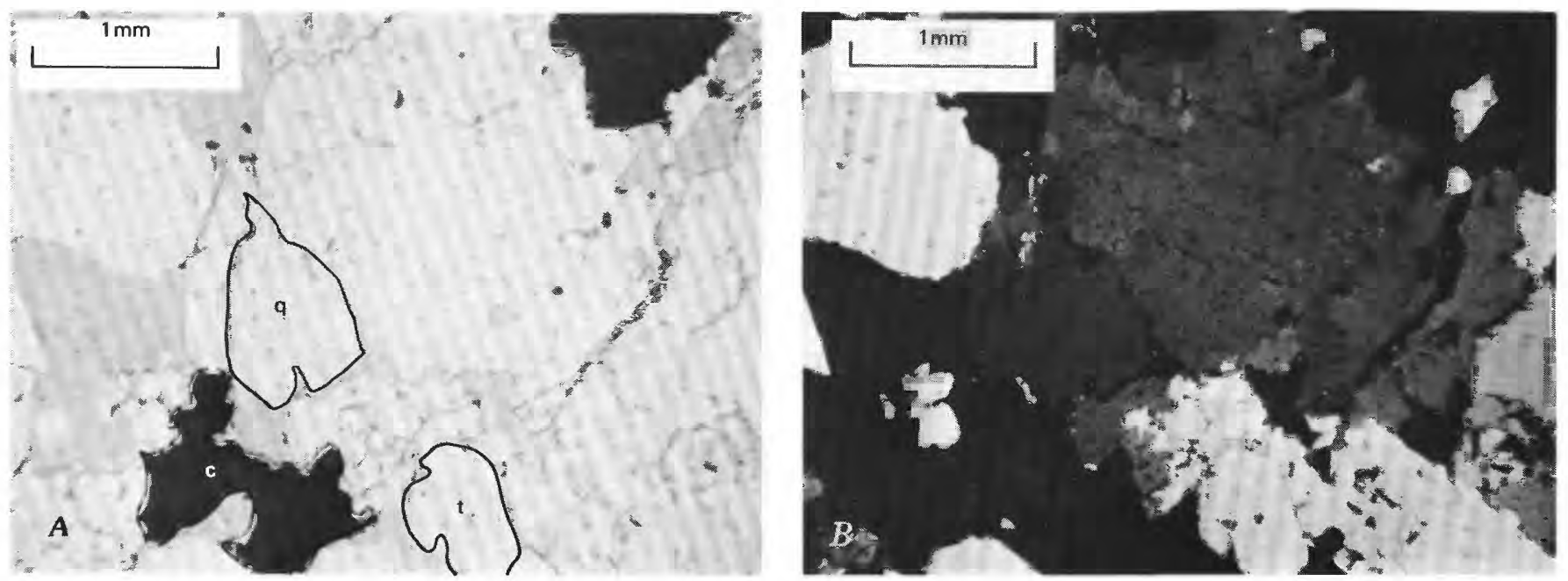

FIGURE 19. Photomicrographs of completely greisenized Fawwarah alkali-feldspar granite showing inequigranular, medium-grained, allotriomorphic granular intergrowth of quartz (q), topaz (t), and strongly colored cassiterite (c). $A$, Uncrossed nicols; $B$, Crossed nicols.

Iron $(\mathrm{Fe})$, magnesium $(\mathrm{Mg})$, calcium $(\mathrm{Ca})$, titanium (Ti), manganese (Mn), silver (Ag), arsenic (As), boron (B), barium $(\mathrm{Ba})$, beryllium $(\mathrm{Be})$, bismuth $(\mathrm{Bi})$, chromium $(\mathrm{Cr})$, copper $(\mathrm{Cu})$, molybdenum $(\mathrm{Mo})$, niobium $(\mathrm{Nb})$, nickel (Ni), lead (Pb), scandium (Sc), tin ( $\mathrm{Sn})$, strontium $(\mathrm{Sr})$, vanadium $(\mathrm{V})$, tungsten $(\mathrm{W})$, yttrium $(\mathrm{Y})$, zinc $(\mathrm{Zn})$, and zirconium (Zr) were determined (by semiquantitative emission spectrography) in mineralized samples by the D.G.M.R./U.S.G.S. laboratory. These data are reported as the midpoints, numbers in the series $1,1.5$, $2,3,5,7,10, \ldots$, of logarithmically spaced intervals. Quantitative determinations of rubidium (Rb), tungsten (W), tin (Sn), and arsenic (As) (by X-ray fluorescence) and fluorine (F) (by specific ion electrode) in mineralized samples were made by Computerised Analytical Laboratories (COMLABS) in Australia. The results of quantitative determinations were used in preference to those produced by semiquantitative spectrographic methods, in cases throughout this study for which data by both analytical methods are available.

\section{MARAGHAN LITHIC GRAYWACKE}

The composition of the Maraghan lithic graywacke is somewhat inhomogeneous (table 3), but this is characteristic of rapidly deposited detritus shed from a volcanic highland. The lithic fragment population in the graywacke is strongly dominated by clasts with volcanic textures. Thus, the chemistry of the lithic graywacke is treated as if it represents that of a volcanic rock, and it is classified accordingly. This approach provides an approximation of source-rock composition because it ignores the effects of chemical weathering and sorting phenomenon that may yield a sedimentary deposit that is chemically dissimilar to rock exposed in the provenance. The three samples of the lithic graywacke are subalkaline (Irvine and Baragar, 1971), in that they contain about 7 percent $\mathrm{Na}_{2} \mathrm{O}$ plus $\mathrm{K}_{2} \mathrm{O}$ at 65 percent $\mathrm{SiO}_{2}$. The composition of the graywacke is that of a soda-enriched volcanic rock, as indicated by the ternary proportions of normative or, an, and ab, and is transitional between that of dacite and tholeiitic andesite (fig. 20) (Irvine and Baragar, 1971). The graywacke is weakly corundum normative.

The contents of $\mathrm{Rb}, \mathrm{Sr}, \mathrm{Cr}, \mathrm{Zr}, \mathrm{U}$, and Th were determined in three samples of the Maraghan lithic graywacke (table 3). The graywacke contains amounts of these elements that are similar to the average value for shale determined by Turekian and Wedepohl (1961). The trace-element composition of the graywacke is that which one would expect for detrital rocks derived from volcanic rocks of intermediate composition (Hanson, 1978) and is surprisingly homogeneous.

REE data for three samples of the Maraghan lithic graywacke (table 3 ) indicate that the REE content of the sandstone is very homogeneous. The REE chondrite-normalized patterns are gently, negatively sloping and are characterized by a small, negative europium anomaly (fig. 21). The patterns are typical of those defined by volcanic rocks of intermediate composition.

\section{SILSILAH RING COMPLEX}

\section{MAJOR ELEMENTS}

The major-element chemistry of rocks from the Silsilah ring complex displays systematic smooth variation as a function of age. The oldest member of the complex, 
TABLE 3.-Major- and trace-element analyses and CIPW normative compositions for samples of the Maraghan lithic graywacke

[Major oxides and normative minerals in weight percent, trace elements in ppm. Leader indicates nil amount. Ferrous-ferric ratio adjusted prior to norm calculation along guidelines specified by Irvine and Baragar (1971)]

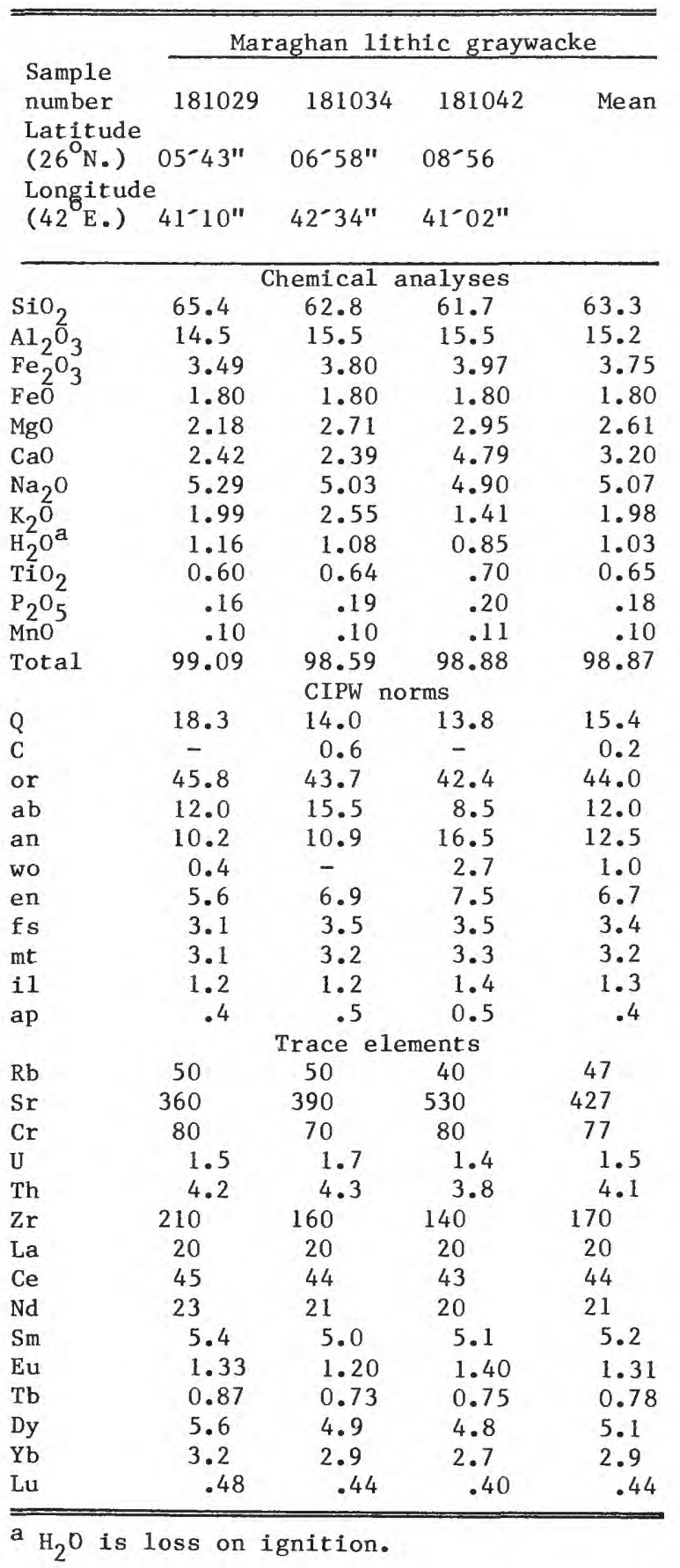

the alkaline dacite, has low silica contents and low differentiation indices whereas the youngest members of the complex, especially the Fawwarah alkali-feldspar granite, have high silica contents and high differentiation indices (table 1). $\mathrm{Al}_{2} \mathrm{O}_{3}$, total iron, $\mathrm{MgO}, \mathrm{CaO}$,
$\mathrm{TiO}_{2}, \mathrm{P}_{2} \mathrm{O}_{5}$, and $\mathrm{MnO}$ contents decrease systematically from the oldest to the youngest rocks; that is, from the low-silica to the high-silica rocks. $\mathrm{Na}_{2} \mathrm{O}$ contents are nearly constant. $\mathrm{K}_{2} \mathrm{O}$ contents increase with increasing silica content, reach a maximum in the alkali granite, and then decrease slightly with increasing silica (fig. 22). Fluorine contents increase with increasing silica contents. Calculated $\mathrm{Na}_{2} \mathrm{O} / \mathrm{K}_{2} \mathrm{O}$ ratios vary discontinuously between components of the complex.

Modal classification of the alkaline dacite and comendite was not possible because of their fine grain-size. Consequently, these rocks are treated as volcanic rocks

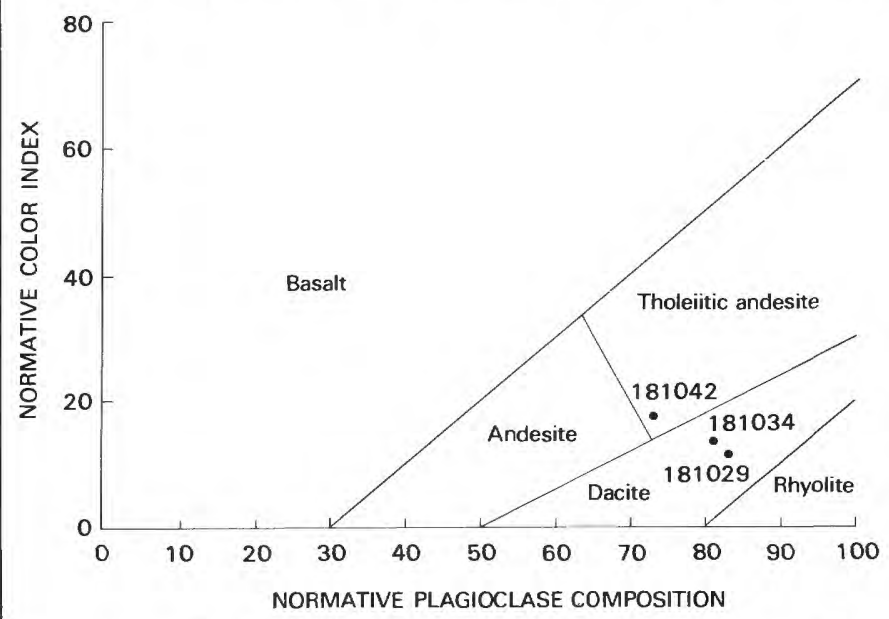

Figure 20. Plot of normative color index $(=\mathrm{ol}+\mathrm{di}+\mathrm{hy}+\mathrm{mt}+\mathrm{il}+\mathrm{hm})$ versus normative plagioclase composition $(=100 \times(a b+5 / 3 \times n e) /$ (an $+a b+5 / 3 \times n e))$ for three samples of the Maraghan lithic graywacke. Compositional field boundaries identified by Irvine and Baragar (1971) are shown.

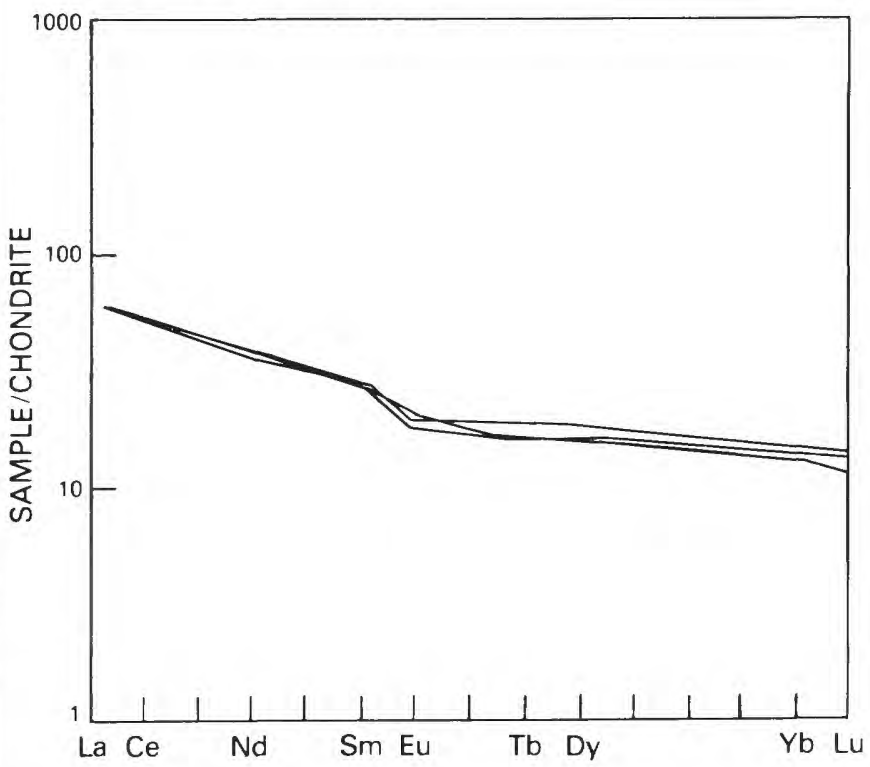

FIGURE 21. Chondrite-normalized rare-earth-element patterns for three samples of the Maraghan lithic graywacke. 


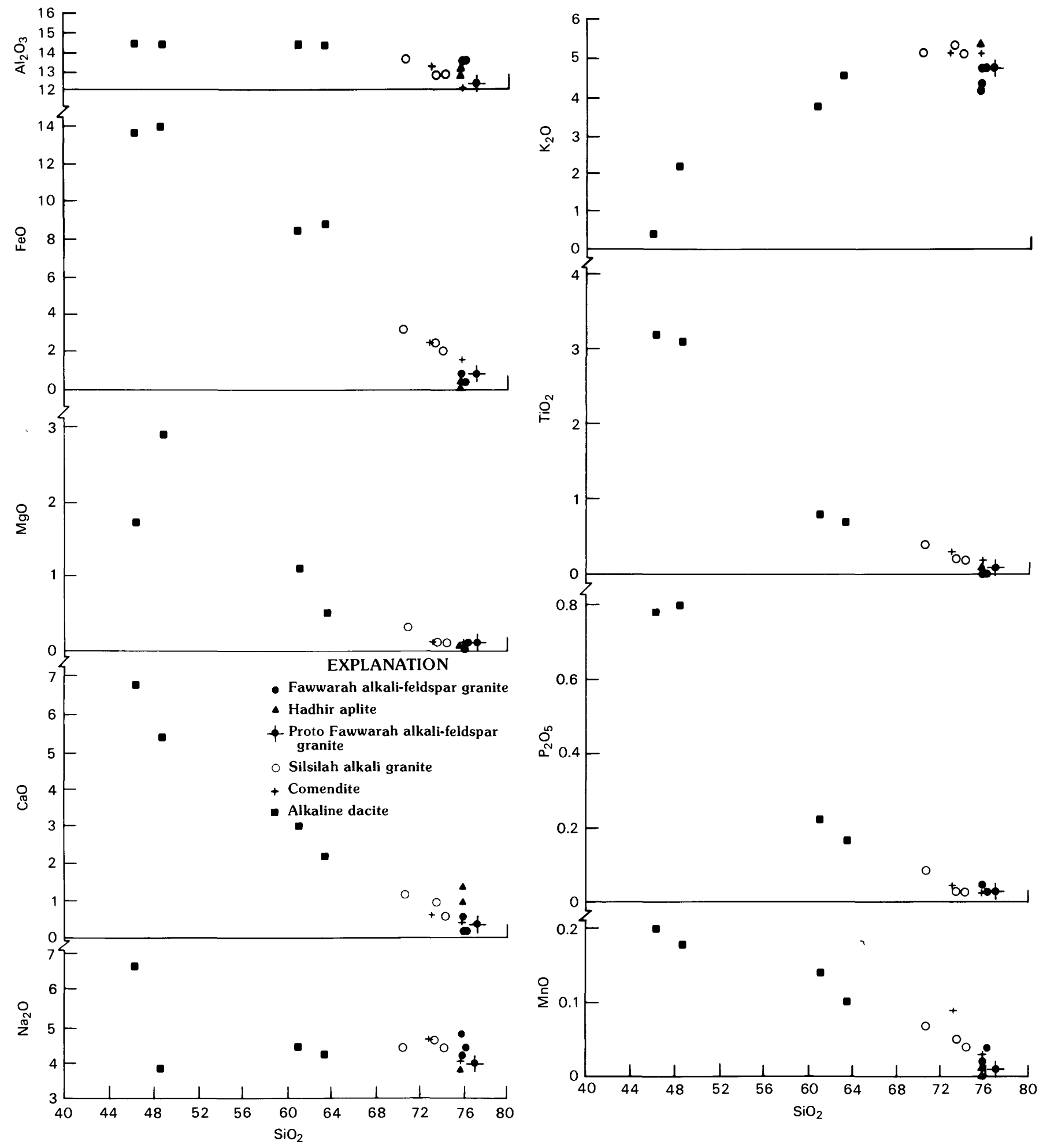

FIGURE 22. Harker variation diagrams showing the chemical variation exhibited by rocks of the Silsilah ring complex. Analyses normalized to 100 percent (anhydrous) before plotting.

and classified on the basis of their chemistry, using the scheme of Irvine and Baragar (1971). They represent a wide compositional range (table 1). Samples 181028 , 181956, 181924, and 181928 are metaluminous and follow an iron-enrichment trend (fig. 23) similar to that displayed by the rocks of the Skaergaard Intrusion (Wager and Deer, 1939). The first two samples contain about 6.5 percent $\mathrm{Na}_{2} \mathrm{O}$ plus $\mathrm{K}_{2} \mathrm{O}$ at 47 percent $\mathrm{SiO}_{2}$ 


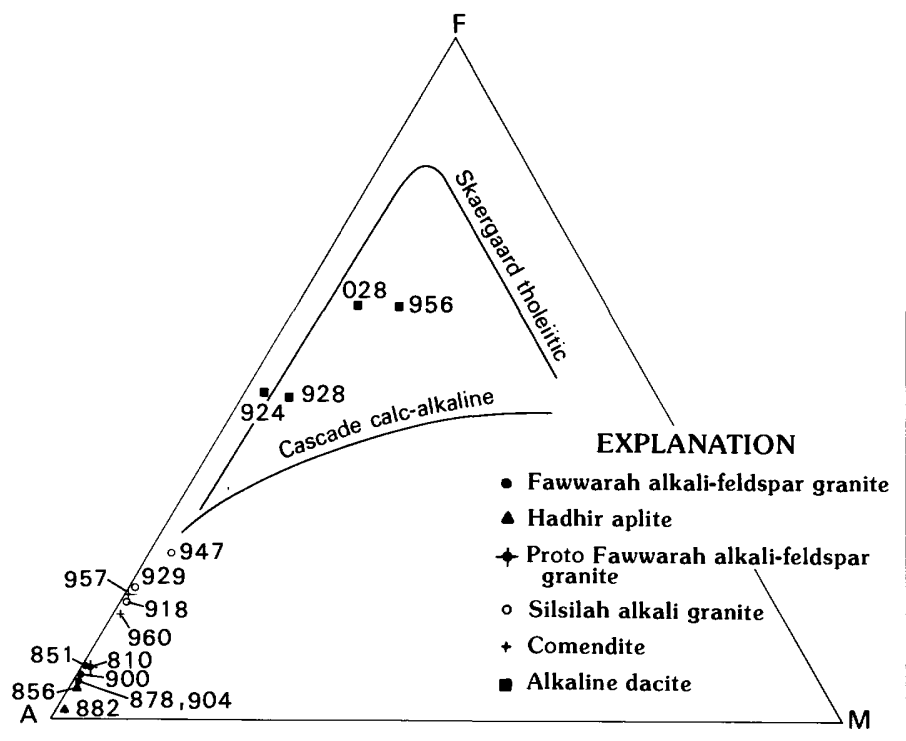

FIGURE 23. Ternary alkali-iron-magnesium (AFM) diagram (in weight percent) for samples of the Silsilah ring complex. $A=\left(\mathrm{Na}_{2} \mathrm{O}+\mathrm{K}_{2} \mathrm{O}\right)$, $\mathrm{F}=\left(\mathrm{FeO}+0.8998 \times \mathrm{Fe}_{2} \mathrm{O}_{3}\right), \mathrm{M}=\mathrm{MgO}$. Numbers next to data points are prefixed by 181 to obtain complete sample number; they correspond to entries in table 1. Trend lines from Irvine and Baragar (1971).

and so are alkaline. The ternary proportions of normative or, an, and ab in these samples indicate that these rocks are sodic-alkaline rocks. The second two samples contain about 8.5 percent $\mathrm{Na}_{2} \mathrm{O}$ plus $\mathrm{K}_{2} \mathrm{O}$ at 62 percent $\mathrm{SiO}_{2}$ and so have compositions transitional between those of alkaline and subalkaline rocks. The ternary proportions of normative or, an, and ab in these samples indicate that they are potassic-alkaline rocks. These four samples are characterized by high alkali element contents, high total iron content, and low silica content. Sample 181028 is a benmoreite, sample 181956 is a mugearite, sample 181928 is a trachyte, and sample 181924 is a tristanite (fig. 24). The tristanite and trachyte have compositions that are transitional between compositions of samples 181028 and 181956 and of samples 181957 and 181960 , which are examples of the comendite.

The chemistry of samples 181957 and 181960 support the hypothesis, based on petrographic inference, that these rocks are quenched equivalents of the Silsilah alkali granite. The samples are peralkaline and acmite normative. As suggested by Irvine and Baragar (1971), these rocks are classified using the scheme developed by Noble (1968) for acmite normative rocks; these rocks are comendite. The classification scheme more recently proposed by MacDonald (1975) for peralkaline, quartz-normative extrusive rocks also indicates that the composition of these rocks is comenditic. Of the ring complex components, the comendite has the highest

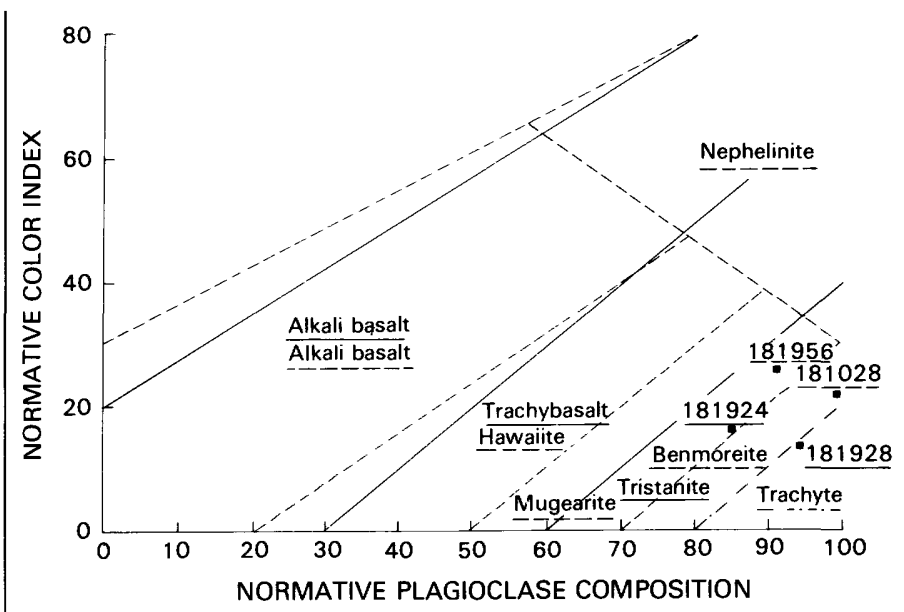

FIGURE 24. Plot of normative color index $(=\mathrm{ol}+\mathrm{di}+\mathrm{hy}+\mathrm{mt}+\mathrm{il}+\mathrm{hm})$ versus normative plagioclase composition $(=100 \times(a b+5 / 3 \times n e) /$ ( $a n+a b+5 / 3 \times n e)$ ) for four samples of the alkaline dacite. Compositional field boundaries identified by Irvine and Baragar (1971) are shown. Fields and composition names denoted by dashed lines pertain to sodic alkaline rocks whereas fields and composition names denoted by solid lines pertain to potassic alkaline rocks. The dashdot line shows the boundary of the trachyte field, which is the same for both types of alkaline rocks.

agpaitic index and is, therefore, the most peralkaline component.

Major-element analyses for the three principal constituents of the ring complex-the alkali granite, aplite, and alkali-feldspar granite-indicate that these are highly evolved rocks (table 1). The Silsilah alkali granite is weakly peralkaline and acmite normative. The Silsilah alkali granite is slightly more evolved than low-calcium granite, as indicated by differentiation indices (table 1). In particular, the alkali granite is characterized by greater contents of $\mathrm{Na}_{2} \mathrm{O}, \mathrm{K}_{2} \mathrm{O}, \mathrm{CaO}, \mathrm{TiO}_{2}$, and total iron and lower contents of $\mathrm{Al}_{2} \mathrm{O}_{3}, \mathrm{MgO}$, and $\mathrm{P}_{2} \mathrm{O}_{5}$. The Hadhir aplite is metaluminous whereas the Fawwarah alkali-feldspar granite is weakly peraluminous and corundum normative. Both the aplite and the alkalifeldspar granite have differentiation indices significantly greater than that of low-calcium granite, but the composition of the aplite is a little less evolved than that of the alkali-feldspar granite. These two rock types are characterized by very high contents of $\mathrm{SiO}_{2}$; high contents of $\mathrm{Na}_{2} \mathrm{O}, \mathrm{K}_{2} \mathrm{O}$, and $\mathrm{F}$; and very low contents of total iron, $\mathrm{MgO}, \mathrm{CaO}, \mathrm{TiO}_{2}, \mathrm{P}_{2} \mathrm{O}_{5}$, and $\mathrm{MnO}$. The $\mathrm{Q}$-abor normative compositions of these plutons are comparable to low total-pressure, minimum-melt compositions in the systems $\mathrm{SiO}_{2}-\mathrm{KAlSi}_{3} \mathrm{O}_{8}-\mathrm{NaAlSi}_{3} \mathrm{O}_{8}-\mathrm{H}_{2} \mathrm{O}$ (fig. 25) and normative an-ab-or (fig. 26).

The alkali granite, including its quenched comenditic equivalent, shows considerable $\mathrm{SiO}_{2}$ variation, whereas the Hadhir aplite and the Fawwarah alkali-feldspar are 


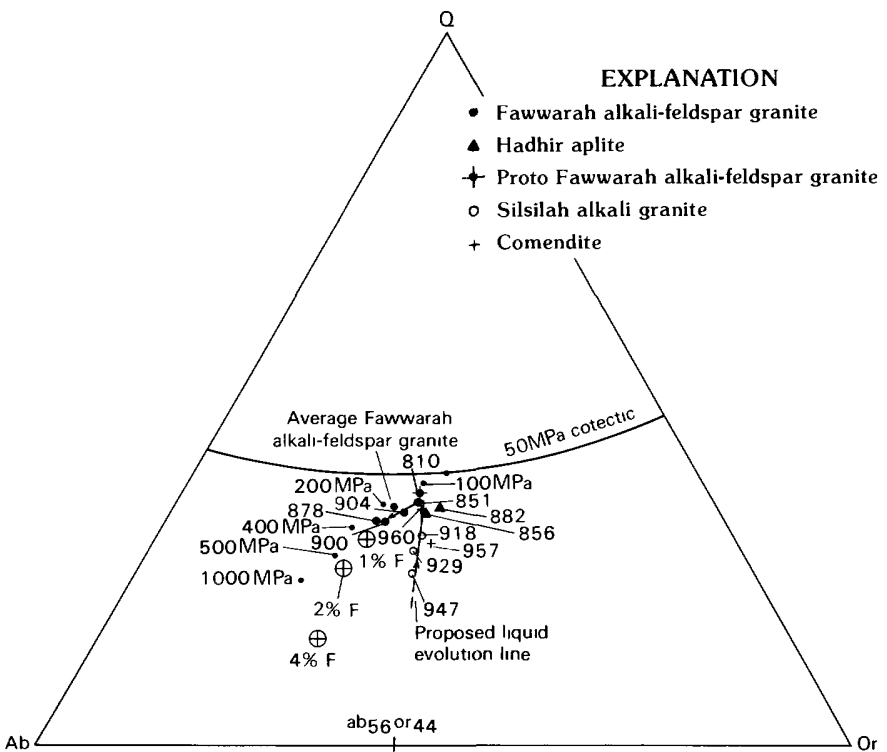

Figure 25. Normative quartz, albite, and orthoclase ternary diagram showing the composition of samples from the Silsilah ring complex. Numbers next to data points are prefixed by 181 to obtain complete sample number; they correspond to entries in table 1. Small dots, from top right to bottom left, represent the minimum melting compositions in the experimental system $\mathrm{SiO}_{2}-\mathrm{KAlSi}_{3} \mathrm{O}_{8}$ $\mathrm{NaAlSi}_{3} \mathrm{O}_{8}-\mathrm{H}_{2} \mathrm{O}$ for $\mathrm{P}\left(\mathrm{H}_{2} \mathrm{O}\right)=\mathrm{P}($ Total $)=50,100,200,400,500,1000$ megapascal (MPa); $100 \mathrm{MPa}=1 \mathrm{kbar}$ (Winkler and others, 1975). Circled pluses indicate minimum melting compositions at $100 \mathrm{MPa}$ with excess $\mathrm{H}_{2} \mathrm{O}$ and 1, 2, and 4 percent fluorine, as indicated (Manning, 1981).

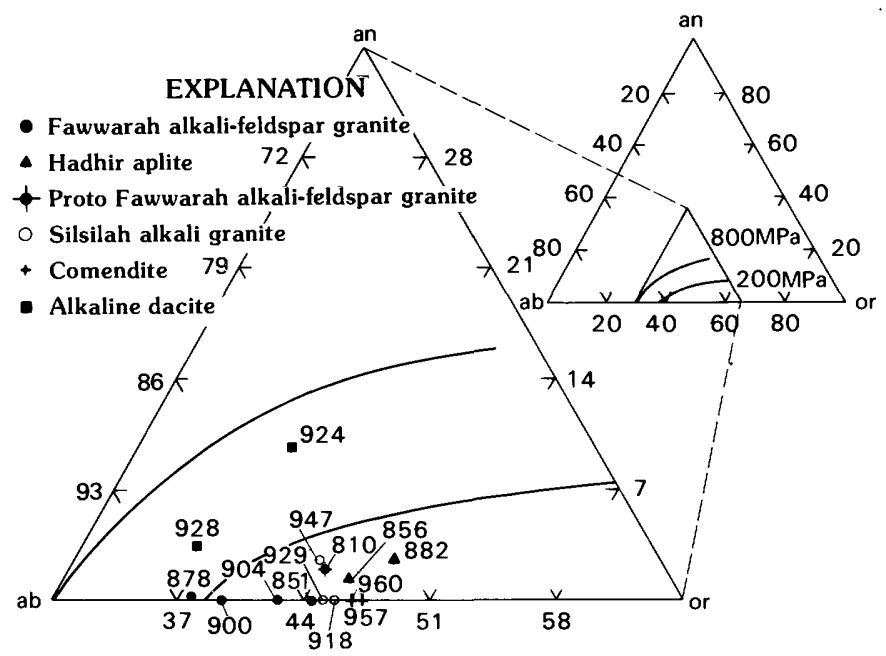

FIGURE 26. Ternary diagram showing the normative anorthite, albite, and orthoclase ( $a n, a b$, or) contents of samples from the Silsilah ring complex. Numbers next to data points are prefixed by 181 to obtain complete sample number; they correspond to entries in table 1. Curves show the position of water-saturated eutectic compositions at 200 and $800 \mathrm{MPa}$ (Whitney, 1975). Data for samples 181028 and 181956 are not plotted because they plot outside the inset ternary, toward the ab corner. characterized by more restricted $\mathrm{SiO}_{2}$ variation. Samples of the alkali granite contain from 70.8 to 75.3 weight percent $\mathrm{SiO}_{2}$, whereas samples of the aplite and alkali-feldspar granite contain from 74.1 to 76.9 weight percent $\mathrm{SiO}_{2}$.

The composition of the proto-Fawwarah alkalifeldspar granite (sample 181810, table 1) is more like that of the Hadhir aplite than the average composition for the Fawwarah alkali-feldspar granite itself. This observation suggests that the aplite is a quenched equivalent of the proto-Fawwarah alkali-feldspar granite and that the Fawwarah alkali-feldspar granite is a slightly more evolved phase of the magma represented by the aplite and the proto-Fawwarah alkali-feldspar granite.

Certain similarities exist between the major-element composition of the aplite and the alkali-feldspar granite and that of other highly evolved igneous rocks. The evolved major-element compositions, especially their degree of alumina saturation and their incompatible trace-element enrichment, are similar to features seen in metallogenically specialized granites (Tischendorf, 1977), $S$-type granites (White and Chappell, 1977), $A$ type granites (Collins and others, 1982), ilmenite-series granites (Ishihara, 1977), and topaz rhyolites (Burt and others, 1982). At many places in the world, these highly evolved rock types are associated with deposits of tin, tungsten, and other rare metals. In contrast, the peralkaline composition and less well-developed, incompatible trace-element enrichment characteristic of the Silsilah, alkali granite contrast with these other highly evolved rock types.

\section{TRACE ELEMENTS}

The trace-element composition of the alkaline dacite is distinctive (table 2). In particular, the alkaline dacite is depleted in the incompatible trace elements $\mathrm{Rb}, \mathrm{Y}$, $\mathrm{Nb}, \mathrm{F}, \mathrm{Li}, \mathrm{U}, \mathrm{Th}$, and $\mathrm{Sn}$ relative to their abundances in the other ring complex components. The alkaline dacite is notably enriched in barium and strontium relative to their abundances in other ring complex components and contains greater abundances of zirconium than either the aplite or alkali-feldspar granite. The trace-element composition of these rocks is similar to that of primitive, alkaline melts that include an anatectic upper-mantle component. In particular, the traceelement composition of these rocks is similar to that of less evolved members of the transitional basaltpantellerite sequence described by Barberi and others (1975).

The alkali granite, aplite, and alkali-feldspar granite can be distinguished on the basis of trace-element composition. Relative to the average low-calcium granite 
(table 2), the Silsilah alkali granite is depleted in $\mathrm{Li}, \mathrm{F}$, $\mathrm{Rb}, \mathrm{Sr}, \mathrm{Ba}$, and $\mathrm{Th}$; is enriched in $\mathrm{Zr}$ and $\mathrm{Nb}$; and may contain slightly greater abundances of $\mathrm{Y}, \mathrm{Sn}, \mathrm{U}$, and $\mathrm{Be}$. The $\mathrm{Rb} / \mathrm{Sr}$ ratio (fig. 27 ) for the alkali granite is about 3 and is, therefore, about twice that of lowcalcium granite. The trace-element chemistry of the comendite is nearly identical to that of the alkali granite (table 3), which confirms that it is a quenched equivalent of the alkali granite. Relative to the low-calcium granite, the Hadhir aplite is enriched in $\mathrm{Li}, \mathrm{F}, \mathrm{Rb}, \mathrm{Y}, \mathrm{Nb}, \mathrm{Sn}$, $\mathrm{Th}, \mathrm{U}$, and $\mathrm{Be}$ and depleted in $\mathrm{Sr}, \mathrm{Zr}, \mathrm{Ba}$, and $\mathrm{Cu}$; its $\mathrm{Rb} / \mathrm{Sr}$ ratio (fig. 27) is about 18 , about 10 times that of the low-calcium granite. The Fawwarah alkali-feldspar granite is enriched, relative to the low-calcium granite, in $\mathrm{Li}, \mathrm{F}, \mathrm{Rb}, \mathrm{Y}, \mathrm{Nb}, \mathrm{Sn}, \mathrm{Th}, \mathrm{U}$, and $\mathrm{Be}$ and depleted in $\mathrm{Sr}, \mathrm{Zr}, \mathrm{Ba}$, and $\mathrm{Cu}$; its $\mathrm{Rb} / \mathrm{Sr}$ ratio (fig. 27 ) is about 28 , about 17 times that of low-calcium granite. Traceelement enrichments and depletions identified in the Hadhir aplite are better developed in the Fawwarah alkali-feldspar granite. The degree to which the latter granite is enriched in some elements and depleted in others is extreme.

Tischendorf (1977) indicated that incompatible element enrichment, including combinations of $F, R b, \mathrm{Li}$, $\mathrm{Sn}, \mathrm{Be}, \mathrm{W}$, and $\mathrm{Mo}$, and high $\mathrm{Rb} / \mathrm{Sr}$ ratios, are diagnostic of metallogenically specialized granites. The topaz rhyolites described by Burt and others (1982) and $S$-type granites described by Chappell and White (1974) are characteristically enriched in these same elements. The ternary proportions of fluorine, lithium, and tin in the Silsilah alkali granite plot in the field defined for normal granites (Bailey, 1977), whereas the proportions of these elements in the Fawwarah alkali-feldspar granite plot in the field defined for stanniferous granites. The proportions of these elements in samples of the Hadhir aplite are transitional between those characteristic of normal and stanniferous granites.

Trace-element data for the Fawwarah alkali-feldspar granite and the Hadhir aplite are in part overlapping. The highest abundances of the incompatible elements in samples of the aplite are the same as values for the least incompatible-element enriched samples of the alkali-feldspar granite. Data for the alkali granite are distinctly different from those for the alkali-feldspar granite and the aplite but overlap with data for the comendite. Trace-element data for the alkaline dacite comprise discrete data fields that represent distinctly less evolved compositions.

\section{RARE-EARTH ELEMENTS}

The REE chondrite-normalized patterns (fig. 28A) for the alkaline dacite are gently, negatively sloping and

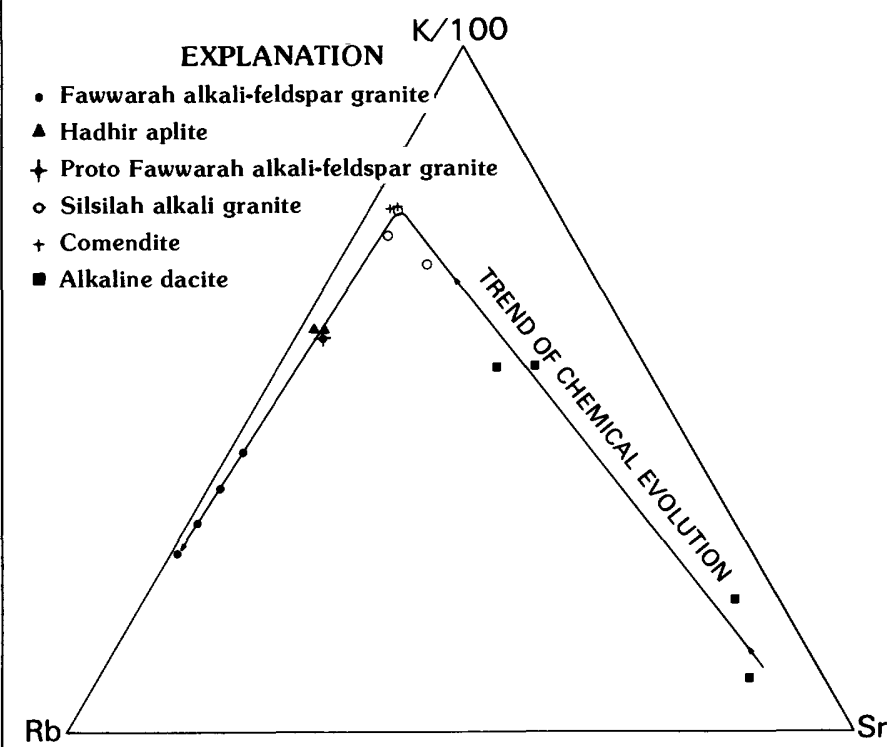

Figure 27. Ternary rubidium-strontium-potassium diagram for samples of the Silsilah ring complex.

most lack a europium anomaly. The patterns and total REE contents of these rocks (table 2) are similar to the patterns and REE contents of compositionally similar mugearites and benmoreites from the island of Reunion (Zielinski, 1975). The trachyte from the Silsilah ring complex is characterized by a small, negative europium anomaly.

The comendite has REE patterns identical to patterns for the Silsilah alkali granite. The sum of the nine REE increases from almost $200 \mathrm{ppm}$ in the alkaline dacite to about $450 \mathrm{ppm}$ in the comendite.

The sum of the nine REE (table 2) and chondritenormalized REE patterns for the Silsilah alkali granite are similar to those determined for peralkaline rocks in the northeastern Arabian Shield (Stuckless and others, 1982). Of the rocks that compose the ring complex, the Silsilah alkali granite has the highest average REE content, namely $474 \mathrm{ppm}$. The REE patterns (fig. $28 B$ ) have negative slopes, are parallel to patterns for the alkaline dacite, and are characterized by a moderate, negative europium anomaly.

The average value for the sum of REE in the protoFawwarah alkali-feldspar granite is 198 , which is intermediate between that of the alkali granite and the aplite. A single chondrite-normalized pattern for this unit has a slight, negative slope and a negative europium anomaly whose magnitude is greater than that observed for the alkali granite.

The average value for the sum of REE in the Hadhir aplite is $146 \mathrm{ppm}$, less than a third that of the Silsilah 

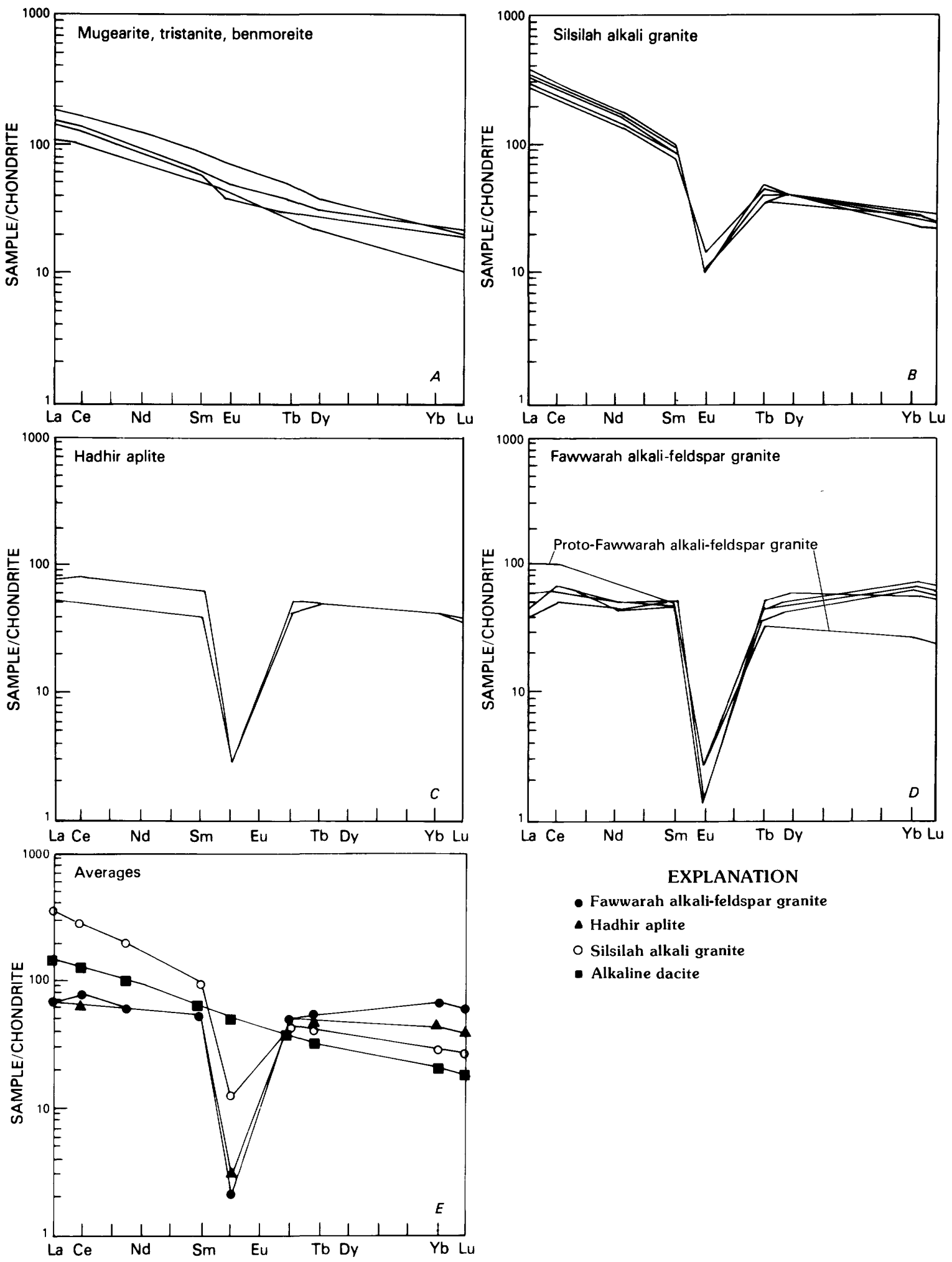

- Fawwarah alkali-feldspar granite

- Hadhir aplite

O Silsilah alkali granite

- Alkaline dacite

FIGURE 28. Chondrite-normailized rare-earth-element patterns for rocks of the Silsilah ring complex. Plotting symbols as in figure 22. $A$, Alkaline dacite; $B$, Silsilah alkali granite; $C$, Hadhir aplite; $D$, Fawwarah alkali-feldspar granite; $E$, Averages. 
alkali granite. Chondrite-normalized REE patterns for the Hadhir aplite (fig. 28C) are nearly flat but have a slight, negative slope and are characterized by a negative europium anomaly slightly greater than that observed in proto-Fawwarah alkali-feldspar granite.

The average sum of REE in the Fawwarah alkalifeldspar granite is about $155 \mathrm{ppm}$, whereas the sum of these REE in the low-calcium granite is $210 \mathrm{ppm}$ (Turekian and Wedepohl, 1961). Chondrite-normalized REE patterns for the Fawwarah alkali-feldspar granite (fig. $28 D$ ) are nearly flat and characterized by a large, negative europium anomaly. The patterns show some fluctuation of the light rare-earth elements (LREE) and the pattern for the heavy rare-earth elements (HREE) has a slight positive slope. Flat REE patterns and large, negative europium anomalies are characteristic of highly evolved graniroid rocks (Miller and Mittlefehldt, 1982). Average REE patterns for the ring complex components are plotted in figure $28 E$.

\section{OXYGEN ISOTOPES}

Oxygen isotope analyses of representative samples from the Silsilah ring complex were obtained for five quartz-whole rock pairs (table 4). The delta ${ }^{18} \mathrm{O}$ fractionation observed between quartz separates and wholerock pairs are small, and in all but one case the delta ${ }^{18} \mathrm{O}$ quartz is heavier. The small range of ${ }^{18} \mathrm{O}$ values for quartz samples from the alkali-feldspar granite suggests that these represent magmatic or near-magmatic values (Stuckless and others, 1984). The values for the Hadhir aplite and for the Fawwarah alkali-feldspar granite are in the upper third of the delta ${ }^{18} \mathrm{O}$ range defined for granites (Taylor, 1968). The average value for delta ${ }^{18} \mathrm{O}$ in three samples of the alkali-feldspar granite, 10.3, and the single value for the aplite, 10.5 , are both above the value of 10 defined by O'Neil and others (1977) as the demarcation between delta ${ }^{18} \mathrm{O}$-enriched $S$-type granites and delta ${ }^{18} \mathrm{O}$-depleted $I$-type granites. The single value for the Silsilah alkali granite is less than this value, however.

The oxygen-isotope data for samples of the ring complex are similar to values obtained for other peralkaline and peraluminous plutons of the northeastern Arabian Shield. The delta ${ }^{18} \mathrm{O}$-enriched character of the aplite and the alkali-feldspar granite is similar to that observed in the nearby Qutn alkali-feldspar granite, another peraluminous postorogenic pluton in the region (Stuckless and others, 1984). The lower delta ${ }^{18} \mathrm{O}$ value obtained for the Silsilah alkali granite is similar, although somewhat elevated relative to values determined for other peralkaline granitoid rocks in the region (Stuckless and others, 1984).

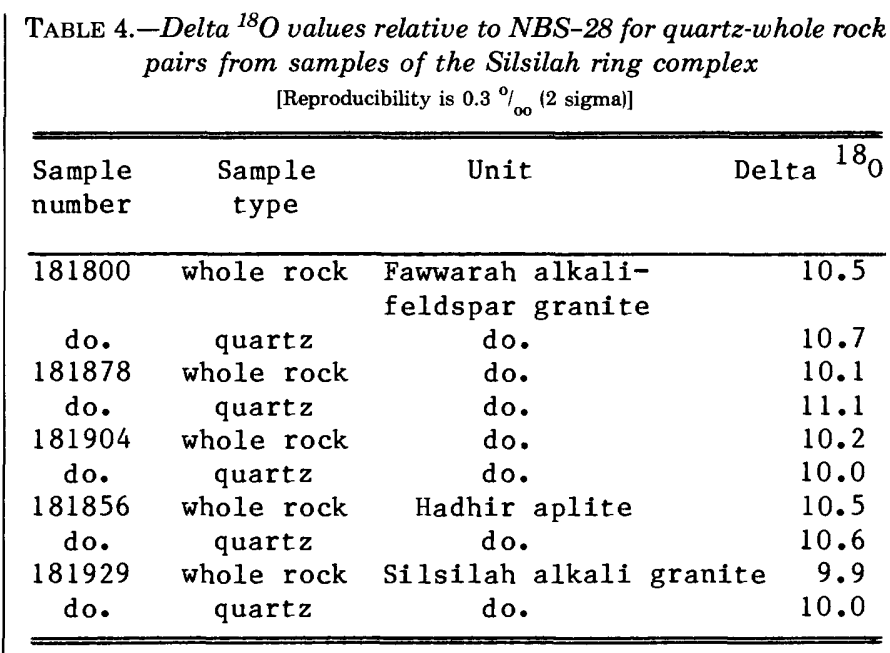

\section{MINERAL CHEMISTRY}

The feldspars in the Fawwarah alkali-feldspar granite are nearly end-member albite and orthoclase (table 5). The average structural formulas for albite and potassium feldspar in the alkali-feldspar granite are $\left(\mathrm{Na}_{0.92}\right.$, $\left.\mathrm{K}_{0.02}, \mathrm{Fe}_{0.05}, \mathrm{Ca}_{0.01}\right) \mathrm{AlSi}_{3} \mathrm{O}_{8}$ and $\left(\mathrm{K}_{0.88}, \mathrm{Na}_{0.05}, \mathrm{Fe}_{0.06}, \mathrm{Ca}_{0.01}\right)$ $\mathrm{AlSi}_{3} \mathrm{O}_{8}$, respectively. Stoichiometry suggests that iron is principally in the ferrous state and, therefore, is substituting, with minor amounts of calcium, for potassium and sodium in the feldspar lattices.

The antiperthite in the alkali granite is composed of nearly equal amounts of albite and orthoclase (table 6). The average composition of the antiperthite is $\left(\mathrm{Na}_{0.52}, \mathrm{~K}_{0.41}, \mathrm{Fe}_{0.06}, \mathrm{Ca}_{0.01}\right) \mathrm{AlSi}_{3} \mathrm{O}_{8}$. Iron is principally in the ferrous state, as was determined for the feldspars in the alkali-feldspar granite, and substitutes, with minor quantities of calcium, for potassium and sodium.

Chemical analyses of amphibole grains in the Silsilah alkali granite and comendite (table 7) indicate that they are composed of katophorite and arfvedsonite, respectively. D. B. Stoeser (written commun., 1984) has determined the composition of sodium-bearing amphiboles in peralkaline rocks of the Arabian Shield. His studies show that these amphiboles can be properly classified on the basis of the ratio of atomic calcium to atomic silicon in structural formulas. He identifies a smooth variation trend on an atomic calcium-silicon plot between amphiboles classified as ferroedenite, katophorite, and arfvedsonite (fig. 29). Analyses for amphibole in the Silsilah alkali granite plot along the part of this trend for which compositions are classified as katophorite whereas analyses for amphibole in the comendite plot in the arfvedsonite field.

Three mineral separates of $\mathrm{Fe}$-Li mica from the alkalifeldspar granite and one from a sample of incomplete 
TABLE 5.-Structural formulas for feldspars in samples of the Fawwarah alkali-feldspar granite [Number following hyphen in sample number indicates grain-pair designation within that sample; $\mathrm{k}$ in mineral column indicates potassium feldspar and a indicates albite; s.d. is standard deviation]

\begin{tabular}{|c|c|c|c|c|c|c|c|c|}
\hline \multirow[b]{2}{*}{ Sample } & \multirow[b]{2}{*}{ Mineral } & \multicolumn{2}{|c|}{ Structural } & \multirow{2}{*}{$\begin{array}{c}\text { formula } \\
\mathrm{Si}\end{array}$} & \multirow{2}{*}{$\begin{array}{c}\text { based } \\
\text { K }\end{array}$} & \multicolumn{2}{|c|}{ on 8 oxygens } & \multirow[b]{2}{*}{ Mol percent $a b$} \\
\hline & & $\mathrm{Na}$ & A1 & & & $\mathrm{Ca}$ & $\mathrm{Fe}$ & \\
\hline $181878-1$ & $\mathrm{k}$ & 0.053 & 1.005 & 2.979 & 0.884 & 0.008 & 0.058 & 5.3 \\
\hline--- do. -- & $\mathrm{a}$ & .915 & 1.052 & 2.951 & .023 & .009 & .041 & 92.5 \\
\hline $181878-2$ & $\mathrm{k}$ & .049 & 1.031 & 2.956 & .883 & .011 & .064 & 4.9 \\
\hline--- do. -- & $a$ & .916 & 1.054 & 2.950 & .020 & .000 & .051 & 92.8 \\
\hline $181878-3$ & $\mathrm{k}$ & .040 & 1.020 & 2.964 & .889 & .015 & .062 & 4.0 \\
\hline-- do. -- & $a$ & .950 & 1.044 & 2.947 & .018 & .008 & .049 & 92.7 \\
\hline $181878-4$ & $\mathrm{k}$ & .063 & 1.024 & 2.971 & .852 & .009 & .055 & 6.5 \\
\hline--- do. -- & $a$ & .918 & 1.039 & 2.954 & .027 & .015 & .047 & 91.1 \\
\hline $181878-5$ & $\mathrm{k}$ & .026 & 1.028 & 2.963 & .890 & .013 & .061 & 2.6 \\
\hline-- do. -- & $\mathrm{a}$ & .960 & 1.019 & 2.958 & .022 & .012 & .052 & 96.9 \\
\hline 181878-mean & $\mathrm{k}$ & .045 & 1.022 & 2.967 & .880 & .011 & .060 & 4.7 \\
\hline--- do. - s.d. & $\mathrm{k}$ & .016 & .010 & .009 & .016 & .003 & .004 & 1.5 \\
\hline 181878-mean & $a$ & .932 & 1.042 & 2.952 & .022 & .009 & .048 & 93.2 \\
\hline$--d_{0}-s . d$. & $a$ & .021 & .014 & .004 & .003 & .006 & .004 & 2.2 \\
\hline $181900-1$ & $\mathrm{k}$ & .083 & 1.016 & 2.978 & .829 & .000 & .063 & 8.5 \\
\hline--- do. -- & a & .958 & 1.041 & 2.946 & .022 & .005 & .051 & 92.5 \\
\hline $181900-2$ & $\mathrm{k}$ & .096 & 1.018 & 2.991 & .783 & .000 & .051 & 10.3 \\
\hline--- do. -- & a & .955 & 1.046 & 2.945 & .018 & .004 & .050 & 93.0 \\
\hline $181900-3$ & $\mathrm{k}$ & .099 & 1.011 & 2.982 & .811 & .005 & .060 & 10.1 \\
\hline--- do. -- & $a$ & .889 & 1.038 & 2.954 & .026 & .024 & .054 & 89.5 \\
\hline $181900-4$ & $\mathrm{k}$ & .030 & 1.045 & 2.955 & .864 & .005 & .069 & 3.1 \\
\hline--- do. -- & $a$ & .895 & 1.084 & 2.918 & .034 & .022 & .052 & 89.3 \\
\hline 181900 -mean & $\mathrm{k}$ & .077 & 1.023 & 2.977 & .823 & .003 & .061 & 8.0 \\
\hline- do.-s.d. & $\mathrm{k}$ & .032 & .015 & .015 & .034 & .003 & .008 & 3.4 \\
\hline $181900-$ mean & $a$ & .924 & 1.052 & 2.941 & .025 & .014 & .052 & 91.1 \\
\hline$---d o .-s \cdot d$ & $a$ & .037 & .021 & .016 & .007 & .011 & .002 & 1.9 \\
\hline $181904-1$ & $\mathrm{k}$ & .056 & 1.023 & 2.961 & .874 & .011 & .068 & 5.5 \\
\hline--- do. -- & $a$ & .936 & 1.069 & 2.932 & .022 & .012 & .040 & 92.6 \\
\hline $181904-2$ & $\mathrm{k}$ & .000 & 1.027 & 2.970 & .897 & .008 & .063 & 0.0 \\
\hline--- do. -- & $a$ & .964 & 1.046 & 2.940 & .022 & .009 & .049 & 92.4 \\
\hline $181904-3$ & $\mathrm{k}$ & .036 & 1.046 & 2.948 & .893 & .010 & .060 & 3.7 \\
\hline--- do. -- & $a$ & .924 & 1.053 & 2.940 & .029 & .007 & .057 & 90.9 \\
\hline $181904-4$ & $\mathrm{k}$ & .092 & 1.041 & 2.958 & .821 & .004 & .064 & 9.4 \\
\hline--- do. -- & $a$ & .918 & 1.056 & 2.944 & .025 & .007 & .048 & 92.0 \\
\hline $181904-5$ & k & .078 & 1.030 & 2.961 & .852 & .005 & .065 & 7.8 \\
\hline--- do. -- & $a$ & .956 & 1.063 & 2.930 & .021 & .007 & .051 & 92.4 \\
\hline 181904-mean & $\mathrm{k}$ & .052 & 1.033 & 2.960 & .867 & .008 & .064 & 5.3 \\
\hline--- do. -s.d. & $\mathrm{k}$ & .036 & .010 & .008 & .031 & .003 & .003 & 3.7 \\
\hline 181904-mean & a & .940 & 1.057 & 2.937 & .024 & .008 & .049 & 92.1 \\
\hline$---d o .-s . d$. & a & .020 & .009 & .006 & .003 & .002 & .006 & .7 \\
\hline $181911-1$ & $\mathrm{k}$ & .039 & .995 & 2.997 & .863 & .014 & .056 & 4.0 \\
\hline-- do. -- & a & .944 & 1.026 & 2.954 & .022 & .020 & .051 & 91.1 \\
\hline $181911-2$ & $\mathrm{k}$ & .036 & 1.020 & 2.969 & .889 & .000 & .069 & 3.6 \\
\hline--- do. -- & $\mathrm{a}$ & .933 & 1.031 & 2.961 & .020 & .008 & .046 & 93.0 \\
\hline $181911-3$ & $\mathrm{k}$ & .056 & 1.012 & 2.977 & .874 & .000 & .063 & 5.6 \\
\hline$---\mathrm{do} .--$ & a & .861 & 1.027 & 2.975 & .018 & .012 & .059 & 90.7 \\
\hline 181911-mean & $\mathrm{k}$ & .044 & 1.009 & 2.981 & .875 & .005 & .063 & 4.4 \\
\hline$--\mathrm{do} \cdot-\mathrm{s} \cdot \mathrm{d}$. & $\mathrm{k}$ & .011 & .013 & .014 & .013 & .008 & .007 & 1.1 \\
\hline 181911-mean & $a$ & .913 & 1.028 & 2.963 & .020 & .013 & .052 & 91.6 \\
\hline$--d o .-s . d$ & $a$ & .045 & .003 & .011 & .002 & .006 & .007 & 1.2 \\
\hline GRAND MEAN & $\mathrm{k}$ & .054 & 1.023 & 2.970 & .860 & .007 & .062 & 5.5 \\
\hline GRAND MEAN & a & .929 & 1.046 & 2.947 & .023 & .011 & .049 & 91.8 \\
\hline
\end{tabular}


TABLE 6.-Structural formulas for perthite in samples of the Silsilah alkali granite [Number following hyphen in sample number indicates grain designation within that sample; s.d. is standard deviation]

\begin{tabular}{|c|c|c|c|c|c|c|c|c|}
\hline \multirow[t]{2}{*}{ Sample } & \multicolumn{2}{|c|}{ Structural } & \multirow{2}{*}{$\begin{array}{c}\text { formula } \\
\mathrm{Si}\end{array}$} & \multirow{2}{*}{$\begin{array}{c}\text { based } \\
\mathrm{K}\end{array}$} & \multicolumn{2}{|c|}{ on 8 oxygens } & \multicolumn{2}{|c|}{ Mol percent } \\
\hline & $\mathrm{Na}$ & Al & & & $\mathrm{Ca}$ & $\mathrm{Fe}$ & $a b$ & or \\
\hline $181918-1$ & 0.465 & 0.996 & 2.974 & 0.450 & 0.009 & 0.009 & 49.8 & 48.2 \\
\hline $181918-2$ & .523 & .941 & 3.045 & .331 & .000 & .072 & 56.5 & 35.8 \\
\hline $181918-3$ & .554 & 1.029 & 2.968 & .349 & .005 & .065 & 56.9 & 35.9 \\
\hline $181918-4$ & .456 & 1.008 & 2.967 & .467 & .010 & .083 & 44.9 & 46.0 \\
\hline 181918-mean & .500 & .994 & 2.989 & .399 & .006 & .057 & 52.0 & 41.5 \\
\hline $181918-\mathrm{s} \cdot \mathrm{d}$ & .047 & .038 & 0.038 & .069 & .005 & .033 & 5.8 & $6 \cdot 6$ \\
\hline $181929-1$ & .673 & .990 & 2.982 & .291 & .006 & .063 & 65.2 & 28.2 \\
\hline $181929-2$ & .477 & 1.003 & 2.978 & .441 & .011 & .069 & 47.8 & 44.2 \\
\hline $181929-3$ & .413 & 1.024 & 2.954 & .523 & .022 & .066 & 40.3 & 51.1 \\
\hline $181929-4$ & .556 & .990 & 2.973 & .395 & .008 & .087 & 53.2 & 37.8 \\
\hline 181929-mean & .530 & 1.001 & 2.972 & .413 & .012 & .071 & 51.6 & 40.3 \\
\hline $181929-\mathrm{s} . \mathrm{d}$ & .112 & .016 & .012 & .097 & .007 & .011 & 10.5 & 9.7 \\
\hline GRAND MEAN & .515 & .998 & 2.981 & .406 & .009 & .064 & 51.8 & 40.9 \\
\hline
\end{tabular}

TABLE 7.-Structural formulas for amphiboles from the Silsilah ring complex [Number following hyphen in sample number indicates grain designation within that sample; s.d. is standard deviation]

\begin{tabular}{|c|c|c|c|c|c|c|c|c|c|}
\hline \multirow[b]{2}{*}{ Sample } & \multicolumn{9}{|c|}{ St ructural formula based on 23 oxygen } \\
\hline & $\mathrm{Na}$ & Mg & A1 & Si & K & $\mathrm{Ca}$ & $\mathrm{Ti}$ & $\mathrm{Mn}$ & $\mathrm{Fe}$ \\
\hline \multicolumn{10}{|c|}{ Amphibole from the Silsilah Alkali Granite } \\
\hline $181918-1$ & 1.233 & 0.000 & 0.725 & 7.632 & 0.236 & 0.929 & 0.151 & 0.051 & 4.632 \\
\hline $181918-2$ & 1.337 & .075 & .784 & 7.677 & .187 & .685 & .118 & .093 & 4.619 \\
\hline $181918-3$ & 1.434 & .124 & .683 & 7.568 & .221 & .944 & .098 & .069 & 4.678 \\
\hline 181918-mean & 1.335 & .066 & .731 & 7.626 & .215 & .853 & .122 & .071 & 4.643 \\
\hline $181918-\mathrm{s} \cdot \mathrm{d}$ & 0.101 & .063 & .051 & 0.055 & .025 & .145 & .027 & .021 & 0.031 \\
\hline $181929-1$ & .940 & .000 & .773 & 7.542 & .205 & 1.066 & .168 & .075 & 4.707 \\
\hline $181929-2$ & .767 & .104 & .746 & 7.524 & .217 & 1.046 & .159 & .090 & 4.783 \\
\hline $181929-3$ & 1.155 & .000 & .794 & 7.462 & .283 & 1.133 & .165 & .069 & 4.634 \\
\hline $181929-4$ & 1.155 & .067 & .823 & 7.494 & .221 & 1.046 & .157 & .092 & 4.571 \\
\hline 181929-mean & 1.004 & .026 & .784 & 7.506 & .232 & 1.073 & .162 & .082 & 4.674 \\
\hline $181929-\mathrm{s} \cdot \mathrm{d}$ & .188 & .052 & .033 & .035 & .035 & .041 & .005 & .011 & .092 \\
\hline \multicolumn{10}{|c|}{ Amphibole from the Comendite } \\
\hline $181957-3$ & 1.795 & .000 & .311 & 8.224 & .138 & .260 & .061 & .043 & 4.694 \\
\hline $181957-4$ & 2.279 & .000 & .045 & 8.454 & .041 & .000 & .012 & .000 & 4.837 \\
\hline $181957-5$ & 2.149 & .000 & .152 & 8.007 & .200 & .456 & .113 & .058 & 4.842 \\
\hline $181957-6$ & 2.090 & .000 & .133 & 8.275 & .071 & .185 & .050 & .013 & 4.872 \\
\hline $181957-7$ & 2.265 & .000 & .395 & 8.016 & .154 & .228 & .116 & .060 & 4.647 \\
\hline 181957-mean & 2.116 & .000 & .207 & 8.195 & .121 & .226 & .070 & .035 & 4.778 \\
\hline $181957-\mathrm{s} . \mathrm{d}$ & .175 & - & .127 & .168 & .057 & .146 & .040 & .024 & .090 \\
\hline
\end{tabular}

greisen have total iron contents, expressed as $\mathrm{Fe}_{2} \mathrm{O}_{3}$, that range between 13 and 19 percent. $\mathrm{Li}_{2} \mathrm{O}$ contents in these samples range between 3 and 6.5 percent. These compositions are diagnostic of zinnwaldite (Deer and others, 1966). Semiquantitative trace-element analyses obtained using a Kevex 7000 multichannel spectrometer indicate that this mica contains between 200 and $500 \mathrm{ppm}$ tin and several hundred ppm cesium.

\section{LEAD ISOTOPES}

The U-Pb isotopic compositions of two fractions of zircon separated from a sample of the Fawwarah alkalifeldspar granite indicate that the granite, which is the youngest component of the Silsilah ring complex as indicated by field relations, is $587 \pm 8 \mathrm{Ma}$ old (table 8 , fig. 30). This age is in good agreement with those 


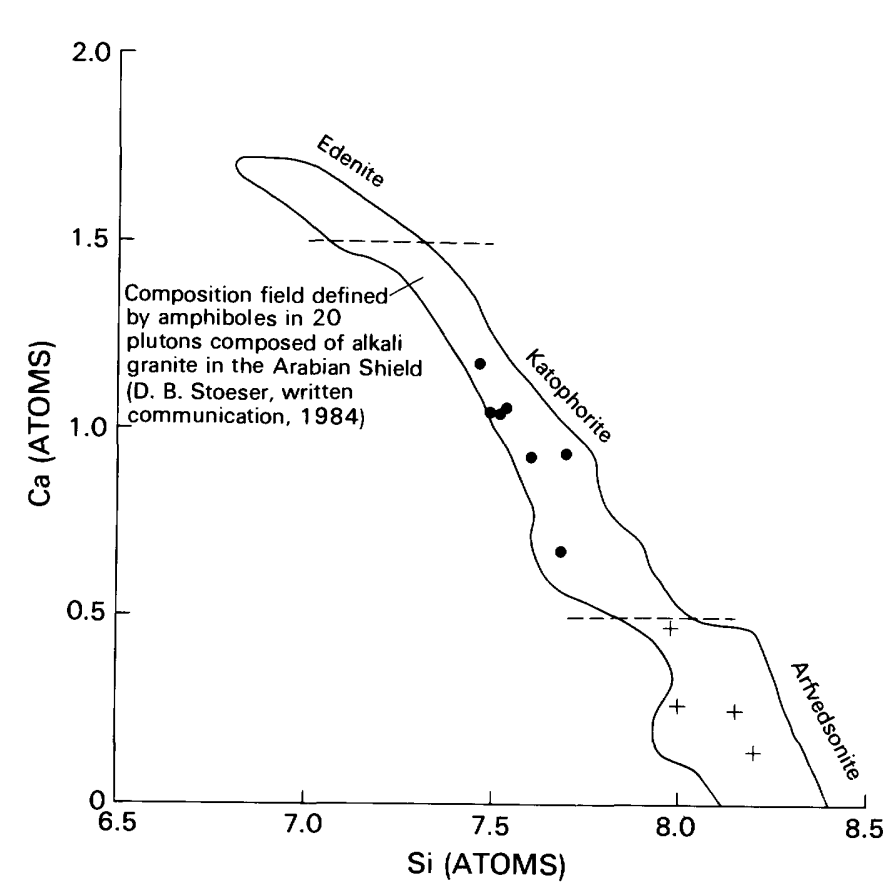

FIgure 29. Plot showing the composition of sodium-bearing amphiboles from the Silsilah ring complex in terms of atoms of calcium versus atoms of silicon in structural formulas; data for amphibole grains from the Silsilah alkali granite shown as solid dots and for amphiboles from the comendite as plusses. Composition field, from ferroedenite to arfvedsonite defined by D. B. Stoeser (written commun., 1984) using analyses for sodium-bearing amphiboles in 20 alkali granite plutons of the Arabian Shield.

determined for other postorogenic plutons of the northeastern Arabian Shield (Stuckless and others, 1984).
The isotopic lead compositions (table 8, fig. 31) of two samples of pure potassium feldspar, from the Silsilah alkali granite and from the Fawwarah alkali-feldspar granite, are identical within the limits of analytical uncertainty. The ratios are unlike those for other samples from the Arabian Shield in that the ${ }^{207} \mathrm{~Pb} /{ }^{204} \mathrm{~Pb}$ and ${ }^{208} \mathrm{~Pb} /{ }^{204} \mathrm{~Pb}$ ratios are low relative to their ${ }^{206} \mathrm{~Pb} /{ }^{204} \mathrm{~Pb}$ ratios. The nonradiogenic character of lead from these two samples is unlike either type I lead-having an oceanic crustal affinity-or type II lead-having an evolved continental crustal affinityas defined by Stacey and others (1980) (fig. 31), although it is more like type I. Relative to average mantle and orogene lead compositions, lead in the samples from the Silsilah ring complex is ${ }^{208} \mathrm{~Pb}$ (thorium lead) depleted and, in terms of ${ }^{207} \mathrm{~Pb}$ (uranium lead), it is intermediate, although more like that characteristic of the mantle. In any case, the lead isotopic composition of these samples indicates that genesis of the ring-complex components did not involve a component of continental material more than $100 \mathrm{Ma}$ older than the complex itself. This observation is in good agreement with the findings of Stuckless and others (1984) for other postorogenic plutons in the northeast Shield.

A linear array is formed by the lead isotopic data for samples from the eastern Arabian Shield. These include gabbro from the Urd ophiolite complex, rocks east of the Al Amar fault, and the Abt intrusive rocks (Stacey and Stoeser, 1983). These compositions have been suggested (D. B. Stoeser, oral commun., 1984) to represent a mixing line between mantle compositions, indicated by the Urd sample and material whose isotopic

TABLE 8.-Uranium, thorium, and lead and uranium isotopic data for mineral separates from samples of the Silsilah ring complex

Potassium Feldspar

\begin{tabular}{lccccc} 
Sample & \multicolumn{3}{c}{ Unit } & & \multicolumn{3}{c}{ Atomic ratios } \\
\cline { 3 - 6 } & & & $\frac{206 \mathrm{~Pb}}{204 \mathrm{~Pb}}$ & $\frac{207 \mathrm{~Pb}}{204 \mathrm{~Pb}}$ & $\frac{208 \mathrm{~Pb}}{204 \mathrm{~Pb}}$ \\
\hline 181964 & Fawwarah alkali-feldspar granite & 17.932 & 15.542 & 37.561 \\
181947 & Silsilah alkali granite & 17.931 & 15.526 & 37.487 \\
\hline
\end{tabular}

Zircon

\begin{tabular}{|c|c|c|c|c|c|c|c|c|c|c|}
\hline \multirow[t]{2}{*}{ Sample } & \multirow[t]{2}{*}{ Size fraction } & \multirow[t]{2}{*}{$\mathrm{U}$} & \multirow[t]{2}{*}{ Th } & \multicolumn{3}{|c|}{ Atomic ratios } & \multicolumn{3}{|c|}{ Ages (Ma) } & \multirow{2}{*}{$\begin{array}{l}\text { Isochron } \\
\text { mode } 1 \\
\text { age } \mathrm{Ma}\end{array}$} \\
\hline & & & & $\frac{206 \mathrm{~Pb}}{238 \mathrm{U}}$ & $\frac{207 \mathrm{~Pb}}{235 \mathrm{U}}$ & $\frac{207 \mathrm{~Pb}}{206 \mathrm{~Pb}}$ & $\frac{208 \mathrm{~Pb}}{238 \mathrm{U}}$ & $\frac{207 \mathrm{~Pb}}{235 \mathrm{U}}$ & $\frac{207 \mathrm{~Pb}}{206 \mathrm{~Pb}}$ & \\
\hline 181964 & \multirow{2}{*}{$\begin{array}{l}-250 \text { mesh, } \\
\text { nonmagnetic } \\
+150 \text { mesh, } \\
\text { magnetic }\end{array}$} & 1715 & 110 & 0.0582 & 0.4742 & 0.05911 & 365 & 394 & 571 & \multirow{2}{*}{$587 \pm 8$} \\
\hline 181964 & & 389 & 35 & 0.0803 & 0.6581 & 0.05941 & 498 & 513 & 581 & \\
\hline
\end{tabular}




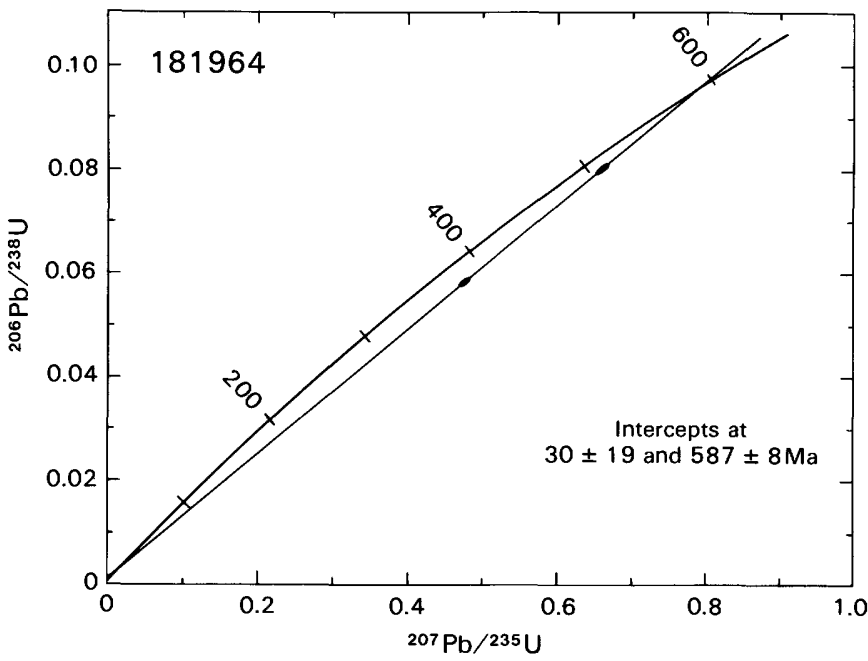

FIGURE 30. Concordia diagram of isotopic data for zircon from the Fawwarah alkali-feldspar granite. Data for two fractions of zircon from sample 181964 are plotted. Intercepts with concordia and their uncertainties are calculated from Ludwig (1980).

composition would plot along the extension of the linear array. The lead isotopic composition of the samples from the Silsilah ring complex plots along this extension and may depict the lead isotopic composition of the protolith with which Urd lead isotopic compositions are mixing to produce the linear array.

\section{MINERALIZED ROGKS}

\section{METHODS}

A 1:2000 scale geologic map of the two intensely mineralized greisens located in the southwest part of the ring complex was prepared using standard plane table and alidade techniques (plate 3). After the mapping was completed, a series of sample lines was laid out to provide locations for representative, evenly spaced samples across both greisen hills (figs. 32 and 33). The sample lines are approximately perpendicular to the long axis of each hill. Samples were collected in 10 - $\mathrm{m}$ intervals; several intervals less than $10 \mathrm{~m}$ long were made where outcrops are absent. Within each interval, approximately $10 \mathrm{~kg}$ of rock were collected on and near the surveyed line, an effort being made to collect a fragment of outcropping rock every $10-20 \mathrm{~cm}$ within each interval. This mode of sample collection is subjective, is susceptible to bias in sample collection, and may yield samples not representative of the rock exposed in the interval. No effort was made to evaluate sampling bias by replicate sampling, but the method was probably adequate for the present study. The

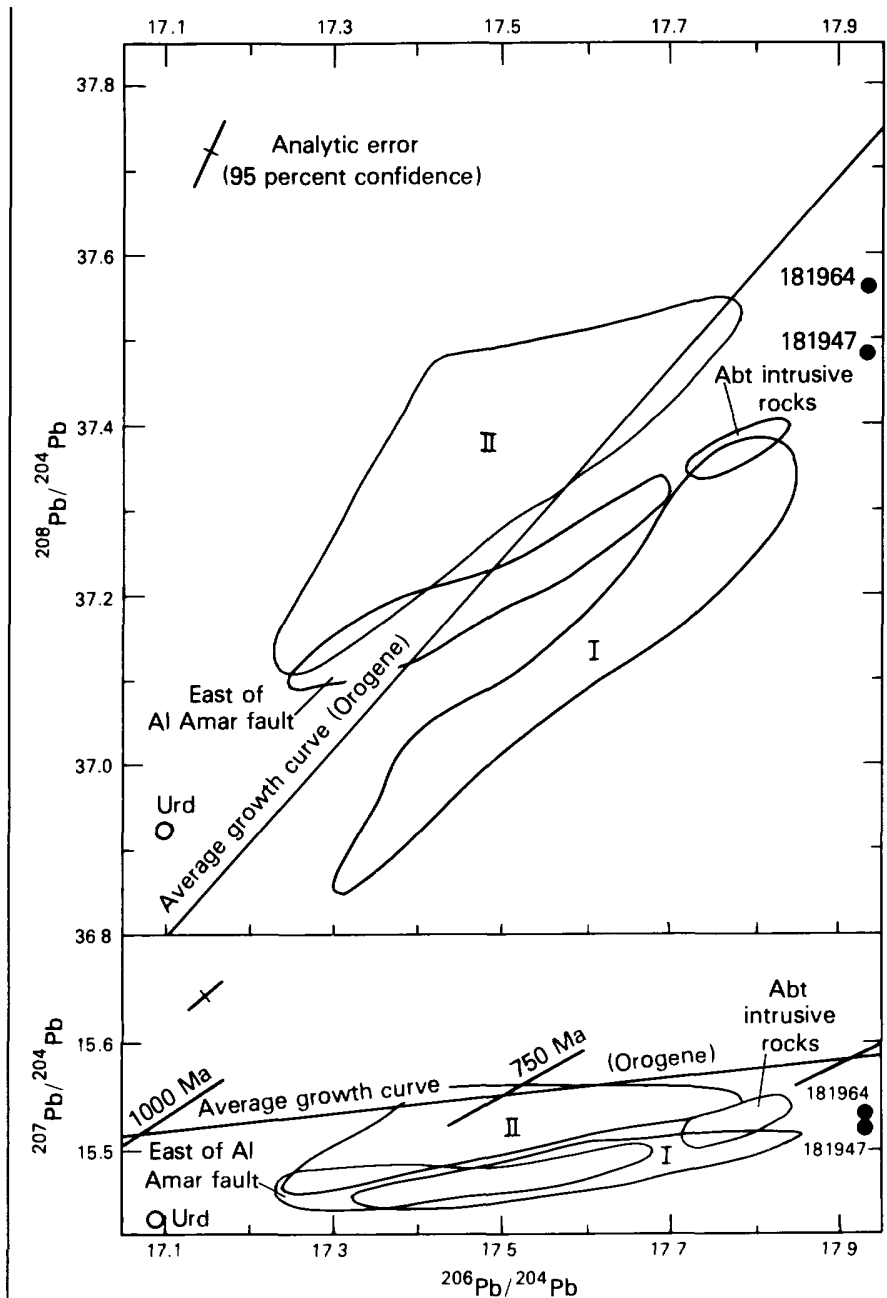

FiguRE 31. Graphs showing common lead isotope data for two samples from the Silsilah ring complex. Sample 181947 is potassium feldspar from the Silsilah alkali granite and sample 181964 is potassium feldspar from the Fawwarah alkali-feldspar granite. Data are listed in table 8. Average growth curves are from Stacey and Kramers (1975). Group I and group II galena fields, Urd, east of Al Amar field, and Abt intrusive field are from Stacey and others (1980).

results probably provide a reasonable estimate of the overall grade of the deposit and helped identify largescale zoning that exists.

Small, isolated greisens and quartz veins in the Silsilah alkali granite were also sampled. Sampling of these was less systematic and at a much lower density than that in the area of plate 3. Samples of greisen consisted of $2-3 \mathrm{~kg}$ of rock chips collected and composited from outcrops within several meters of the sample site. Samples of the quartz veins consisted of $2-3 \mathrm{~kg}$ of quartz selected based on a mineralized appearance; each sample consisted of chips collected and composited from along 1-10 $\mathrm{m}$ of vein strike length. 

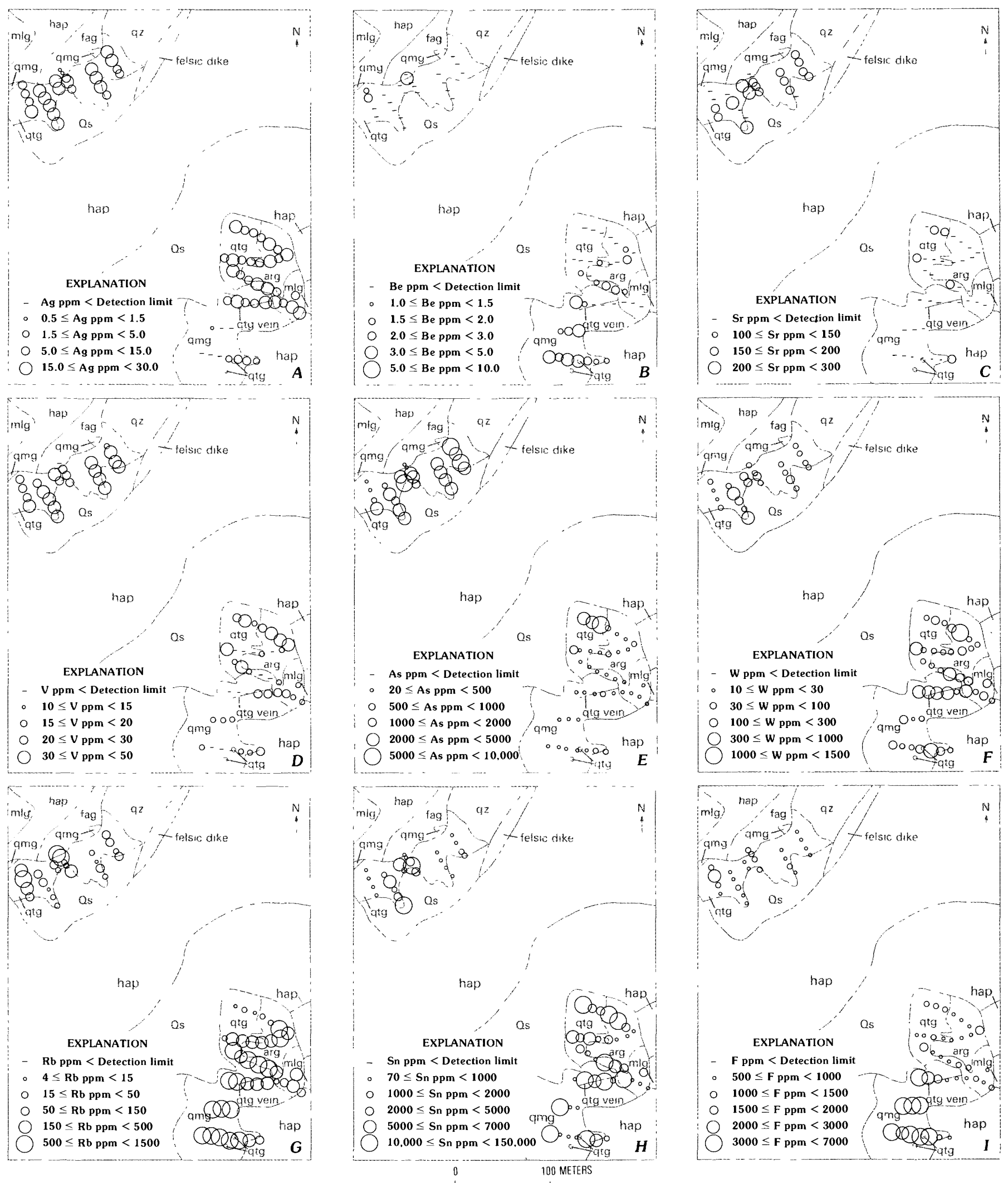

FIGURE 32. Maps showing the distribution of single elements in samples of the intensely mineralized greisens. $A$, Silver; $B$, Beryllium; $C$, Strontium; $D$, Vanadium; $E$, Arsenic; $F$, Tungsten; $G$, Rubidium; $H$, Tin; $I$, Fluorine. 

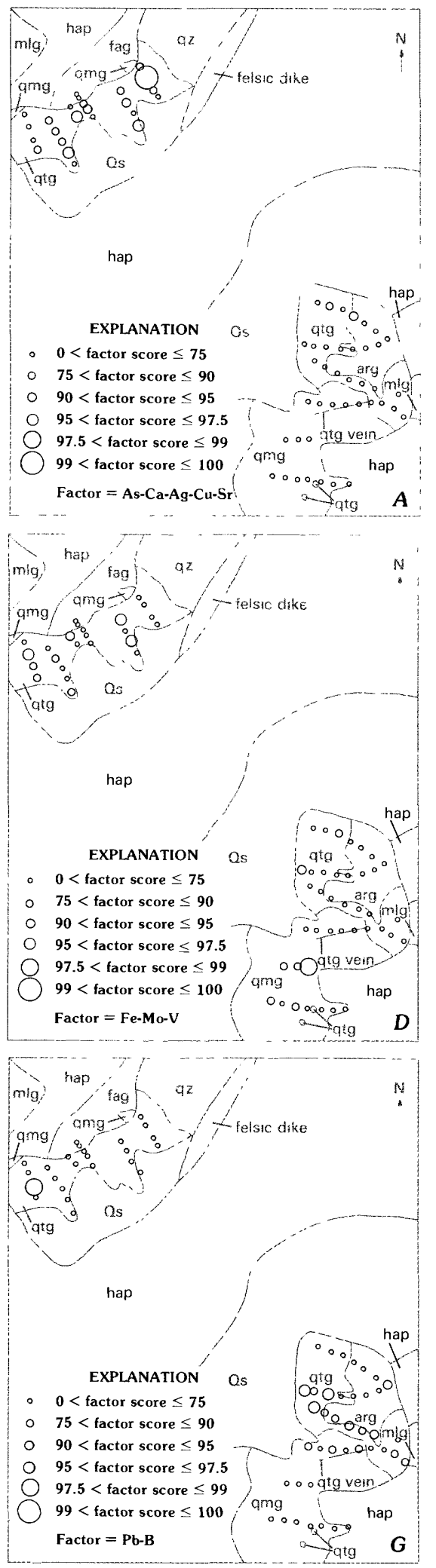
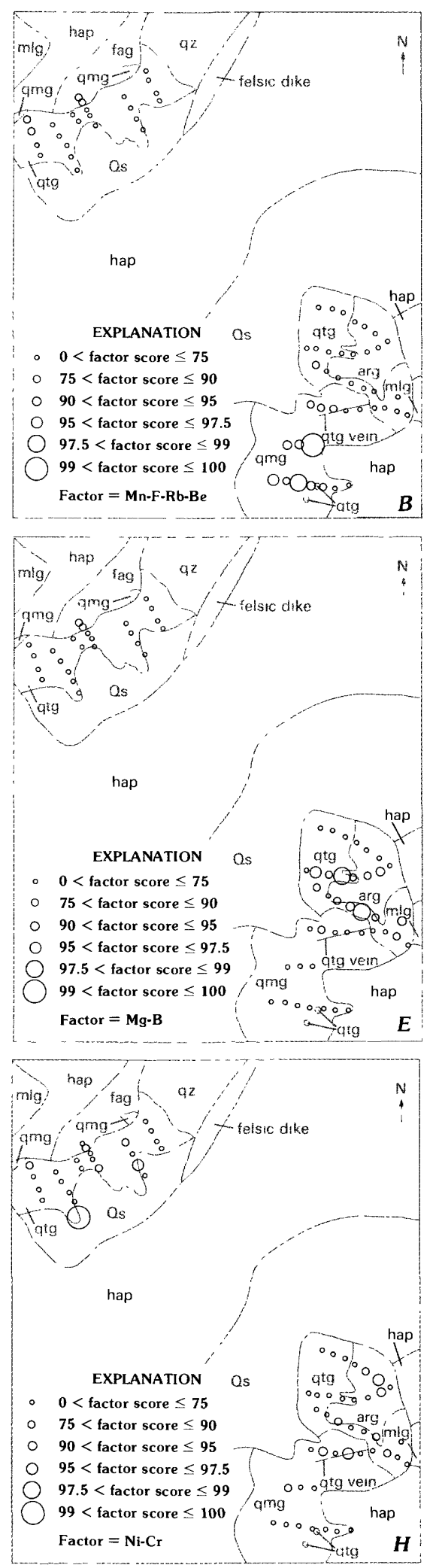
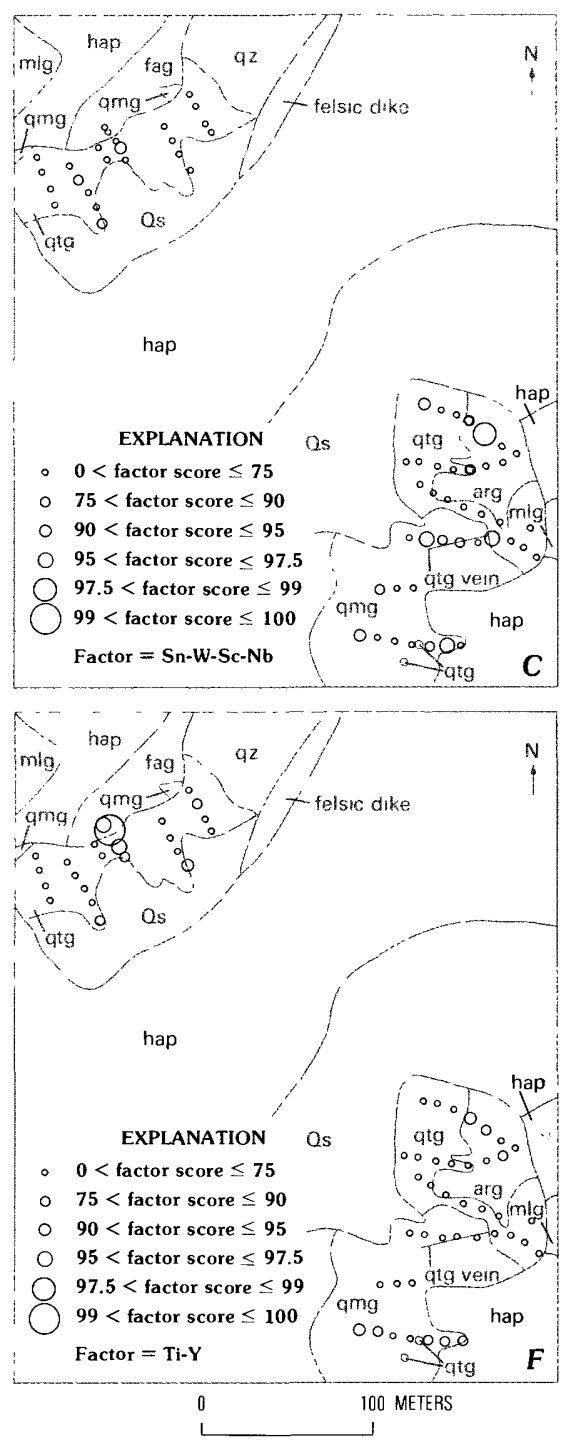

EXPLANATION

Qs Surficial deposits

qtg Complete greisen

qmg Incomplete greisen

arg Argillically altered granite

qz Pegmatite quartz

fag Fawwarah alkali-feldspar granite

hap Hadhir aplite

mlg Maraghan lithic graywache

Figure 33. Maps showing factor scores for samples of the intensely mineralized greisens. $A$, Factor 1 (As, Ca, Ag, Cu, Sr); $B, \mathrm{Factor} 1$ antithesis (Mn, F, Rb, Be); $C$, Factor 2 (Sn, W, Sc, Nb); $D$, Factor $3(\mathrm{Fe}, \mathrm{Mo}, \mathrm{V}) ; E$, Factor 3 antithesis (Mg, B); $F, \mathrm{Factor} 4(\mathrm{Ti}, \mathrm{Y}) ; G$, Factor 4 antithesis (Pb, B); H, Factor $5(\mathrm{Ni}, \mathrm{Cr})$. 


\section{RESULTS FOR INTENSELY MINERALIZED GREISENS}

A basic measure of the elemental concentrations in the greisens was obtained through calculation of the mean and standard deviation of concentration for each element determined in the set of 68 samples collected across the two intensely mineralized greisens (table 9). The mean concentrations of $\mathrm{Ag}, \mathrm{B}, \mathrm{Bi}, \mathrm{Mo}, \mathrm{Nb}, \mathrm{Pb}, \mathrm{Zn}$, As, Sn, W, and F, which are present in anomalous to highly anomalous concentrations relative to the lowcalcium granite of Turekian and Wedepohl (1961), are of particular interest. Most of these elements are not present in sufficiently high concentrations to be of economic interest, but they serve as pathfinders to tin and associated deposits (Tischendorf, 1977) and also reflect the hydrothermal process that caused greisenization.

The elements $\mathrm{Sn}, \mathrm{W}, \mathrm{Ag}, \mathrm{As}, \mathrm{Bi}, \mathrm{Pb}, \mathrm{Cu}, \mathrm{Rb}$, and $\mathrm{Zn}$ are all present in highly anomalous concentrations and are characterized by wide ranges of abundances, as indicated by the standard deviations of their concentrations. The levels of concentration, however, suggest that

TABLE 9.-Elemental means and standard deviations for 68 samples collected from the two intensely mineralized greisens in the southwest part of the Silsilah ring complex.

[Samples composited from rock chips collected in $10 \mathrm{~m}$ intervals. Determinations by the DGMR/USGS chemical laboratory, Jiddah, using semiquantitative spectrographic techniques, unless otherwise indicated. All values in parts per million, except iron, magnesium, calcium, and titanium which are in percent]

\begin{tabular}{|c|c|c|c|c|}
\hline Element & $\begin{array}{l}\text { Detection } \\
\text { limit }\end{array}$ & Mean & $\begin{array}{l}\text { Standard } \\
\text { deviation }\end{array}$ & $\begin{array}{l}\text { Number of un- } \\
\text { qualified data }\end{array}$ \\
\hline $\mathrm{Fe}$ & 0.05 & 2.76 & 1.15 & 68 \\
\hline $\mathrm{Mg}$ & .02 & 0.04 & 0.03 & 68 \\
\hline $\mathrm{Ca}$ & .05 & .84 & .61 & 68 \\
\hline $\mathrm{T} i$ & .002 & .01 & .03 & 43 \\
\hline Mn & 10 & 429 & 524 & 68 \\
\hline $\mathrm{Ag}$ & .5 & 9 & 5 & 63 \\
\hline B & 10 & 13 & 4 & 22 \\
\hline $\mathrm{Ba}$ & 20 & 61 & 33 & 68 \\
\hline $\mathrm{Be}$ & 1 & 2 & 2 & 24 \\
\hline $\mathrm{Bi}$ & 10 & 53 & 54 & 66 \\
\hline $\mathrm{Cr}$ & 10 & 296 & 93 & 68 \\
\hline $\mathrm{Cu}$ & 5 & 106 & 68 & 68 \\
\hline Mo & 5 & 12 & 8 & 57 \\
\hline $\mathrm{Nb}$ & 20 & 64 & 19 & 68 \\
\hline $\mathrm{Ni}$ & 5 & 7 & 2 & 59 \\
\hline $\mathrm{Pb}$ & 10 & 661 & 477 & 68 \\
\hline $\mathrm{Sc}$ & 5 & 6 & 2 & 7 \\
\hline $\mathrm{Sr}$ & 100 & 130 & 42 & 23 \\
\hline $\mathrm{V}$ & 10 & 16 & 5 & 54 \\
\hline $\mathrm{Y}$ & 10 & 12 & 3 & 22 \\
\hline $\mathrm{Zn}$ & 200 & 324 & 137 & 21 \\
\hline $\mathrm{Zr}$ & 10 & 83 & 20 & 68 \\
\hline $\mathrm{As}^{\mathrm{a}}$ & 2 & 1367 & 1913 & 64 \\
\hline $\mathrm{Sn}^{\mathrm{a}}$ & 4 & 9527 & 21347 & 64 \\
\hline $\mathrm{w}^{\mathrm{a}}$ & $\begin{array}{r}4 \\
10\end{array}$ & 175 & 241 & 64 \\
\hline $\mathrm{Rb}^{\mathrm{a}}$ & 2 & 361 & 393 & 64 \\
\hline $\mathrm{F}^{\mathrm{b}}$ & 50 & 1489 & 1328 & 64 \\
\hline
\end{tabular}

a Determined by X-ray fluorescence, COMLABS, Australia.

b Determined by selected ion electrode, COMLABS, Australia. only tin occurs at potentially economic grades. W and $\mathrm{Ag}$ may be viable as by-products. Other elements, including $\mathrm{Ba}, \mathrm{Sr}, \mathrm{Ni}$, and $\mathrm{V}$, are present in anomalously low abundances.

The variation of individual elemental abundances was examined using a series of single-element concentration maps to determine whether the geochemistry of the greisens was systematically zoned. These maps were also used to determine whether zonation could be correlated with surface geology. The concentration variation of the elements $\mathrm{Fe}, \mathrm{Ca}, \mathrm{Ti}, \mathrm{Mn}, \mathrm{B}, \mathrm{Ba}, \mathrm{Bi}, \mathrm{Cr}, \mathrm{Cu}$, $\mathrm{Mo}, \mathrm{Nb}, \mathrm{Ni} \mathrm{Pb}, \mathrm{Sc}, \mathrm{Y}, \mathrm{Zn}$, and $\mathrm{Zr}$ in the samples of the two intensely minerahzed greisens does not display systematic spatial variation, so their univariant distributions are not further considered. The elements Ag, $\mathrm{Be}, \mathrm{Sr}, \mathrm{V}, \mathrm{As}, \mathrm{W}, \mathrm{Rb}, \mathrm{F}$, and Sn have broad concentration ranges and their abundances (fig. 32) are characterized by systematic spatial variation that is consistent with surface geology in most cases.

The distribution of silver is fairly homogeneous except that it is distinctly depleted in parts of the southern greisen composed of incomplete greisen (fig. $32 A$ ). The physicochemical conditions which resulted in formation of the quartz-zinnwaldite assemblage in the incomplete greisen evidently did not favor concentration of silver.

The beryllium content of samples from the southern greisen is slightly higher than that of samples from the northern greisen (fig. 32B). Beryllium concentrations are particularly high in the southern part of the southern greisen where incomplete greisen crops out. Beryllium may substitute for manganese, a major constituent of zinnwaldite, which is a major constituent of the incomplete greisen. Thus, beryllium may be a good pathfinder to incomplete greisen.

The strontium content of the northern greisen is distinctly higher than that characteristic of the southern greisen (fig. $32 C$ ). This observation exemplifies the geochemical distinction between the two intensely mineralized greisens. Strontium is preferentially partitioned into the solid phase because of its compatible behavior (Hanson, 1978) and is, therefore, less abundant in subsequently solidified materials. Thus, the higher strontium content of the northern greisen suggests that it may represent a less evolved stage in the development of the hydrothermal system. Hydrothermal alteration responsible for the northern greisen may have removed strontium from greisenizing fluids prior to evolution of the fluids responsible for development of the southern greisen.

The vanadium content of samples from the northern greisen is less variable and slightly higher than that characteristic of the southern greisen (fig. 32D). Vanadium concentrations are anomalously low in 
samples of incomplete greisen or argillically altered granite.

The distribution of arsenic displays the strongest zonation of any element determined (fig. 32E). The arsenic content of the northern greisen is about five times that of the southern greisen and is highly anomalous relative to the arsenic content of most rocks (Turekian and Wedepohl, 1961). Three samples from the northwest corner of the southern greisen also contain highly anomalous concentrations of arsenic. The geochemical behavior of arsenic and sulfur are similar, and arsenic is commonly a major constituent of sulfide mineralized rock. The dissimilarity of arsenic content between the two greisens suggests that either the northern greisen experienced a sulfide-dominated hydrothermal event not experienced by the southern greisen or both greisens experienced this event and that evidence of this sulfide event was subsequently overprinted by a hydrothermal event which affected only the southern greisen. Poorly developed distribution patterns for other chalcophile elements suggest that they are also more abundant in the northern greisen. The variation of arsenic content between samples of the two greisens may result from geochemical zonation of one hydrothermal system or may represent the effects of superposed hydrothermal events.

The tungsten content of the southern greisen is slightly higher than that of the northern greisen (fig. $32 F$ ), but no zonation of tungsten is apparent. Tungsten, like niobium, substitutes for tin in cassiterite (Dudykina, 1959). The low tungsten content of the greisens suggests that tungsten is a constituent of cassiterite in this system and does not form tungsten minerals to any significant extent. Possibly, however, the distribution of tungsten reflects the sporadic distribution of very small quantities of tungsten minerals such as wolframite and wolframoixiolite, which have been identified in samples of the greisens. The tungsten content of the greisens is anomalous but is not indicative of a significant tungsten resource.

The rubidium content of the southern greisen is higher than that of the northern greisen, where rubidium is more erratically distributed (fig. $32 G$ ). Rubidium acts incompatibly (Hanson, 1978) and, as is observed in this case, its distribution is antithetic to that of strontium. The distribution of rubidium substantiates the hypothesis that the physicochemical conditions responsible for genesis of the two greisens were dissimilar. The rubidium content of samples from the south part of the southern greisen, where the mineral assemblage quartz-zinnwaldite prevails, is distinctly higher than it is elsewhere. Given the mineralogy of the greisens, the geochemical affinities of rubidium, and high rubidium contents observed in zinnwaldite (Deer and others, 1962), the rubidium can be inferred to reside in zinnwaldite. Thus, high rubidium contents indicate samples that contain abundant zinnwaldite and, because the distributions of rubidium and tin are generally antithetic (figs. $32 \mathrm{G}$ and $32 \mathrm{H}$ ), areas characterized by high rubidium contents are less favorable for highgrade deposits of tin.

The fluorine contents are low for samples of greisen (fig. $32 I$ ) but are consistent with their low fluorite content. With the exception of samples from the south half of the southern greisen, the fluorine contents of the two greisens are similar; samples from the southern area contain distinctly more fluorine than samples from other areas. The higher fluorine content of these samples is attributable to the abundance of zinnwaldite, which contains 4-8 percent fluorine (Deer and others, 1962 ) in the incomplete greisen that underlies the south part of the southern greisen. The abundance of topaz, the other fluorine-bearing mineral in the greisens, does not affect the fluorine distribution because its distribution is approximately constant in the greisens.

The highly anomalous tin content of both greisens (fig. $32 \mathrm{H}$ ), attributable to the presence of disseminated cassiterite, suggests that economic deposits of tin could occur within the Silsilah greisens. Samples of the greisens contain between $75 \mathrm{ppm}$ and $121,000 \mathrm{ppm}$ tin, although few contain less than $1000 \mathrm{ppm}$. The average tin content of samples from the southern greisen is $10,000 \mathrm{ppm}$ tin whereas that for samples from the northern greisen is $5,000 \mathrm{ppm}$ (du Bray, 1983c), and the distribution of tin within the two greisens displays some systematic variation. The central part of the northern greisen contains distinctly more tin than other parts of this greisen, but tin's variation does not correlate with lithologic variation within the greisen (fig. $32 \mathrm{H}$ ). A correlation exists between lithology and tin content in the southern greisen. Areas underlain by complete greisen generally contain more tin than areas underlain by incomplete greisen or argillically altered alkali-feldspar granite (fig. $32 \mathrm{H}$ ).

A correlation coefficient matrix (du Bray and others, 1984) was computed using the geochemical data for samples from the two intensely mineralized greisens. Entries in the matrix indicate the degree to which variance between elements of the sample set is correlated. Correlation coefficients greater than 0.6 were arbitrarily designated as being significant; element pairs that meet this criterion and their correlation coefficients are listed in table 10. Scandium, titanium, chromium, and vanadium have the same valence and similar ionic radii. The correlations observed between scandium and the other three elements are, therefore, 
TABLE 10.-Element pairs with correlation coefficients $\geqslant 0.60$ in 68 samples from intensely mineralized greisens

[+ and - indicate positive and negative correlations, respectively]

\begin{tabular}{ll}
\hline Elements & $\begin{array}{l}\text { Correlation } \\
\text { coefficient }\end{array}$ \\
\hline
\end{tabular}

$\begin{array}{ll}\mathrm{Ti}+\mathrm{Mg} & 0.647\end{array}$

$\mathrm{Ti}+\mathrm{Be} \quad .712$

$\mathrm{Pb}+\mathrm{Ag} \quad .645$

$\mathrm{Sc}+\mathrm{Ti} \quad .626$

$\mathrm{Sc}+\mathrm{Cr} \quad .719$

$\mathrm{Sc}+\mathrm{V} \quad .757$

$\mathrm{Zn}+$ Mo $\quad .618$

$\mathrm{Zn}+\mathrm{Ni} \quad .609$

$\mathrm{Zn}+\mathrm{Y} \quad .739$

$\mathrm{Sn}+\mathrm{Nb} \quad .621$

$\mathrm{Sn}+\mathrm{Sc} \quad .614$

$\mathrm{Sn}+\mathrm{W} \quad .600$

$\mathrm{W}+\mathrm{Sc} \quad .761$

$\mathrm{F}+\mathrm{Mn} \quad .952$

$\mathrm{Rb}+\mathrm{Mn} \quad .834$

$\mathrm{Rb}+\mathrm{F} \quad .763$

$\mathrm{Rb}+\mathrm{Be} \quad .792$

$\begin{array}{ll}\mathrm{V}-\mathrm{Ba} & .605\end{array}$

a consequence of their substitution for scandium in crystal lattices. Similarly, zinc and nickel have the same valence and similar ionic radii and freely substitute for one another. The correlation between lead and silver is probably a consequence of the presence of silver in galena, probably as impurities or as acanthite (Deer and others, 1966). The causes for other correlations indicated in table 10 are not known.

The correlation matrix also facilitates qualitative identification groups of elements that display positively correlated covariation. Elemental covariation of this type is a consequence of coherent geochemical behavior by members of the association. The two identified associations are:

$$
\begin{array}{r}
M n+F+R b, \\
S n+S c+W+N b .
\end{array}
$$

Zinnwaldite is the principal mineralogic residence of $\mathrm{Mn}, \mathrm{F}$, and Rb in the greisen samples. The close association of these elements in the greisen samples suggests that their concentrations are mutually controlled by the zinnwaldite content of individual samples. Similarly, Sn, $\mathrm{Sc}, \mathrm{W}$, and $\mathrm{Nb}$ are concentrated in cassiterite and their abundances covary as a consequence of each sample's cassiterite content.
A more rigorous treatment of elemental associations was conducted using $R$-mode factor analysis. The data were transformed to logarithms and then analyzed by the $R$-mode, multivariate factor analysis procedure (Miesch, 1980) which is based on the correlation coefficients between all the variables. Correlation coefficients express the association of one element to another, but factor analysis considers all correlations simultaneously and identifies several common associations of elements that best characterize the data. The procedure also provides a quantitative measure of the importance of each element in a given association. Each of these associations can in many cases be related to a specific rock type or specific locality where the controlling features of the association might be inferred (Allen and others, 1983).

The use of factor analysis, in this case, helped clarify and add to the associations identified by the correlation matrix. A five-factor model, the simplest model that can be reasonably explained in geologic terms, was selected. Several of the factors identified include an tithetic associations. That is, one group of strongly associated elements displays strong negative correlation with a second group of strongly associated elements. The factors and their components are listed in table 11.

High values for factor 1 are concentrated in the northern greisen (fig. $33 A$ ) whereas high values for the antithetic part of factor 1 occur in the southern part of the southern greisen (fig. $33 B$ ). The As-Ca-Ag-Cu-Sr component of factor 1 emphasizes the profound geochemical difference between the two greisens. This elemental association suggests that the factor includes both chalcophile/sulfide and feldspar components that are not present in the southern greisen. The elements associated in the antithetic part of factor 1 are those whose distribution is controlled by the distribution of zinnwaldite; high values for this factor are coincident with outcrops of incomplete greisen.

The distribution of high values for factor 2 , as previously indicated by univariant statistics, is controlled by the distribution of cassiterite (fig. 33C).

The elemental association depicted by factor 3 is enigmatic but again denotes the geochemical dissimilarity that exists between the two intensely mineralized greisens (fig. 33D). The northern greisen contains more high values for this factor than the northern part of the southern greisen; the distribution of high values for this factor suggests that the southern part of the southern greisen is more similar to the northern greisen than to the southern greisen. High values for the antithetic part of factor 3, the Mg-B association, show good correlation with outcrops of argillically altered alkali-feldspar 
TABLE 11.-Components of the factors in the five-factor model for samples of the two strongly mineralized greisens

\begin{tabular}{cll} 
Factor & Elements Associated & Antithetic Element Association \\
\hline 1 & $\mathrm{As}, \mathrm{Ca}, \mathrm{Ag}, \mathrm{Cu}, \mathrm{Sr}$ & $\mathrm{Mn}, \mathrm{F}, \mathrm{Rb}, \mathrm{Be}$ \\
2 & $\mathrm{Sn}, \mathrm{W}, \mathrm{Sc}, \mathrm{Nb}$ & $\mathrm{Mg}, \mathrm{B}$ \\
3 & $\mathrm{Fe}, \mathrm{Mo}, \mathrm{V}$ & $\mathrm{Pb}, \mathrm{B}$ \\
4 & $\mathrm{Ti}, \mathrm{Y}$ & \\
5 & $\mathrm{Ni}, \mathrm{Cr}$ & \\
\hline
\end{tabular}

granite (fig. $33 E$ ) and, thus, could be utilized to identify additional, similarly altered rock elsewhere in this geologic setting.

The distribution of high values for factor 4 is restricted to small, isolated areas within the two greisens and probably represents the limited occurrence of an as yet unrecognized oxide phase (fig. $33 F$ ). Titanium is the element that controls this factor which suggests that a titanium mineral such as rutile or ilmenite controls the factor. Rutile has been identified in several polished thin sections of complete greisen (Mike Allen, written commun., 1983). The distribution of high values for the antithetic part of this factor mimics that of factor 3's antithetic component (fig. 33G) and suggests that the factors that governed argillic alteration are also responsible for the antithetic component of factor 4.

The distribution of high values for factor 5 is erratic and unrelated to geology or mineralogy (fig. $33 H$ ). These characteristics and the components of the association suggest that this factor is attributable to a random process such as contamination in the analytical laboratory. The concentrations of nickel and chromium in samples with high values for this factor are much higher than would be expected in samples from a greisen environment. The samples may have been contaminated by the random addition of steel chips from the jaw crushers used to crush the samples.

\section{RESULTS FOR OTHER MINERALIZED AREAS}

Mineralized rock in several other small areas in the southwest part of the Silsilah ring complex, which are indicated by a series of circled numbers ( 1 to 5$)$ on figure 34 , is generally similar to rock encountered in the two intensely mineralized greisens. However, most of these areas include mineralized quartz veins, and one of the occurrences consists entirely of mineralized quartz veins. The weakly mineralized rock in these areas was examined and sampled in a reconnaissance fashion.

The geochemistry of nine composited grab samples collected from area 1 (table 12), an area of greisenized rock located $500 \mathrm{~m}$ west-northwest of the large central cupola of Fawwarah alkali-feldspar granite, indicates that the area is weakly tin mineralized. Several greisens located immediately south of this area are lithologically similar but were not sampled. The area is underlain by cassiterite-bearing complete greisen that is barely emergent through erosional windows in the overlying Maraghan lithic graywacke (plate 1). The geochemical signature of the rock in this area is similar to that of the two intensely mineralized greisens, although the geochemistry of these greisens is not as anomalous as that of the intensely mineralized greisens.

In area 2, which is about $2 \mathrm{~km}$ east-northeast of area 1 , the northernmost outcrop of the Fawwarah alkalifeldspar granite is weakly mineralized. The alkalifeldspar granite is cut by a series of narrow quartz veins that trend $\mathrm{N} .70^{\circ} \mathrm{W}$. Most of these veins are $1-2 \mathrm{~cm}$ wide and have greisenized borders $0.5-3 \mathrm{~cm}$ wide. Six samples of the most intensely mineralized quartz veins indicate that these quartz veins contain weakly anomalous concentrations of many of the elements in table 12.

In area 3, a series of mineralized quartz veins, similar to those in area 2, cut the large central cupola of the Fawwarah alkali-feldspar granite. These veins trend $\mathrm{N}$. $70^{\circ} \mathrm{W}$. and have greisenized borders like those of veins in area 2 . The veins in area 3 are more variable in width, $1-10 \mathrm{~cm}$ wide, and have wider greisenized borders. Several weak to moderately greisenized pods of the alkali-feldspar granite also crop out in this area. The greisenized rock forms tabular bodies that are approximately parallel to the trend of the quartz veins, and their origin may have been controlled by the same fracture pattern that seems to have localized the quartz veins. Five composited quartz-vein samples contain anomalous concentrations of the elements shown in table 12. The concentrations of $\mathrm{Sn}, \mathrm{W}, \mathrm{Ag}, \mathrm{Bi}, \mathrm{Mo}$, and $\mathrm{Pb}$ are not as highly anomalous as they are in samples from the intensely mineralized greisens, but they indicate that the rock in this area was subjected to a hydrothermal event similar to that responsible for the intensely mineralized greisens.

Area 4 is underlain by a complex composed of weakly mineralized Hadhir aplite, Fawwarah alkali-feldspar granite, and greisen. The textural features of the aplite and granite suggest that a fluid phase was involved in the solidification of these rocks. The geometric relations of these rocks, with the Hadhir aplite above and in contact with the Fawwarah alkali-feldspar granite, is 
TABLE 12.-Geochemical summary for samples collected from other mineralized areas within the southwest part of the Silsilah ring complex

[Area numbers keyed to fig. 34. $\mathrm{N}$ indicates not detected; $\mathrm{L}$ indicates less than detection limit. Uncensored data used for calculation of means. All values in parts per million. Leader indicates no unqualified datal

\begin{tabular}{|c|c|c|c|c|c|c|}
\hline $\begin{array}{l}\text { Area } \\
\text { Numbe }\end{array}$ & er of samples & $\begin{array}{l}1 \\
9\end{array}$ & $\begin{array}{l}2 \\
6\end{array}$ & $\begin{array}{l}3 \\
5\end{array}$ & $\begin{array}{l}4 \\
6\end{array}$ & $\begin{array}{l}5 \\
5\end{array}$ \\
\hline \multirow{2}{*}{ Ag [ } & Range & $N-5$ & $L-5$ & ${ }^{a} L-20$ & ${ }^{a} L-2$ & $L-50$ \\
\hline & Mean & 3 & 3 & 3 & - & 16 \\
\hline \multirow{2}{*}{ As [ } & Range & $a_{34-8550}$ & $a_{190-3550}$ & $a_{155-1650}$ & $18-55$ & $a_{90-2800}$ \\
\hline & Mean & 402 & 424 & 320 & 28 & 386 \\
\hline \multirow{2}{*}{ B [ } & Range & $\mathrm{L}-20$ & $L-30$ & $20-30$ & - & - \\
\hline & Mean & 17 & 17 & 22 & - & - \\
\hline \multirow{2}{*}{$\mathrm{Be}[$} & Range & $3-10$ & $2-7$ & $2-5$ & $5-10$ & - \\
\hline & Me an & 7 & 4 & 4 & 7 & - \\
\hline \multirow{2}{*}{ Bi [ } & Range & $N-50$ & - & $a_{N-50}$ & - & $a_{10-1000}$ \\
\hline & Mean & 33 & - & $\mathrm{N}$ & - & 43 \\
\hline \multirow[b]{2}{*}{ Mo [ } & Range & $4-115$ & $6-20$ & $4-10$ & $a_{10-65}$ & $a_{20-260}$ \\
\hline & Mean & 27 & 10 & 6 & 11 & 30 \\
\hline \multirow{2}{*}{$\mathrm{Nb} \quad[$} & Range & $20-70$ & $20-30$ & $30-50$ & $30-50$ & $a_{L-500}$ \\
\hline & Mean & 43 & 27 & 38 & 40 & - \\
\hline \multirow{2}{*}{$\mathrm{Pb}[$} & Range & $30-300$ & $30-150$ & $a_{20-2000}$ & $50-70$ & $a_{20-20,000}$ \\
\hline & Mean & 113 & 88 & 218 & 58 & 618 \\
\hline \multirow{2}{*}{ Sn [ } & Range & $a_{26-2150}$ & $30-170$ & $145-290$ & $12-210$ & $a_{42-1200}$ \\
\hline & Mean & 110 & 88 & 218 & 66 & 230 \\
\hline \multirow[b]{2}{*}{ W [ } & Range & $20-260$ & $15-210$ & $40-135$ & $10-25$ & $a_{10-189,000}$ \\
\hline & Mean & 103 & 81 & 67 & 17 & 438 \\
\hline \multirow{2}{*}{$\mathrm{F} \quad[$} & Range & $535-2093$ & $292-876$ & $a_{876-2969}$ & $438-2530$ & $292-1509$ \\
\hline & Mean & 1244 & 487 & 1083 & 1567 & 1003 \\
\hline
\end{tabular}

a The high value indicated in the data range is a single, highly anomalous value and was not used in calculating the mean.

similar to that observed elsewhere in the ring complex. The subhorizontal contact between these units is known to be the locus of greisenization within this system. These samples contain slightly higher concentrations of some of these elements relative to other granitoid rocks but do not seem to be mineralized to any great extent.

In area 5 , the Silsilah alkali granite has been intruded by the Fawwarah alkali-feldspar granite and the Hadhir aplite and is cut by a series of nearly vertical quartz veins. This vein set, whose density and moderate degree of mineralization are unique to this part of the Silsilah ring complex, trends N. $40^{\circ} \mathrm{E}$. and can be traced to the top of the Fawwarah alkali-feldspar granite. The alkali granite has been altered by the upward migration of hydrothermal fluid from the alkali-feldspar granite, but 
its textural characteristics were preserved. A genetic relation may exist between the hydrothermal alteration of the alkali granite and the emplacement of the quartz vein set in this area. Approximately five veins per $10 \mathrm{~m}$ of outcrop are encountered along the ridge that strikes eastward through area 5 . The veins are significantly wider at the east end of the area than at the west end. The western veins are $1-5 \mathrm{~cm}$ in width and have very weakly greisenized borders. The eastern veins are $5-30 \mathrm{~cm}$ wide and are enclosed in well-developed greisen envelopes that are 0.5-2 $\mathrm{m}$ wide. Blades of wolframite $2-10 \mathrm{~cm}$ long are especially common in the easternmost veins, but the average tungsten content of these veins is low and its distribution is very erratic. Geochemical data for five veins in this area are summarized in table 12. High values for lead and tin are consistent with the sporadic occurrence of galena and cassiterite in these veins.

Three other, very small, areas in the southwest part of the complex are weakly mineralized and were briefly studied. These areas are not numbered on figure 34 but single sample sites (plate 2) denote the location of two of these three areas.

One-half kilometer west of area 5 (fig. 34), a very small elliptically shaped area of greisenized rock was identified within the Fawwarah alkali-feldspar granite. The greisenized rock seems to follow the trend of the prevailing joint set in this area and is composed of quartz, topaz, and a minor amount of zinnwaldite. A single sample (201092) of this greisen contains $5 \mathrm{ppm} \mathrm{Ag,} 520 \mathrm{ppm}$ As, 20 ppm Bi, 1500 ppm Pb, 1650 ppm Sn, and 690 ppm W. The greisen is similar in geologic setting and petrographic attributes to two small, isolated greisens located about $1 \mathrm{~km}$ to the northwest, also in the alkalifeldspar granite. These pods were not sampled but their geochemistry is probably similar to that of the pod described above.

A small, isolated pod of greisen is located about onehalf kilometer northwest of the intensely mineralized greisens, on the northwest flank of the large white hill

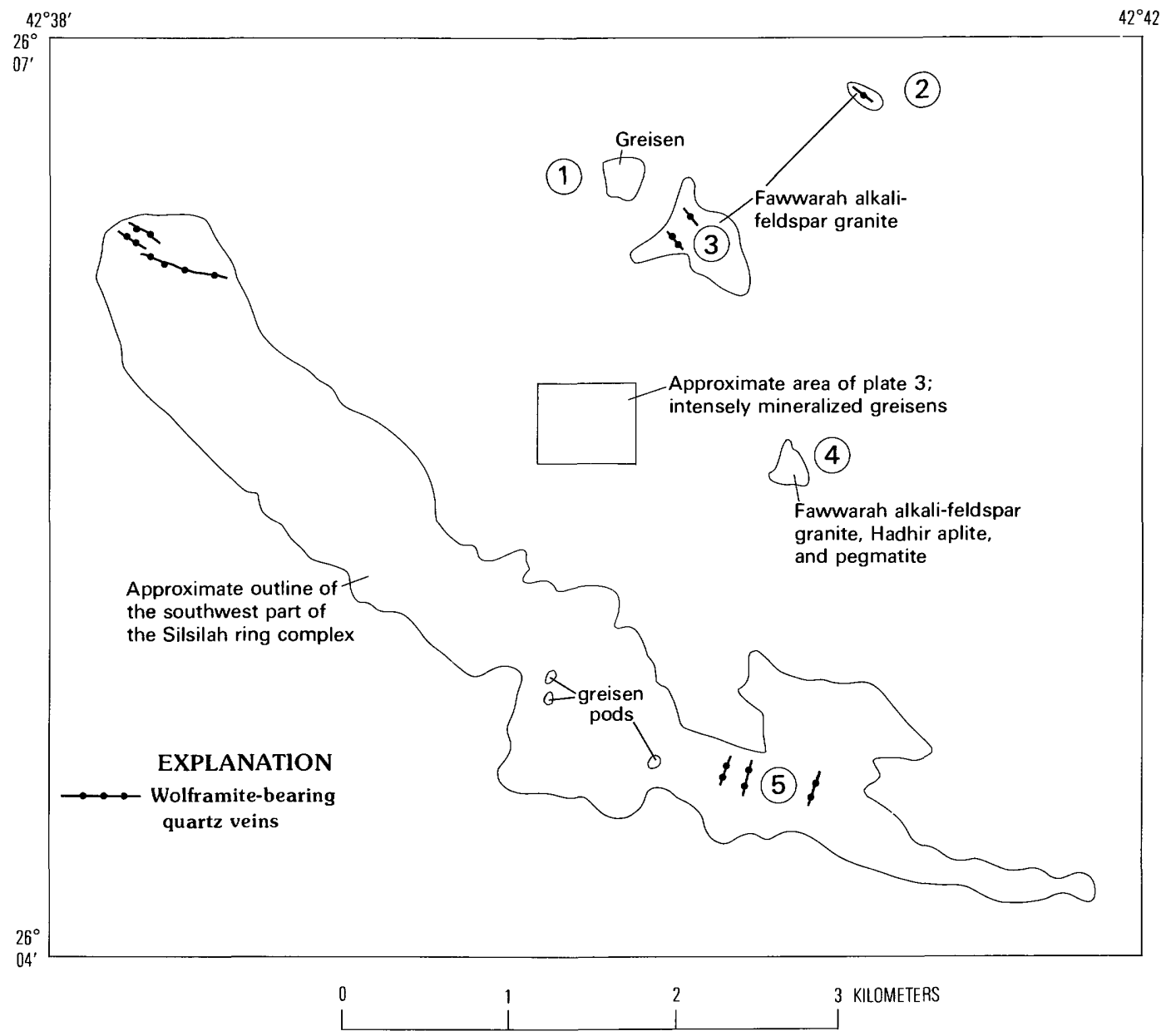

FIGURE 34. Index map showing the location of the intensely mineralized greisens and other mineralized areas. 
underlain by pegmatite (plate 2). A single sample (201098) of this material contains $300 \mathrm{ppm} \mathrm{As,} 100 \mathrm{ppm}$ $\mathrm{Bi}, 200 \mathrm{ppm} \mathrm{Pb}, 550 \mathrm{ppm} \mathrm{Sn}$, and $25 \mathrm{ppm}$ W. The rock is petrographically similar to the quartz-topazzinnwaldite rock that is found peripheral to the two intensely mineralized greisens.

The area near the northwest end of the Fawwarah alkali-feldspar granite is cut by a series of quartz veins that contain variable amounts of wolframite. Samples collected by du Bray (1983c) indicated that the tungsten content of these veins is generally low and very erratic. One vein is traceable across the entire width of the alkali-feldspar granite. The vein attains a maximum width of about $2 \mathrm{~m}$ midway along its strike and thins to a series of anastomosing veins at both ends. The vein is enclosed in a greisenized envelope $0.5-2 \mathrm{~m}$ wide and contains blades of wolframite $2-5 \mathrm{~cm}$ long in the central area. The overall wolframite content of this vein and of the entire vein set in this area seems to be low and does not warrant additional study.

A series of samples of the Maraghan lithic graywacke (samples 181940-181946) was collected radially inward from the point, on the east side of the proto-Fawwarah alkali-feldspar granite's northernmost outcrops along the ring, where the graywacke is nearest in contact with the alkali-feldspar granite (plate 2). The samples were collected to determine whether the geochemistry of the sandstone had been appreciably affected by hydrothermal fluids. The analy ses do not indicate any systematic variation of the graywacke's geochemistry with increasing distance from its contact with the alkali-feldspar granite nor does the petrographic character of the sandstone appear to have been affected by the fluids. In particular, the fluorine content of the sandstone does not vary with sample site proximity to the alkali-feldspar granite. Several samples of the Maraghan lithic graywacke collected elsewhere within the ring structure and near greisenized granite are similarly unaffected. The sandstone seems to have been chemically unreactive with and (or) impervious to the magmatic fluids.

\section{PETROGENESIS OF THE IGNEOUS ROCKS}

A set of Harker variation diagrams (fig. 22) indicate that oxide contents vary fairly smoothly from one rock type to the next, which suggests that these rocks are genetically related. Compositional gaps exist among samples of alkaline dacite as well as between the alkaline dacite as a group and the three more evolved components of the complex. Whether these gaps are a function of sampling or represent real compositional discontinuities is unknown. If real, they indicate that the chemical evolution and emplacement of magma was a discontinuous process.

The felsic differentiates of a parental magma of intermediate composition should compose a small percentage of the entire complex. The low volume of alkaline dacite relative to the other components of the complex is problematic but may be a function of its relatively high specific gravity. High specific gravity dictates greater gravitational stability in the source region for melt represented by this rock type. A large volume of primary, unevolved rock may exist below the exposed part of the ring complex and may account for the high apparent ratio of evolved to unevolved rock within the complex.

The composition of the alkaline dacite is similar to compositions documented for chemically primitive members of transitional basalt-pantellerite sequences (Barberi and others, 1975; Zielinski, 1975). This compositional sequence has been identified in both extensional and compressional tectonic environments, and rock sequences such as this are suggested to be derived by differentiation of a basaltic partial melt of the upper mantle (Barberi and others, 1975; Zielinski, 1975). The ternary $A\left(\mathrm{Na}_{2} \mathrm{O}+\mathrm{K}_{2} \mathrm{O}\right), F$ (total iron as $\mathrm{FeO}$ ), and $M(\mathrm{MgO})$ proportions for the samples of the Silsilah ring complex (fig. 23) suggest that the three highly evolved components of the ring complex could have been derived from the alkaline dacite by separation of a large amount of iron oxide minerals from the dacite. The data follow the magnesium-depleted portion of the extreme iron enrichment-depletion trend characteristic of the Skaergaard Intrusion (Wager and Deer, 1939). This observation agrees with the observation that opaque oxides are abundant in the alkaline dacite but are nearly absent in the alkali granite and even rarer in the aplite and alkali-feldspar granite. Petrographic observations and the Harker diagrams further suggest that the early chemical evolution of the magma represented by ringcomplex components was controlled by the fractionation of iron-titanium oxides, apatite, and sodic plagioclase.

The temporal, spatial, tectonic, and alkaline character of the alkaline dacite, the comenditic rocks, and the Silsilah alkali granite suggest that these rocks form a fractionation series. Inasmuch as the molar ratio $(\mathrm{Na}+\mathrm{K}) / \mathrm{Al}$ of sodic plagioclase, a major constituent of the alkaline dacite absent in other components of the complex, is less than 1 , its crystallization and removal from the alkaline dacite melt caused the composition of that liquid to evolve toward a peralkaline composition. Peralkalinity was achieved and facilitated crystallization of soda pyriboles including aegirineaugite, katophorite, and arfvedsonite. The only mafic silicate that the comendite contains is arfvedsonite, end-member soda amphibole. Amphiboles in the less 
peralkaline Silsilah alkali granite contain less $\mathrm{Na}_{2} \mathrm{O}$. The crystallization and removal of the soda pyriboles, with molar $(\mathrm{Na}+\mathrm{K}) / \mathrm{Al}$ ratios much greater than 1 , caused the composition of the remaining silicate liquid to evolve toward a metaluminous to peraluminous composition such as that characteristic of the Hadhir aplite and the Fawwarah alkali-feldspar granite. Similarly, Cawthorn and others (1976) have suggested that peraluminous compositions can be derived from peralkaline compositions by amphibole fractionation.

The Silsilah alkali granite is slightly porphyritic, and accordingly its solidification history probably involved at least some crystallization under noncotectic conditions. Normative compositions of the Silsilah alkali granite plot well below the minima trend; the samples contain more of the ab and or components than experimentally determined minimum melt compositions for low total pressure. These samples are characterized by a nearly constant ab/or ratio, whereas $Q$ displays significant variation. If the ternary proportions of $Q$, $\mathrm{ab}$, and or (fig. 25) in the alkali granite were considered as cotectic compositions, they would indicate crystallization depths in excess of those indicated by field relations and rock textures, which indicate shallow depths of crystallization. The trend of increasing $Q$ displayed by the alkali granite could indicate that noncotectic crystallization of alkali feldspar is responsible for the compositional variation displayed by this pluton. Crystallization and removal of alkali feldspar having a composition like that of the perthite in the alkali granite, namely $\mathrm{ab}_{56} \mathrm{or}_{44}$ (table 6), would cause $Q$ to increase relative to ab and or; this would cause the composition of the remaining liquid to evolve along a trend coincident with that depicted by the alkali granite and comendite and toward the composition of the Hadhir aplite (fig. 25). The most Q-enriched sample of comendite can be considered to approximate the cotectic composition toward which the liquid represented by the alkali granite was evolving. These relations and textural attributes indicate a shallow depth of crystallization. The ternary proportions of an-ab-or (fig. 26) corroborate this hypothesis.

The allotriomorphic and micrographic textures that characterize the Hadhir aplite and the Fawwarah alkalifeldspar granite suggest that the melts represented by these rocks solidified by cotectic crystallization. The Hadhir aplite composition plots slightly below the $100 \mathrm{MPa}$ minimum composition (fig. 25). The Fawwarah alkali-feldspar granite shows considerable compositional variation parallel to and displaced slightly below the minima trend-toward slightly or-enriched, Qdepleted compositions that are appropriate to crystallization in the $\mathrm{P}\left(\mathrm{H}_{2} \mathrm{O}\right)$ range between about 50 and $400 \mathrm{MPa}$. By interpolation, the average composition of the Fawwarah alkali-feldspar granite plots slightly below the minimum melting composition that corresponds to $\mathrm{P}($ total $)=\mathrm{P}\left(\mathrm{H}_{2} \mathrm{O}\right)=$ about $150 \mathrm{MPa}$, which is equal to $4 \mathrm{~km}$ of overburden.

The minimum melting compositions with various amounts of fluorine present are also displayed because the aplite and alkali-feldspar granite contain significant contents of fluorine, and fluorine dramatically affects the phase equilibria in the granite system. It shifts the minimum melting compositions toward ab-enriched compositions (Manning, 1981). Samples of the alkalifeldspar granite that indicate the greatest crystallization depths, based on their normative composition relative to the minimum melting compositions (Winkler and others, 1975), generally contain the highest fluorine concentrations. By interpolation, the average normative composition of the alkali-feldspar granite is coincident for the minimum melt composition that would be obtained for about 0.25 percent fluorine and $P($ Total $)=100$ $\mathrm{MPa}$, or about $3 \mathrm{~km}$ of overburden. This is a maximum depth estimate because the nearby presence of rock greisenized by a fluorine-dominated fluid phase indicates that some fluorine, initially dissolved in the alkalifeldspar granite melt, exsolved and was lost during late magmatic processes. The fluorine content of samples themselves is, therefore, a minimum value for the amount of fluorine dissolved in the melt before a separate fluid phase was exsolved.

The normative compositions of the Silsilah ring complex rocks are also plotted on a normative an-ab-or ternary diagram (fig. 26) to help substantiate inferences derived from consideration of phase relations and rock compositions displayed on the normative $Q$-ab-or diagram (fig. 25). By interpolation of experimental relations (James and Hamilton, 1969; Whitney, 1975), the Silsilah ring complex rocks may be inferred to have crystallized at pressures less than $100 \mathrm{MPa}$ and, therefore, at a depth of less than $3 \mathrm{~km}$.

The presence of the Fe-Li mica zinnwaldite does not require that either the aplite or alkali-feldspar granite has crystallized at high pressure; that is, at great depth or high $\mathrm{P}\left(\mathrm{H}_{2} \mathrm{O}\right)$. Experimental work and thermodynamic considerations (Miller and others, 1981) have demonstrated that the stability of nonideal muscovite extends to lower pressure than that proposed for ideal muscovite (Yoder and Eugster, 1954). The stability of $\mathrm{Fe}-\mathrm{Li}$ micas may similarly extend to lower pressures than that determined for ideal muscovite.

The alkali granite, aplite, and alkali-feldspar granite have trends on the $Q$-ab-or ternary diagram (fig. 25) suggesting their possible cogenesis. As mentioned above, the alkali granite, locally quenched to comendite, may have differentiated by fractionation of alkali feldspar and soda pyriboles. Fractionation may have led to a 
composition like that of the proto-Fawwarah alkalifeldspar granite. The concentration of fluorine dissolved in the melt increased, because fluorine was not removed by liquidus phases, and caused the cotectic composition of the magma to evolve toward more ab-rich compositions (Manning, 1981). A limited amount of noncotectic crystallization ensued and caused the composition of the remaining liquid to evolve toward a cotectic composition commensurate with the increasing fluorine content of the remaining melt. As this process continued, the composition of the melt evolved toward one richer in ab. The composition of samples of the alkalifeldspar granite and the aplite suggest that this process was operative during their crystallization (fig. 25).

Contact relations and grain size indicate that magma represented by the proto-Fawwarah alkali-feldspar granite was emplaced and began to cool slowly. A larger batch of compositionally identical magma was subsequently emplaced. Following emplacement of this magma and possibly as a consequence of the volume expansion that accompanied exsolution of a fluid phase from it, the strength of the host rock was exceeded. With confining pressure greatly reduced, a fluid phase exsolved and escaped from the apical part of the magma. As a consequence, the liquidus temperature of that magma was dramatically lowered, causing pressure quenching (Tuttle and Bowen, 1958) and rapid, disorderly solidification of the affected magma, now represented by the Hadhir aplite. Magma beneath the aplitic carapace continued to evolve by incompatible traceelement enrichment and ultimately solidified to the Fawwarah alkali-feldspar granite. The Fawwarah alkalifeldspar granite was the last igneous component of the ring complex to solidify. It solidified below the coherent and impermeable carapace represented by the Hadhir aplite. Fluids that exsolved from the alkali-feldspar granite as it crystallized were trapped beneath the aplite, in the cupola zone of the crystallizing magma body, and caused late-stage greisenization in the apical part of the pluton.

The layered zone of alternating pegmatite and aplite between the alkali-feldspar granite and the aplite represents crystallization during the repeated accumulation and loss of a volatile phase that occurred after magma represented by the Hadhir aplite was pressure quenched. Nucleation of pegmatite was promoted by accumulation of a fluid phase and terminated when the volume expansion that accompanied fluid exsolution caused renewed fracturing in the country rock. Renewed pressure quenching caused pegmatite pods to be enclosed in a matrix of aplite that resealed the system prior to repetition of the cycle. This process continued until volatile components of the magma were consumed as constituents of volatile-bearing minerals or in the cyclic accumulation-loss process that occurred during the waning stages of solidification.

The existence of a single perthitic feldspar in the alkali granite (discrete grains of plagioclase are not abundant), and of two separately nucleated, nearly end-member alkali feldspars in the Hadhir aplite and Fawwaral alkali-feldspar granite, indicates that the magmas represented by these plutons crystallized under different physicochemical conditions. Tuttle and Bowen (1958) indicated that two independently nucleated alkali feldspars result when crystallization occurs with $\mathrm{P}\left(\mathrm{H}_{2} \mathrm{O}\right)=\mathrm{P}($ total $)=350 \mathrm{MPa}$ in a calcium-free system. The presence of small quantities of calcium and perhaps also the presence of fluorine in significant quantities, such as those encountered in the aplite and alkalifeldspar granite, significantly reduce the pressure requirement. The presence of perthite in the alkali granite and of two alkali feldspars in the aplite and alkalifeldspar granite indicates that the alkali granite crystallized from a liquid that contained significantly less dissolved volatiles than did the magma that solidified to the aplite and alkali-feldspar granite. The elevated fluorine content of the aplite and the alkali-feldspar granite confirms that they crystallized from a silicate liquid that contained a large component of dissolved fluid. The actual percentage of fluid dissolved in the magmas represented by these two plutons is indeterminate because much of it exsolved and became available for postmagmatic greisenization.

Igneous processes that yield a peralkaline liquid favor partitioning of zirconium into the melt phase because alkali-zircono-silicate complexes are stabilized in liquids with an excess of sodium and potassium relative to aluminum (Watson, 1979). Thus, zirconium is concentrated in peralkaline melts during the differentiation process by formation of these complexes but is buffered at $100-200 \mathrm{ppm}$ in nonperalkaline magmas by crystallization of zircon. The extreme enrichment of zirconium in the Silsilalı alkali granite results from the stabilization of alkali-zircono-silicate complexes in the melt and is characteristic of the peralkaline granites of the northeastern Arabian Shield (Stuckless and others, 1982). The high zirconium content of the alkaline dacite may also result from concentration of zirconium in the melt phase by the formation of alkali-zircono-silicate complexes.

The dramatic difference in zirconium content between the alkali granite and both the aplite and alkali-feldspar granite (table 2 ) is probably related to crystallization and removal of a soda-bearing amphibole such as katophorite. As previously indicated, amphibole fractionation can cause a peralkaline magma to evolve to one with a peraluminous composition and, in so doing, will greatly reduce the ability of the magma to stabilize 
alkali-zircono-silicate complexes (Watson, 1979). With the destabilization of these complexes, the magma becomes zirconium saturated and begins to crystallize zircon, which may experience gravitational settling and separation from the magma. This process would drive the zirconium concentration of the magma downward toward the zirconium-buffered concentration of $100-150 \mathrm{ppm}$ suggested by Watson (1979) for nonperalkaline melts. As a silicate liquid evolves from a peralkaline to a peraluminous composition, its zirconium concentration must decrease.

The distribution of rubidium and strontium in the components of the ring complex suggests that alkalifeldspar granite and the aplite could have been derived from the magma represented by the comendite and alkali granite by fractionation of plagioclase and amphibole (Walsh and others, 1979). The relative contents of potassium, rubidium, and strontium (fig. 27) in the various components of the ring complex also suggest that the components are comagmatic. The observation that the chemical evolution of the ring-complex rocks is a systematic function of time is confirmed by the facts that samples of the alkaline dacite, the oldest component of the complex, are strontium enriched; the Silsilah alkali granite, of intermediate age, is potassium enriched; and the Hadhir aplite and Fawwarah alkalifeldspar granite, the youngest components of the complex, are increasingly rubidium enriched (fig. 27).

The contents of rubidium, strontium, and potassium are controlled by their mineral-melt distribution coefficients and the phase equilibria that prevail during crystallization. Primitive magmas are characterized by high concentrations of strontium relative to potassium (Turekian and Wedepohl, 1961). Compositions such as these become increasingly potassium enriched as plagioclase crystallizes and removes strontium from the magma (Hanson, 1978). Rubidium, which acts incompatibly, is preferentially partitioned into silicate liquid so that rocks of intermediate composition contain relatively little more rubidium than the primitive magma from which they are derived. When potassium feldspar nucleates, late in magmatic evolution, potassium begins to be effectively removed from the magma (Hanson, 1978) and the relative concentration of rubidium begins to increase. As this trend continues, a small volume of highly evolved magma with a very high proportion of rubidium to potassium and strontium may result. Rubidium is finally and effectively removed from the magma by crystallization of micas (Hanson, 1978). This differentiation process is depicted by a smooth variation curve on a ternary strontium-potassium-rubidium diagram that begins near the strontium apex, trends toward the potassium apex, and then turns dramatically toward the rubidium apex. Geochemical data for the components of the Silsilah ring complex follow this trend (fig. 27) and suggest that the components are cogenetic and evolved by processes of igneous differentiation. The ternary proportions of strontium, potassium, and rubidium in genetically unrelated plutons do not produce continuous, systematic trends of this type.

The barium content of the Silsilah ring complex components further substantiates their proposed cogenesis and suggests that the alkali-feldspar granite and the aplite represent a very small part of the primitive, parental magma. Mineral-melt distribution coefficients for barium are highest in biotite and potassium feldspar, although plagioclase crystallization can also reduce the barium content of a melt (Hanson, 1978). High barium content characteristic of the alkaline dacite suggests that a phase such as potassium feldspar or biotite was part of the partial melt assemblage. The dramatic and steady decrease of barium, from the oldest component of the complex to the youngest, demonstrates the evolution of the magma toward barium-depleted compositions by crystallization and removal of alkali feldspar from the magmas represented by the alkaline dacite, comendite, and alkali granite and by crystallization and removal of micas from the magma represented by the aplite and alkali-feldspar granite. The extremely low barium content of the complex's youngest component, relative to its content in the oldest component, indicates that the youngest represents a very small proportion of the oldest.

The REE content and chondrite-normalized patterns also provide some insight to the genesis of the ring complex components. The lack of a europium anomaly in the alkaline dacite suggests that these rocks represent primary liquids which have undergone little, if any, differentiation. The patterns for the alkali granite and comendite, the peralkaline rocks, are approximately parallel to those for the samples of the alkaline dacite. The overall REE content of the peralkaline rocks is higher than in the alkaline dacite, and the peralkaline rocks are characterized by a moderate, negative europium anomaly.

Plagioclase and opaque oxides are major components of the alkaline dacite but are almost absent in the other components. Their near absence indicates that they were removed from the silicate liquid, perhaps by filter pressing or crystal settling. Except for europium in plagioclase, the REE have mineral-melt distribution coefficients that are less than 1 in both plagioclase and the opaque oxides (Hanson, 1978). Consequently, crystallization and removal of opaque oxides and plagioclase from the alkaline dacite did not cause REE fractionation, but their removal led to the overall REE enrichment observed in the alkali granite, which represents the silicate liquid from which they were removed. The 
removal of plagioclase did cause a negative europium anomaly as a consequence of europium's substitution for calcium in the mineral lattice.

Derivation of the chondrite-normalized REE patterns that typify the alkali-feldspar granite and the aplite from the patterns characteristic of the peralkaline rocks is achieved by additional crystal fractionation. As indicated by the total REE content of these rocks (table 2), the tendency for the REE to act incompatibly and to be enriched in residual magmas was more than balanced by their removal in the minerals crystallizing from the magma represented by the alkali granite. Relative to the alkali granite, REE patterns for the aplite and alkali feldspar granite are flattened and characterized by much larger, negative europium anomalies.

The REE distribution coefficients in alkali feldspar (Hanson, 1978; Drexler and others, 1983) are such that its crystallization and removal would cause the magnitude of the negative europium anomaly to increase and would cause the overall REE content of the remaining liquid to increase. As the REE mineral-melt distribution coefficients in alkali feldspar are greater for the light REE (LREE) than for the heavy REE (HREE), the HREE will become more enriched in the remaining silicate liquid than the LREE. The result is that the HREE are more abundant in the alkali-feldspar granite and the aplite than in the alkali granite. Zircon removed from the alkali granite during the differentiation of the magma represented by that pluton could have caused the HREE to have been depleted relative to the LREE and may have somewhat mitigated the tendency toward HREE enrichment arising from alkali feldspar fractionation.

LREE enrichment predicted by alkali feldspar fractionation was probably counteracted by two processes. Miller and Mittlefehldt (1982) suggest that the crystallization and removal of LREE-enriched accessory phases such as monazite, sphene, or allanite may be responsible for LREE depletion in highly evolved igneous rocks. Experimental work and thermodynamic calculations (Candela, 1984) demonstrate that cerium is more strongly partitioned into evolving magmatic aqueous fluid than lutecium. Thus, LREE depletion observed for the alkali-feldspar granite and aplite may result from the combined effects of their incorporation in LREE-enriched accessory phases and partitioning into a vapor phase that separated from the crystallizing magma system.

The ab content of coexisting plagioclase and alkali feldspar (table 5) indicates that the feldspars in the alkali-feldspar granite equilibrated (Whitney and Stormer, 1977) in the temperature range between about $350^{\circ} \mathrm{C}$ and $450^{\circ} \mathrm{C}$ (fig. 35). This temperature range is

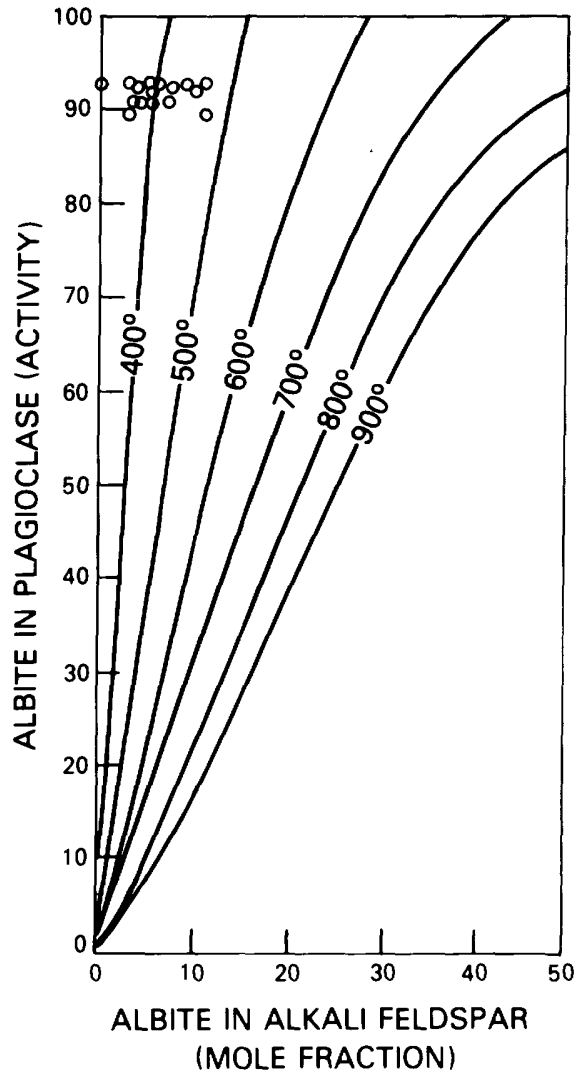

Figure 35. Plot (after Whitney and Stormer, 1977) showing the distribution of ab between coexisting plagioclase and potassium feldspar in four samples of the Fawwarah alkali-feldspar granite. Each plotted point represents data for one of the plagioclase-potassium feldspar grain pairs listed in table 5 .

well below that at which even a fluorine-fluxed silicate liquid can exist. Preliminary experimental work by Manning (1981) suggests that fluorine-rich silicate liquid of a particular composition may be stable at temperatures as low as $550^{\circ} \mathrm{C}$. The low temperatures suggested by feldspar geothermometry indicate that these feldspars continued equilibration in the subsolidus to the temperatures indicated. The low-temperature equilibration may have been facilitated by circulation of a postmagmatic hydrothermal fluid.

Delta ${ }^{18} \mathrm{O}$ values for quartz from granitoid rocks are generally $1.5-2.0 \%$ larger than corresponding wholerock values (Taylor, 1968). The delta ${ }^{18} \mathrm{O}$ fractionation for quartz-whole rock pairs from the highly evolved components of the complex is small, reversed in one case, and apparently consistent with a crystallization temperature greater than $700^{\circ} \mathrm{C}$ (Mark Barton, written commun., 1983). However, experimental work (Manning, 1981) indicates that granite minimum-melt 
temperatures are much lower and vary from $630^{\circ} \mathrm{C}$ to $690^{\circ} \mathrm{C}$, with 4 to 1 percent fluorine at $100 \mathrm{MPa}$ and excess water. The small, observed delta ${ }^{18} \mathrm{O}$ quartz-whole rock fractionation values, and the reversal, may indicate that the primary delta ${ }^{18} \mathrm{O}$ of potassium feldspar, the constituent of these rocks most susceptible to reaction with circulating fluids, was slightly elevated by reaction and reequilibration with ${ }^{18} \mathrm{O}$-enriched meteoric water (O'Neil and others, 1977). The implied reaction of potassium feldspar with a postmagmatic fluid is substantiated by low-equilibration temperatures given by feldspar geothermometry and the mottled, weakly altered appearance of these grains.

The observed delta ${ }^{18} \mathrm{O}$ values for the samples that represent the components of the Silsilah ring complex, especially values for the alkali-feldspar granite and the aplite, are relatively heavy, compared to values determined for most granites, and suggest the involvement of continental material in their genesis (O'Neil and others, 1977). The fact that the value for the Silsilal alkali granite is slightly lower than values for the other units is probably a function of crystallization at higher, noncotectic temperatures than the aplite or the alkalifeldspar granite and of consequent equilibration with slightly less delta ${ }^{18} \mathrm{O}$-enriched magma. Anomalously high contents of the incompatible trace elements in the ring-complex rocks also necessitate a continental component in their genesis. Lead-isotopic data preclude involvement of continental material more than $100 \mathrm{Ma}$ older than the complex itself. The rocks of the Silsilah ring complex may be the composite of an upper mantle melt that caused partial melting of and combined with material from the incipiently cratonized arc complex that is hypothesized (du Bray, 1983b) to have existed in the northeast Arabian Shield during the 100-Ma period that preceded emplacement of the Silsilall ring complex. The oxygen isotopic composition of the ring complex rocks may have been derived by partial melting involving a component of aluminous volcanogenic sediments within the arc complex, and the relatively nonradiogenic lead composition of the ring complex components would have been inherited from these juvenile sediments and associated igneous rocks that formed the arc.

The temporal, spatial, and tectonic association of the Silsilah ring complex components suggest that these rocks are cogenetic. The similar isotopic compositions (tables 4 and 8, fig. 30) of the Fawwarall alkali-feldspar granite, Hadhir aplite, and the Silsilah alkali granite substantiate the hypothesis that the magmas represented by these units had the same protolith and that neither includes an exotic component derived by interaction with wallrock. Magmas represented by the evolved, felsic components of the complex evolved by mineral fractionation from the primitive components of the complex. Thus, the components of the Silsilall ring complex represent samples of magma that depict the successive chemical evolution of a large magma chamber. As such, the chemical variation portrayed by components of the complex would be a consequence of a discontinuous process that involved magma evolution via separation of silicate liquid from earlier formed crystals and emplacement of batches of magmas whose compositions represent stages of the parent magma's chemical evolution.

\section{PETROGENESIS OF THE MINERALIZED ROCKS}

The two main types of greisen associated with rocks of the ring complex represent complete and incomplete greisenization of the Fawwarah alkali-feldspar granite. Primary igneous textures have been obliterated in the complete greisen. Igneous textures characteristic of the Fawwarah alkali-feldspar granite are distinctly preserved in the weakly mineralized, incomplete greisen and in argillically altered rock associated with the complete greisen, and they indicate that the greisens are composed of hydrothermally altered alkali-feldspar granite. The mineral assemblages that characterize each of the greisen types reflect the degree to which the protolith was hydrothermally altered during the greisenization process. Textural features and mineral assemblages like those of the Fawwarah alkali-feldspar granite grade into textures and mineralogies characteristic of complete greisen.

Well-developed, depth-dependent zonation of the greisens suggests that strong physicochemical gradients prevailed during the greisenization process. The observed zonation is consistent with the roofward accumulation of a late-stage hydrothermal fluid and its dissolved constituents. Greisenization was most intense at the top of the hydrothermal system, immediately beneath the Hadhir aplite, where the hydrothermal fluid was concentrated. The fluid accumulation process was less effective with increasing depth, and greisenization was correspondingly less intense.

The cyclic accumulation and loss of a volatile phase was precluded where cooling magma represented by the Fawwarah alkali-feldspar granite was effectively enclosed by a carapace of aplite and country rock. The fluid phase and its dissolved constituents accumulated and became available for greisenization in areas where confinement was effective. Thick accumulations of layered pegmatite in an aplite matrix, such as those found in the ring, may indicate areas in which an aqueous phase and its dissolved constituents, including 
Sn, were ineffectively contained and cyclically accumulated and escaped along fractures into now-missing country rock. In these areas, thick accumulations of aplite and pegmatite evolved as a consequence of repeated episodes of pressure quenching in response to confinement rupture. Small thicknesses of pegmatite and aplite, such as those found immediately above intensely mineralized greisen, may indicate areas in which the volatile phase was effectively contained. Thin accumulations of aplite and pegmatite in these areas is a consequence of a limited number of confinement rupture and pressure-quenching episodes. Thin accumulations such as these may occur above intensely mineralized cupolas of greisenized alkali-feldspar granite.

The genesis of the mineralized rocks, and in particular the quartz-cassiterite-topaz greisens and the wolframitebearing quartz veins, are only partly understood. The nearly complete separation of high-grade accumulations of cassiterite in greisens from high-grade but erratic accumulations of wolframite in quartz veins suggests that a large, strongly zoned hydrothermal system once existed in the southwest part of the ring complex or that several hydrothermal systems, in part overlapping, evolved in the same area.

The Fawwarah alkali-feldspar granite contains a highly anomalous quantity of Sn (table 2) so that it, and not the graywacke, is the likely source of the tin that was concentrated in the deposit. Tin probably acted as an incompatible element during crystallization and its concentration in the melt phase increased progressively. Tin may be transported and concentrated as a complex with F (Bailey, 1977), although experimental evidence indicates that $F$ and Sn may simply be cotravellers in highly evolved silicate and hydrothermal liquids (Stemprok, 1982). Tin was ultimately partitioned into a F-rich fluid phase that exsolved as the Fawwarah alkali-feldspar granite crystallized, although a small proportion was partitioned into zinnwaldite. This fluid phase was trapped below the competent and impermeable Hadhir aplite and caused recrystallization of the alkali-feldspar granite in its roof zone. The physicochemical conditions that caused and localized greisenization and conversion of alkali-feldspar granite to intensely mineralized quartz-cassiterite-topaz rock are unknown. Mineralization may have been localized by faults or in fractures that developed as the alkalifeldspar granite cooled and contracted, although evidence of structural control is absent. Similarly, weakly mineralized greisen within the alkali-feldspar may be structurally controlled.

The results of experiments in the granite- $\mathrm{NaF}-\mathrm{SnO}_{2}$ system (Stemprok, 1982) indicate that two immiscible liquids, one silicate-dominated and the other fluoridedominated, evolved under conditions appropriate to magmatic and hydrothermal processes. Tin is almost exclusively partitioned into the silicate liquid. The podlike accumulations of cassiterite in the greisens may represent the immiscible unmixing of silicate and fluoride liquids during the greisenization process and the concomitant partitioning of $\mathrm{Sn}$ into the former.

\section{CONGLUSIONS AND RECOMMENDATIONS}

A greisen tin deposit is associated with the Fawwarah alkali-feldspar granite that forms part of the ring complex at Jabal as Silsilah. The petrologic and geochemical characteristics of the alkali-feldspar granite are like those of granites located elsewhere in the world that also are associated with deposits of $\mathrm{Sn}, \mathrm{W}$, and rare metals. The alkali-feldspar granite is peraluminous, incompatible trace-element enriched, and characterized by a flat chondrite-normalized REE pattern with a very large, negative europium anomaly. The mineralogy of the alkali-feldspar granite is also distinctive because it includes zinnwaldite and topaz.

Differentiation and mineral fractionation controlled magma evolution as components of the ring complex were sequentially emplaced. The Fawwarah alkalifeldspar granite and its quenched equivalent, the Hadhir aplite, were derived from the Silsilah alkali granite which, in turn, was derived from magma represented by the alkaline dacite. Separation of opaque oxides and plagioclase from the geochemically primitive alkaline dacite magma caused the remaining melt to evolve toward a composition represented by the Silsilah alkali granite and its quenched comenditic equivalent. The crystallization and separation of alkali feldspar, soda pyriboles, zircon, and apatite then caused the remaining liquid to evolve to a composition represented by the Fawwarah alkali-feldspar granite and the Hadhir aplite.

Evolution of the ring complex and its associated tin deposit concluded with local, intense hydrothermal alteration of the Fawwarah alkali-feldspar granite to a cassiterite-bearing greisen. The alteration was achieved by a late-stage, hydrothermal fluid that was probably fluorine dominated. The fluid was locally trapped in cupolas beneath the impermeable carapace formed by the Hadhir aplite. The effect of the fluid was to convert the alkali-feldspar granite to an assemblage of quartz, topaz, and cassiterite. Elliptically shaped, high-grade accumulations of cassiterite may owe their existence to the evolution of a second, immiscible fluid phase. Two sets of quartz-wolframite veins associated with the ring complex were also identified. The relationship of the wolframite mineralization to the cassiterite mineralization is unknown, but a genetic link between the two types of mineralization probably exists. 
The ultimate goal of further study, in addition to a determination of the deposit's resource potential, should be to build an ore genesis model that is consistent with all data. Considerable additional work is necessary. Additional, very large scale geologic mapping of the greisens must be completed as a base for all additional work. Detailed wadi sediment sampling should demonstrate the existence of any previously unidentified greisens associated with the ring complex and would provide valuable information concerning the dispersion train of cassiterite in an extremely arid environment. Diamond-core drilling would provide critical information concerning the geometric relations between phases of the greisens and their host rocks.

Additional analytical work, including detailed mineralogic investigations, fluid-inclusion studies, and stableisotopic analyses, will be necessary. Identification of minor accessory phases and study of their trace-element contents will provide information concerning the partitioning and geochemical behavior of trace elements during the hydrothermal processes that caused evolution of the greisens and associated mineralization. In particular, determination should be possible of the chemical composition and, therefore, the approximate metalbearing capacity of the alteration fluids, the temperatures and pressures that prevailed during mineralization, the degree to which the mineralizing fluids were derived from the melts themselves or included a significant component of meteoric water derived from the host Maraghan lithic graywacke, and whether the hydrothermal process was multi-stage should be made.

The study has demonstrated that greisenization occurred at the top of the alkali-feldspar granite, adjacent to its subhorizontal contact with the Hadhir aplite. The Hadhir aplite, in turn, forms a subhorizontal sheet beneath the host graywacke. Hydrothermally altered rock and numerous greisens in the southwest part of the complex, the latter emergent through small thicknesses of graywacke and aplite, suggest that the potential for additional tin-mineralized greisen located beneath graywacke and aplite is high throughout this part of the ring complex.

The discovery of a tin deposit at Jabal as Silsilah is encouraging and suggests that similar deposits of this type could occur within the Arabian Shield. The Silsilah tin deposit provides an excellent opportunity for further study and petrogenetic modeling of this deposit type. Detailed study of the deposit and its setting may facilitate identification of criteria that will enhance the ability to identify plutons with similar mineral potential.

\section{REFERENGES GITED}

Allen, M., Tidball, R., Samater, R., Selner, G. I., 1983, Interpretation of geochemical data from panned concentrates of wadi sediments using R-mode factor analysis, Jabal Hibshi quadrangle (26F), Kingdom of Saudi Arabia: Saudi Arabian Deputy Ministry for Mineral Resources Data File USGS-DF-03-9, 55 p.

Bailey, J. C., 1977, Fluorine in granitic rocks and melts: a review: Chemical Geology, v. 19, p. 1-42.

Barberi, F., Ferrara, G., Santacroce, R., Treuil, M., and Varet, J., 1975, A transitional basalt-pantellerite sequence of fractional crystallization, Boina centre (Afar Rift, Ethiopia): Journal of Petrology, vol. 16 , p. $22-56$.

Bence, A. E., and Albee, A. L., 1968, Empirical correction factors for the electron microanalysis of silicates and oxides: Journal of Geology, v. 76, p. 382-403.

Bowden, P., and Turner, D. C., 1974, Peralkaline and associated ring complexes in the Nigeria-Niger province, West Africa, in Sorenson, H., ed., The alkaline rocks: New York, John Wiley, p. 330-351.

Burt, Donald, M., Sheridan, Michael, F., Bikun, James, V., and Christiansen, Eric, H., 1982, Topaz rhyolites-distribution, origin, and significance for exploration: Economic Geology, v. 77, p. $1818-1836$.

Candela, P. A., 1984, A partitioning model for the rare earth elements and other polyvalent, chloride-complexed metals in melt-vapor systems: Geological Society of America Abstracts with Prograns, v. 16 , no. 6, p. 462 .

Cawthorn, R. G., Strong, D. F., and Brown, P. A., 1976, Origin of corundum-normative intrusive and extrusive magmas: Nature, $v$. 259, p. 102-104.

Chappell, B. W., and White, A. J. R., 1974, Two contrasting granite types: Pacific Geology, v. 8, p. 173-174.

Cole, J. C., Smith, C. W., and Fenton, M. D., 1981, Preliminary investigation of the Baid al Jimalah tungsten deposit, Kingdom of Saudi Arabia: U.S. Geological Survey Technical Record 20 (Interagency Report 377), 26 p.

Collins, W. J., Beams, S. D., White, A. J. R., and Chappell, B. W., 1982, Nature and origin of A-type granites with particular reference to southeastern Australia: Contributions to Mineralogy and Petrology, v. 80, p. 189-200.

Deer, W. A., Howie, R. A., and Zussman, J., 1962, Rock forming minerals: London, Longman, v. 3, 270 p.

1966, An introduction to the rock forming minerals: London, Longmans, Green, and Co., $528 \mathrm{p}$.

Drexler, J. W., Bornhorst, T. J., and Noble, D. C., 1983, Trace element sanidine/glass distribution coefficients for peralkaline silicic rocks and their implications to peralkaline petrogenesis: Lithos, v. 16, p. $265-271$.

du Bray, E. A., 1983a, Petrology of muscovite-bearing granitoids in the eastern and southeastern Arabian Shield, Kingdom of Saudi Arabia: Saudi Arabian Deputy Ministry for Mineral Resources Open-File Report USGS-OF-03-10, 36 p.

1983b, Reconnaissance geology of the Jabal as Silsilalı quadrangle, sheet 26/42 D, Kingdom of Saudi Arabia: Saudi Arabian Deputy Ministry for Mineral Resources Technical Record USGS-TR-03-4, 52 p., scale 1:100,000.

$1983 \mathrm{c}$, Geochemical results and sample locality maps for the Silsilalı tin prospect: Saudi Arabian Deputy Ministry for Mineral Resources Data File USGS-DF-03-15.

du Bray, E. A., Elliott, J. E., and Stoeser, D. B., 1982, Geochemical evaluation of felsic plutonic rocks in the eastern and southeastern Arabian Shield, Kingdom of Saudi Arabia: Saudi Arabian Deputy Ministry for Mineral Resources Technical Record USGSTR-02-2, 53 p.

du Bray, E. A., Smith, C. W., Samater, R. M., 1984, Result of grid sampling and large-scale geologic mapping, Silsilalı tin deposit, Kingdom of Saudi Arabia: Saudi Arabian Deputy Ministry for Mineral Resources Open-File Report USGS-OF-04-47, 41 p. 
Dudykina, A. S., 1959, Paragenetic associations of element admixtures in cassiterite of different genetic types of tin ore deposits: Trudy Instituta Geologii Rudnykh Mestorozhdenii, Petrografii, Mineralogii, i Geokhimii, Akademiya Nauk SSSR, v. 28, p. 111-121.

Elliott, J. E., 1980, Tin-bearing granite of Jabal al Gaharra in the southern Arabian Shield, Kingdom of Saudi Arabia: U.S. Geological Survey Saudi Arabian Mission Technical Record 4, $28 \mathrm{p}$.

Flanigan, V. J., and Zablocki, C. J., 1983, An evaluation of the applicability of the telluric-electric and audio-magnetotelluric methods to mineral assessment on the Arabian Shield, Kingdom of Saudi Arabia: Saudi Arabian Deputy Ministry for Mineral Resources Open-File Report USGS-OF-04-26, 61 p.

Hanson, G. N., 1978, The application of trace elements to the petrogenesis of igneous rocks of granitic composition: Earth and Planetary Science Letters, v. 38, p. 26-43.

Irvine T. N., and Baragar, W. R. A., 1971, A guide to the chemical classification of the common volcanic rocks: Canadian Journal of Earth Sciences, v. 8, p. 523-548.

Ishihara, Shunso, 1977, Magnetite-series and ilmenite-series granitic rocks: Mining Geology, v. 27, p. 293-305.

James, R. S., and Hamilton, D. L., 1969, Phase relations in the system $\mathrm{NaAlSi}{ }_{3} \mathrm{O}_{8}-\mathrm{KAlSi}_{3} \mathrm{O}_{8}-\mathrm{CaAl}_{2} \mathrm{Si}_{2} \mathrm{O}_{8}-\mathrm{SiO}_{2}$ at 1 kilobar water vapor pressure: Contributions to Mineralogy and Petrology, v. 21, p. 111-141.

Ludwig, K. R., 1980, Calculations of uncertainties of U-Pb isotopic data: Earth and Planetary Science Letters, v. 46, p. 212-220.

MacDonald, R., 1975, Nomenclature and petrochemistry of the peralkaline oversaturated extrusive rocks: Bulletin of Volcanology, v. 38, p. $498-516$.

Manning, D. A. C., 1981, The effect of fluorine on liquidus phase relationships in the system Qz-Ab-Or with excess water at $1 \mathrm{~kb}$ : Contributions to Mineralogy and Petrology, v. 76, p. 206-215.

Miesch, A. T., 1980, Scaling variables and interpretation of eigen values in principal component analysis of geologic data: Mathematical Geology, v. 12 , no. 6 , p. 523-538.

Miller, C. F., and Mittlefehldt, D. W., 1982, Depletion of light rareearth elements in felsic magmas: Geology, v. 10, p. 129-133.

Miller, C. F., Stoddard, E. F., Bradfish, L. J., and Dolasse, W. A., 1981, The composition of plutonic muscovite: genetic implications: Canadian Mineralogist, v. 19, p. 25-34.

Noble, D. C., 1968, Systematic variation of major elements in comendite and pantellerite glasses: Earth and Planetary Science Letters, v. 4 , p. $167-172$.

O'Neil, J. R., Shaw, S. E., and Flood, R. H., 1977, Oxygen and hydrogen compositions as indicators of granite genesis in the New England batholith, Austraha: Contributions to Mineralogy and Petrology, v. 62, p. 313-328.

Shand, S. J., 1951, Eruptive rocks: New York, John Wiley, 488 p.

Smith, R. L., and Bailey, R. A., 1968, Resurgent cauldrons in Studies in Volcanology, Geological Society of America Memoir 116, p. 613-662.

Stacey, J. S., Doe, B. R., Roberts, R. J., Delevaux, M. H., and Gramlich, J. W., 1980, A lead isotope study of mineralization in the Saudi Arabian Shield: Contributions to Mineralogy and Petrology, v. 74 , p. $175-188$.

Stacey, J. S., and Kramers, J. D., 1975, Approximation of lead isotope evolution by a two-stage model: Earth and Planetary Science Letters, v. 26, p. 207-221.

Stacey, J. S., and Stoeser, D. B., 1983, Distribution of oceanic and continental leads in the Arabian-Nubian Shield: Contributions to Mineralogy and Petrology, v. 84, p. 91-105.

Stacey, J. S., Stoeser, D. B., Greenwood, W. R., and Fischer, L. B., $1984, \mathrm{U} / \mathrm{Pb}$ zircon geochronolgy and geologic evolution of the Halaban-Al Amar region of the eastern Arabian Shield, Kingdom of Saudi Arabia: Saudi Arabian Deputy Ministry for Mineral Resources Open-File Report USGS-OF-04-30, 37 p.
Stemprok, Miroslav, 1982, Tin-fluorine relationships in ore-bearing assemblages in Evans, A. M., ed., Metallization Associated with Acid Magmatism, v. 6, New York, John Wiley p. 321-337.

Stoeser, D. B., and Elliott, J. E., 1980, Postorogenic peralkahine and calc-alkahine granites and associated minerahization of the Arabian Shield, Kingdom of Saudi Arabia, in Evolution and mineralization of the Arabian-Nubian Shield: King Abdulaziz University, Institute of Applied Geology Bulletin 3, v. 4, OxfordNew York, Pergamon Press, p. 1-23.

Streckeisen, Albert, 1976, To each plutonic rock its proper name: Earth-Science Reviews, v. 12, p. 1-33.

Stuckless, J. S., Hedge, C. E., Wenner, D. B., and Nkomo, I. T., 1984, Isotopic studies of postorogenic granites from the northeastern Arabian Shield, Kingdom of Saudi Arabia: Saudi Arabian Deputy Ministry for Mineral Resources Open-File Report USGSOF-04-42, 40 p.

Stuckless, J. S., Knight, R. J., VanTrump, G., Jr., and Budahn, J. R., 1982, Trace-element geochemistry of postorogenic granites from the northeastern Arabian Shield, Kingdom of Saudi Arabia: Saudi Arabian Deputy Ministry for Mineral Resources Open-File Report USGS-OF-02-91, $34 \mathrm{p}$.

Taylor, H. P., Jr., 1968, The oxygen isotope geochemistry of igneous rocks: Contributions to Mineralogy and Petrology, v. 19, p. 1-71.

Tischendorf, G., 1977, Geochemical and petrographic characteristics of silicic magmatic rocks associated with rare-element mineralization, in Metallization associated with acid magmatism: Czechoslovakia Geological Survey, Prague, v. 2, p. 41-96.

Turekian, K. K., and Wedepohl, K. H., 1961, Distribution of the elements in some major units of the earth's crust: Geological Society of America Bulletin, v. 72, no. 2, p. 175-192.

Tuttle, O. F., and Bowen, N. L., 1958, Origin of granite in the light of experimental studies in the system $\mathrm{NaAlSi}_{3} \mathrm{O}_{8}-\mathrm{KAlSi}_{3} \mathrm{O}_{8}-\mathrm{SiO}_{2}-$ $\mathrm{H}_{2} \mathrm{O}$ : Geological Society of America Memoir 74, $152 \mathrm{p}$.

Wager, L. R., and Deer, W. A., 1939, Geological investigations in East Greenland, Part III: The petrology of the Skaergaard Intrusion, Kangerdlugssuag, East Greenland: Medd. Groenland, 105, no. 4, p. 1-352.

Walsh, J. N., Beckinsdale, R. D., Skelhorn, R. R., and Thorpe, R. S., 1979, Geochemistry and petrogenesis of Tertiary granitic rocks from the island of Mull, northwest Scotland: Contributions to Mineralogy and Petrology, v. 71, p. 99-166.

Watson, E. B., 1979, Zircon saturation in felsic liquids: Experimental results and application to trace element geochemistry: Contributions to Mineralogy and Petrology, v. 70. p. 407-419.

White, A. J. R., and Chappell, B. W., 1977, Ultrametamorphism and granitoid genesis: Tectonophysics, v. 43, p. 7-22.

Whitney, J. A., 1975, The effects of pressure, temperature, and $\mathrm{X}\left(\mathrm{H}_{2} \mathrm{O}\right)$ on phase assemblages in four synthetic rock compositions: Journal of Geology, v. 83, p. 1-31.

Whitney, J. A., and Stormer, J. C. Jr., 1977, The distribution of $\mathrm{NaAlSi}{ }_{3} \mathrm{O}_{8}$ between coexisting microcline and plagioclase and its effect on geothermometric calculations: American Mineralogist, v. 62 , p. $687-691$

Whitney, J. W., 1983, Erosional history and surficial geology of western Saudi Arabia: Saudi Arabian Deputy Ministry for Mineral Resources Technical Record USGS-TR-04-1, 90 p.

Williams, Howel, Turner, F. J., and Gilbert, C. M., 1954, Petrography: An introduction to the study of rocks in thin sections: San Francisco, Freeman, $406 \mathrm{p}$.

Winkler, H. G. F., Boese, M., and Marcopoulos, T., 1975, Low temperature granitic melts: Neues Jahrbuch fuer Mineralogie, Monatshefte, v. 6 , p. $245-268$

Yoder, H. S., and Eugster, H. P., 1954, Phlogopite synthesis and stability range: Geochimica et Cosmochimica Acta, v. 6, p. 157-185.

Zielinski, R. A., 1975, Trace element evaluation of a suite of rocks from Reunion Island, Indian Ocean: Geochimica et Cosmochimica Acta, v. 39 , p. $713-734$. 